\title{
41. JURASSIC SEDIMENTATION HISTORY OF SITE 534 (WESTERN NORTH ATLANTIC) AND OF THE ATLANTIC-TETHYS SEAWAY 1
}

\author{
James G. Ogg, ${ }^{2}$ Department of Geology and Geophysics, University of Wyoming, Laramie, Wyoming \\ Alastair H. F. Robertson, Grant Institute of Geology, University of Edinburgh, West Mains Road, \\ Edinburgh EH9 3JW, United Kingdom \\ and
}

Lubomir F. Jansa, Atlantic Geoscience Centre, Geological Survey of Canada, Bedford Institute of Oceanography, Dartmouth, Nova Scotia B2Y 4A2, Canada

\begin{abstract}
Site 534 reflects a complex interplay of global, basinal, and local influences on sedimentation during the Callovian and Late Jurassic. Rifting and rapid subsidence of the continental margins of the North Atlantic-Tethys seaway occurred during the late Early Jurassic (Sinemurian-Pliensbachian), but rapid spreading between the North American margin (Blake Spur Ridge and magnetic lineation) and the northwest African margin did not commence until the Bathonian or earliest Callovian.

Site 534, drilled on marine magnetic anomaly "M-28" of Bryan et al. (1980), was initially about $150 \mathrm{~km}$ from either continental margin. The ?middle Callovian basal sediments are dusky red silty marl. Callovían transgression led to active carbonate platforms on the margin, recorded at Site 534 as a rise in the CCD (carbonate compensation depth), then arrival of lime-rich turbidites from the Blake Plateau platform across the Blake Spur Ridge. The host pelagic sediment is greenish black, organic-rich, radiolarian-rich, silty claystone. Hydrothermal activity on the nearby spreading ridge enriched this lower unit in metals. In the Oxfordian, the input of terrestrial silt rapidly diminished; radiolarians or other bioclasts were not preserved. The dark variegated claystone has fine-grained marl and reddish claystone turbidite beds. The late Callovian-Oxfordian Western Tethys has radiolarian chert deposition, marine hiatuses, or organic-rich sediments.

The Kimmeridgian and Tithonian had a stable or receding sea level. Near the end of the Jurassic many of the carbonate platforms of the margins were buried beneath prograding fan or alluvial deposits. Carbonate deposition shifted to the deep sea. Site 534 records the deepening of the CCD and ACD (aragonite compensation depth) during the Kimmeridgian and early Tithonian, then a rise of the ACD in the middle Tithonian. Similar trends occurred throughout the Western Tethys-Atlantic. High nannofossil productivity of the seaway led to deposition of very widespread white micritic limestone in the late Tithonian-Berriasian. The underlying sediment had a slower deposition rate of carbonate, therefore its higher clay and associated Fe content produced a red marl. A short sea-level incursion occurred on the Atlantic margins during the Kimmeridgian and is reflected in the Site 534 greenish gray marl unit by numerous turbidite beds of shallow-water carbonates.
\end{abstract}

\section{INTRODUCTION}

The early history of the Atlantic-Tethys ocean system has been debated ever since Wegener proposed the theory of continental drift. At DSDP Site 534 in the western North Atlantic, a thick Jurassic sediment sequence was recovered above oceanic basalt crust. Callovian through Tithonian calcareous claystone and limestone exist as several distinct facies that reflect changes in pelagic sedimentation and paleoceanography during the Jurassic as the Atlantic-Tethys seaway opened and sea levels fluctuated.

In this chapter we examine the record of late Middle and Late Jurassic sedimentation of the Atlantic, then relate it to the evolution of the Atlantic-Tethys ocean system and of pelagic sedimentation. Part One is a detailed description and interpretation of the Jurassic sediment features, petrography, and chemistry of Site 534. Part Two is a comparison of this site with other Atlantic DSDP sites at which Jurassic sediments have been recov-

\footnotetext{
${ }^{1}$ Sheridan, R. E., Gradstein, F. M., et al., Init. Repts. DSDP, 76: Washington (U.S. Govt, Printing Office).

2 Present address: Geological Research Division, A-012, Scripps Institution of Oceanog. raphy, University of California at San Diego, La Jolla, California.
}

ered, plus a summary of Jurassic sedimentation on the Atlantic margins. Part Three is a synthesis of the tectonic evolution and sedimentation of the Western and Eastern Tethys ocean basins. Part Four ties the evolution of these oceans together and discusses possible paleoceanographic scenarios.

\section{PART ONE-JURASSIC SEDIMENTS OF SITE 534}

\section{Regional Setting}

Site $534\left(28.34^{\circ} \mathrm{N}, 75.38^{\circ} \mathrm{W}\right)$ is located in the BlakeBahama Basin about $220 \mathrm{~km}$ north-northeast of the edge of the Bahama Banks (Fig. 1). The site was drilled on a small rise at a present water depth of $4971 \mathrm{~m}$.

The location is $22 \mathrm{~km}$ northeast of Site 391 ; the two sites are on opposite sides of a Mesozoic trough (fracture zone?), as seen on seismic reflection profiles (Sheridan et al., this volume). Site 534 was drilled slightly below the crest of a basement high on the northern flank of the trough, on a slope that is interpreted as a series of small fault blocks (Fig. 2).

This region is called the Outer Jurassic Magnetic Quiet Zone because of the lack of high-amplitude linear magnetic anomalies between M-25 $(370 \mathrm{~km}$ to the east; 


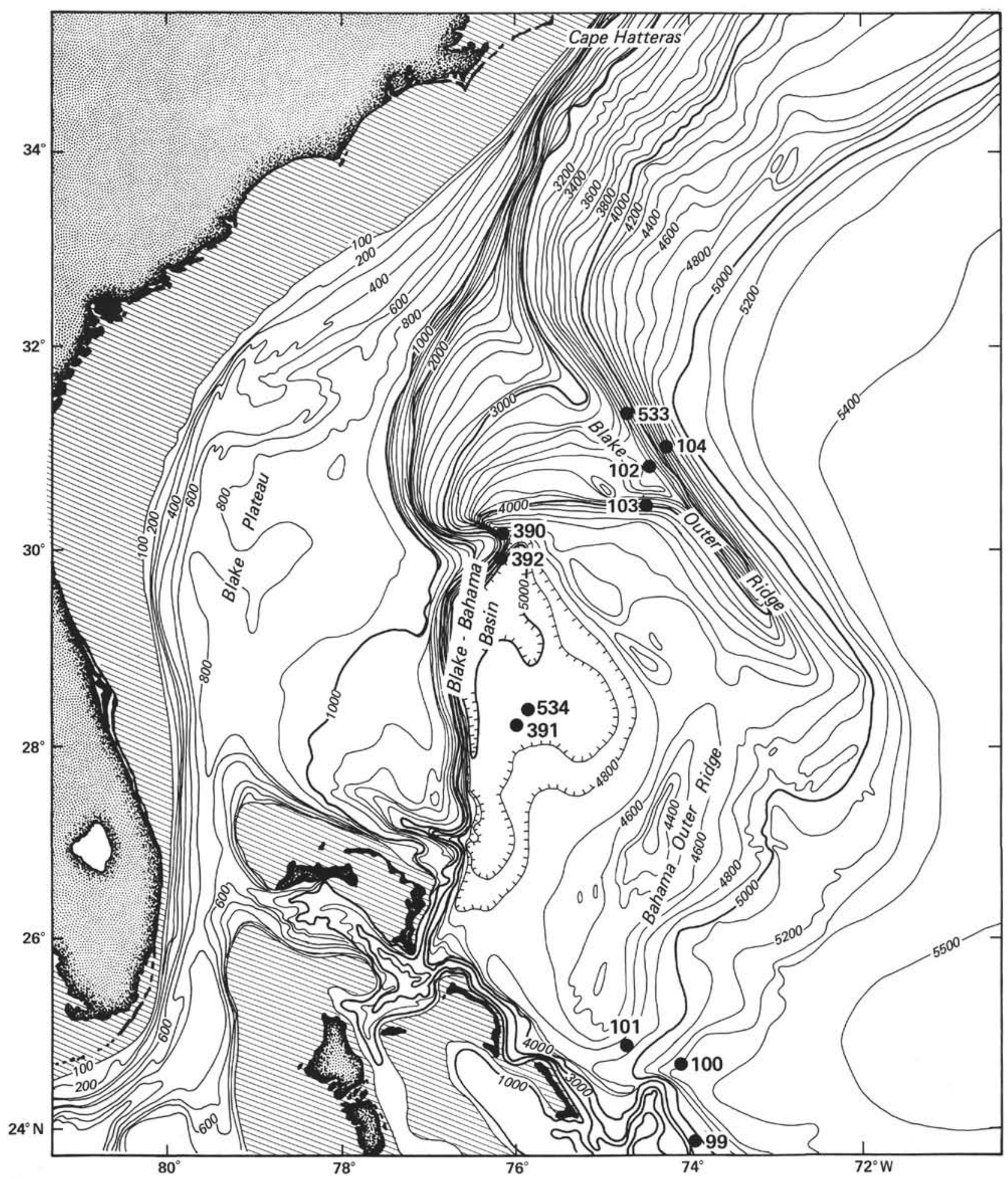

Figure 1. Location of DSDP Sites 534 and 391 relative to the general physiography.

estimated age, latest Oxfordian [Ogg et al., unpublished data]) and the Blake Spur Anomaly (110 km to the west, age unknown but estimated as late Bathonian-early $\mathrm{Cal}$ lovian [see Site 534 report]). This "quiet" zone has several low-amplitude magnetic anomalies; Site 534 is located on the eastern side of "M-28" of Bryan et al. (1980).
The Blake Spur Magnetic Anomaly coincides with a basement ridge, possibly formed by a jump of the spreading ridge in the Middle Jurassic (Vogt, 1973). Before the formation of the Blake Spur Anomaly, seafloor spreading presumably created the Inner Jurassic Magnetic Quiet Zone between the East Coast Magnetic Anomaly and the Blake Spur Anomaly, although in the 


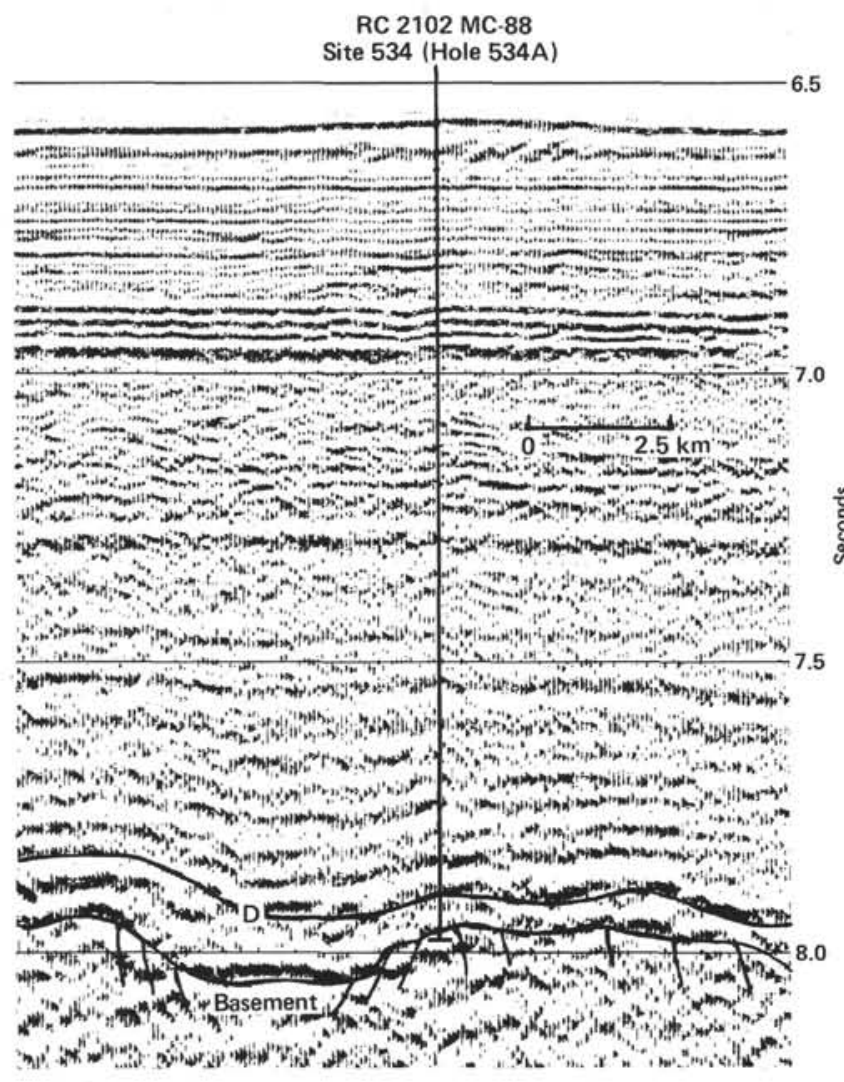

Figure 2. Seismic reflection profile of the Robert Conrad with inferred basement topography and the best estimate of the location of Site 534. region of the Blake Plateau Basin there is no evidence of oceanic crust west of the Blake Spur Anomaly. Instead, a deep, narrow $(20 \mathrm{~km})$ trough lies between the Blake Spur Basement Ridge and the Blake Escarpment (Fig. 3 ). The Blake Plateau is thought to have been a carbonate platform from the Middle Jurassic through early Late Cretaceous (Shipley et al., 1978).

The paleogeographic setting of Site 534 during the Jurassic is important for understanding the sedimentation history. The position at the time of deposition of the basal sediments was approximately equidistant from the edge of the Blake Plateau carbonate platform and the Guinea nose of Africa (Fig. 4). The paleolatitude was $9^{\circ} \mathrm{N} \pm 4^{\circ}$, as computed from the Callovian paleomagnetic poles of North America (Steiner, in press). The Bahama Banks were probably an active carbonate platform continuous with the Blake Plateau and Cuba, although Middle and Late Jurassic sediment facies have not yet been documented by boreholes (Schlager and Ginsburg, 1981). The adjacent Guinea nose and Bahama Platform probably restricted deep and mid-depth circulation between the early Atlantic and the Caribbean until a significant gap developed in the Late Jurassic (Sclater et al., 1977). A proposed paleogeographic reconstruction at the end of the Kimmeridgian is shown in Figure 5. At this time, the paleolatitude of the site was $24^{\circ} \mathrm{N} \pm 4^{\circ}$, as computed from the (?)Kimmeridgian-Tithonian paleomagnetic pole of North America (Steiner, in press); however, the paleomagnetic inclinations of the Site 534 sediments imply a $14.7^{\circ} \mathrm{N} \pm 2^{\circ}$ paleolatitude (Ogg, this volume). These Jurassic reconstructions,

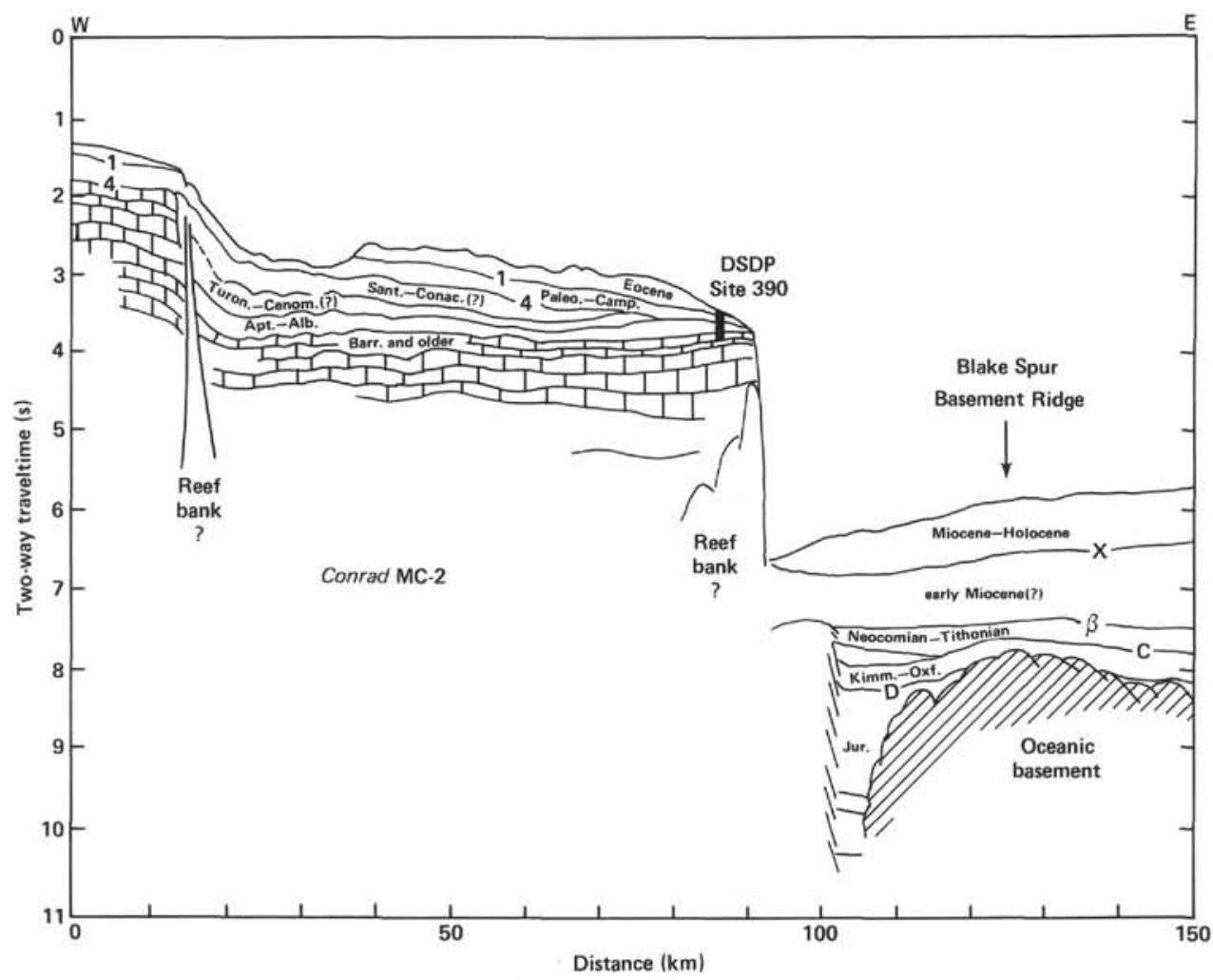

Figure 3. Interpretation of the seismic reflection profile across the Blake Escarpment and Blake Spur Basement Ridge (from Sheridan et al., 1979). 


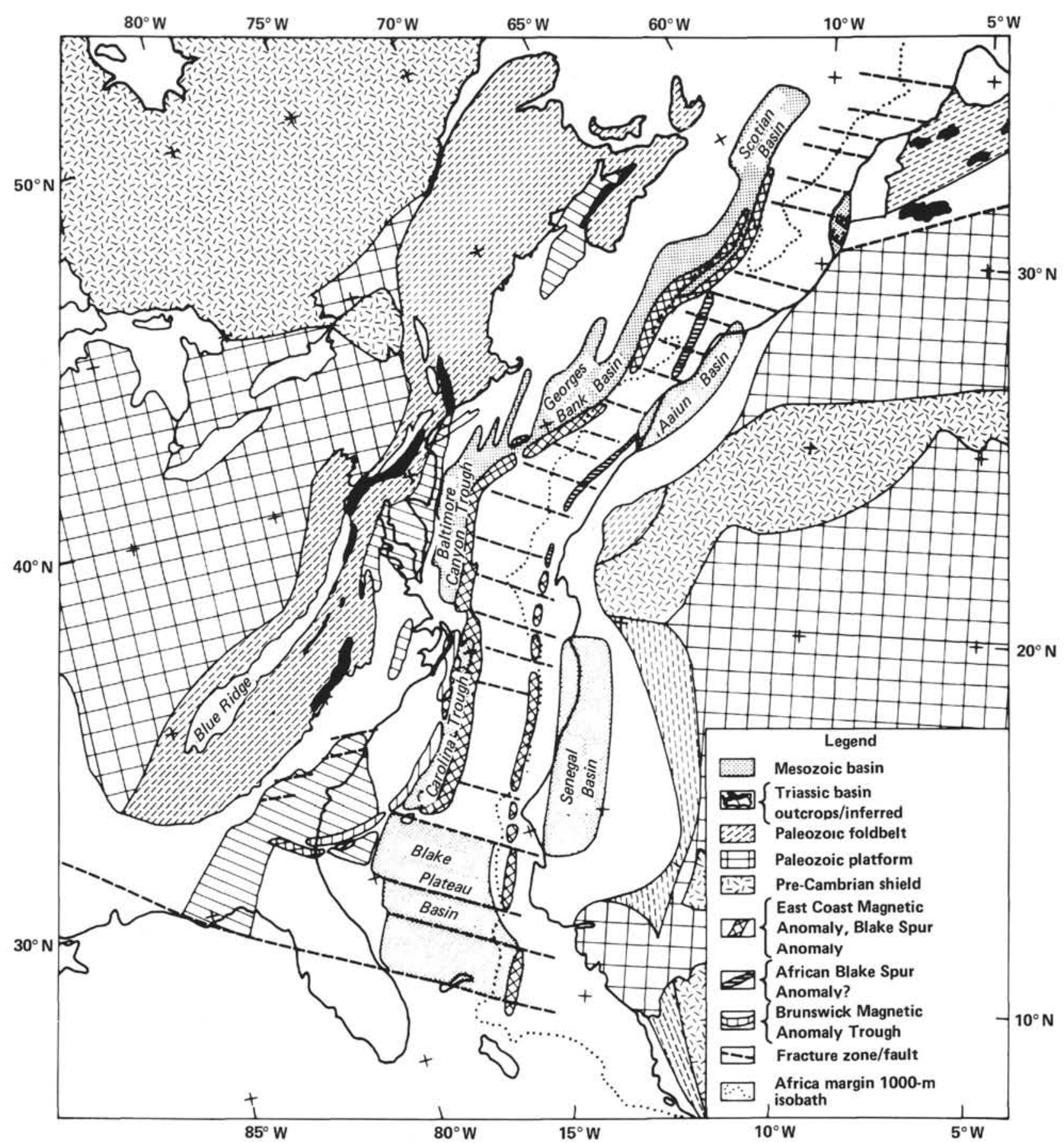

Figure 4. Reconstruction of the North Atlantic at the time of the Blake Spur Magnetic Anomaly (earliest Callovian). (Modified from Klitgord and Behrendt, 1979; and LePichon et al., 1977.)

which represent current views of the early spreading history of the Atlantic, will no doubt undergo major revisions as more data become available. Some possible modifications are discussed in Part Four of this chapter.

\section{Generalized Stratigraphy}

The Jurassic sediments of Site 534 are a succession of marl and claystone units with three intervals of lime-rich turbidites. The shipboard sedimentologists divided these into seven subunits on the basis of color and the presence or absence of lime-rich turbidites (see the detailed description in the Site 534 report). In this chapter, the main types of claystone and $\operatorname{marl}^{3}$ ("host" pelagic sediments) are discussed individually, separately from the intercalated carbonate turbidites.

\footnotetext{
${ }^{3}$ The classification system used here is: $<20 \% \mathrm{CaCO}_{3}=$ claystone; $20-50 \%=$ marl $50-80 \%=$ marly limestone; $>80 \%=$ limestone. (If $>10 \%$ is terrigeneous silt, then "silty" is used.)
} 


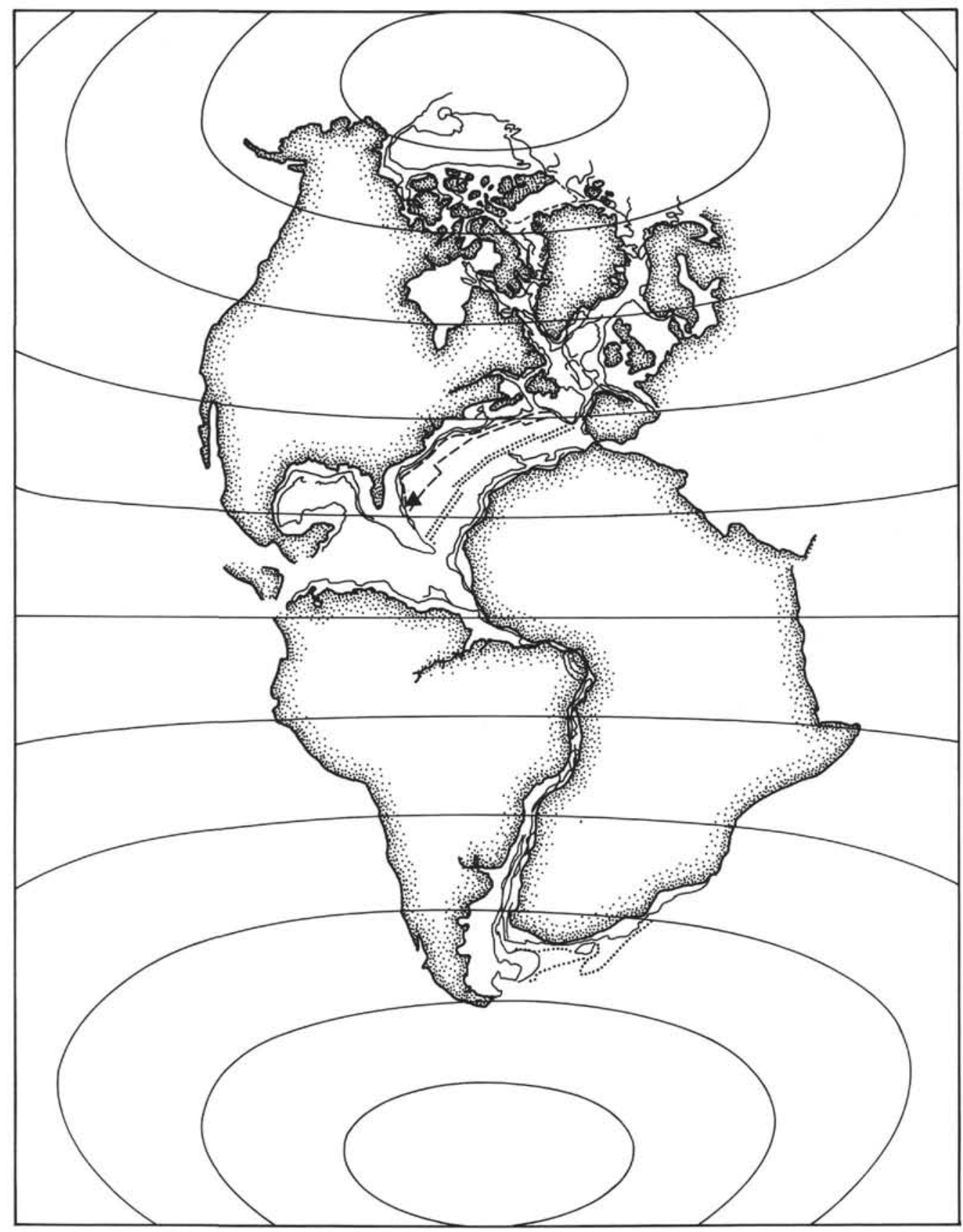

Figure 5. Reconstruction and paleobathymetry of the Atlantic at Marine Magnetic Anomaly M-22 (Tithonian/ Kimmeridgian boundary). (The present-day continental edge has been stipled: the 200 -m-paleodepth contour is a thin line; the $2000-\mathrm{m}$ contour a heavy continuous line; the $3000-\mathrm{m}$ contour a dotted line; and the $4000 \mathrm{~m}$ contour a dashed line. Site 534 is a black triangle. Modified from Sclater et al., 1977.)

The stratigraphy and ages of Hole 534A Jurassic units are summarized as follows:

\begin{tabular}{|c|c|c|c|}
\hline $\begin{array}{l}\text { Core-section, } \\
\mathrm{cm} \text { level }\end{array}$ & $\begin{array}{l}\text { Interval } \\
\text { (thickness) } \\
\text { (in m) }\end{array}$ & $\begin{array}{c}\text { Unit } \\
\text { (main lithology) }\end{array}$ & $\begin{array}{l}\text { Estimated } \\
\text { age }\end{array}$ \\
\hline $\begin{array}{l}92-1,40 \mathrm{~cm} \\
\text { through } 103\end{array}$ & $1342.0-1437.0(95 \mathrm{~m})$ & Red marl & $\begin{array}{l}\text { Tithonian- } \\
\text { ?Kimmeridgian }\end{array}$ \\
\hline $\begin{array}{l}104 \text { through } \\
110\end{array}$ & $1437.0-1495.5(53.5)$ & Greenish gray marl & $\begin{array}{l}\text { Kimmeridgian- } \\
\text { ?Oxfordian }\end{array}$ \\
\hline $\begin{array}{l}111 \text { through } \\
119\end{array}$ & $1495.5-1572.0(76.5)$ & Variegated claystone & Oxfordian \\
\hline $\begin{array}{l}120 \text { through } \\
127, \mathrm{CC}(10 \mathrm{~cm})\end{array}$ & $1572.0-1635.3(63.3)$ & $\begin{array}{l}\text { Greenish black silty } \\
\text { claystone, brown } \\
\text { silty inarl }\end{array}$ & $\begin{array}{l}\text { ?Oxfordian- } \\
\text { middle } \\
\text { Callovian }\end{array}$ \\
\hline
\end{tabular}

The Hole 534A turbidite intervals (marly limestone or limestone) are:

\begin{tabular}{|c|c|c|c|}
\hline $\begin{array}{l}\text { Core-section, } \\
\mathrm{cm} \text { level }\end{array}$ & $\begin{array}{c}\text { Interval } \\
\text { (thickness) } \\
\text { (in m) }\end{array}$ & Texture & Age \\
\hline $\begin{array}{l}100 \text { through } \\
114\end{array}$ & $1401.0-1531.5(130.5)$ & $\begin{array}{l}\text { Bioclast-poor } \\
\text { micrite }\end{array}$ & $\begin{array}{l}\text { ?Tithonian- } \\
\text { Oxfordian }\end{array}$ \\
\hline $\begin{array}{l}103 \text { through } \\
109\end{array}$ & $1428.0-1486.5(58.5)$ & $\begin{array}{l}\text { Skeletal-pelletal } \\
\text { microsparite }\end{array}$ & $\begin{array}{l}\text { Kimmeridgian- } \\
\text { ?Oxfordian }\end{array}$ \\
\hline $\begin{array}{l}115 \text { to } \\
125-4,20 \mathrm{~cm}\end{array}$ & $1531.5-1617.2(85.7)$ & Bioclastic pelmicrite & $\begin{array}{l}\text { Oxfordian- } \\
\text { ?late Callovian }\end{array}$ \\
\hline
\end{tabular}

These units and intervals are shown schematically in Figure 6. 


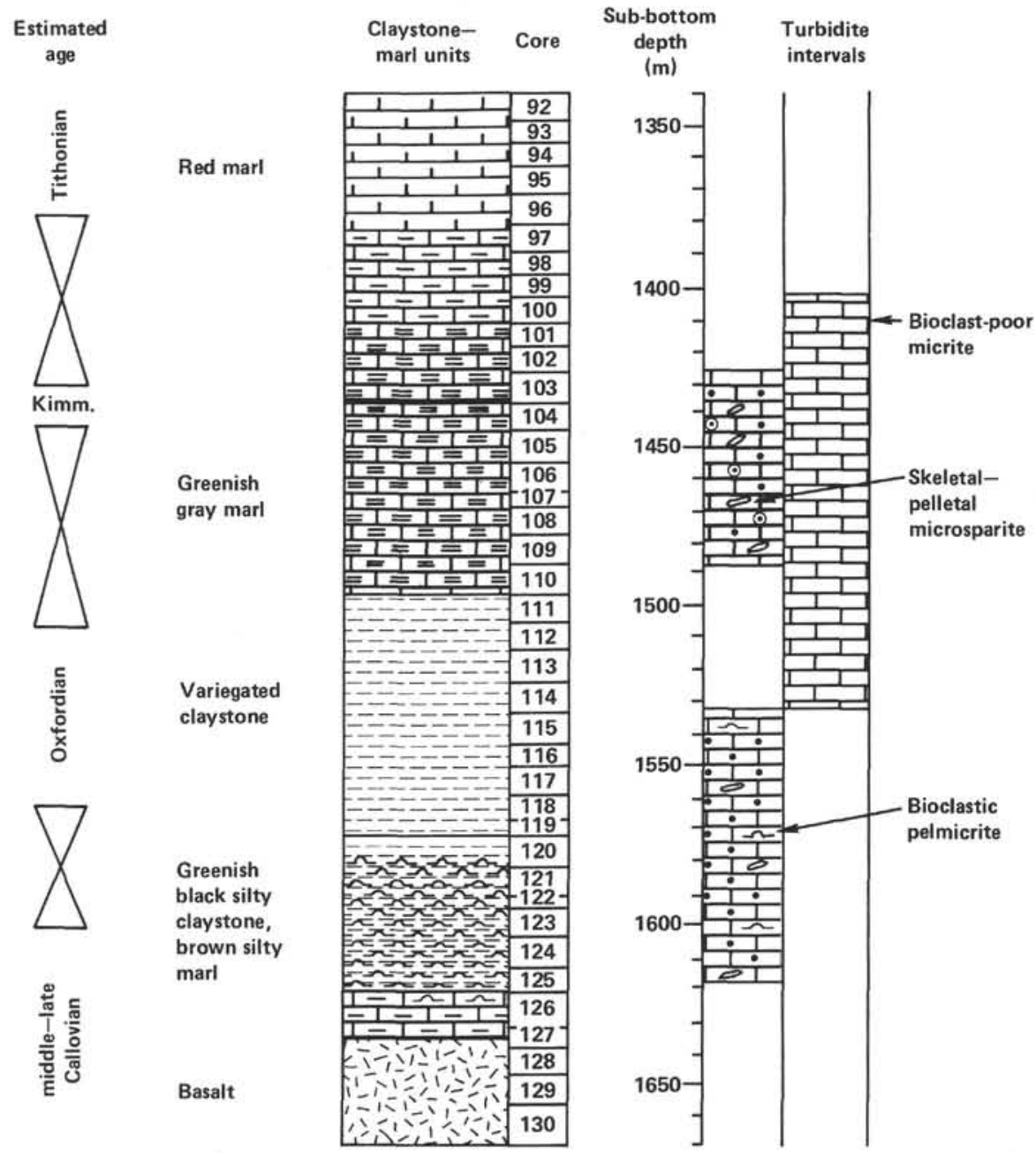

Figure 6. Jurassic stratigraphy of Site 534. (Claystone-marl units and turbidite intervals are shown separately.)

The contacts between the claystone and marl units are possible hiatuses or rapid changes in oceanographic conditions, although poor recovery may have concealed possible transitions. The two upper marl units are comparable in age and lithology to the Cat Gap Formation of Jansa et al. (1979) and are considered to be members of this Late Jurassic western North Atlantic Formation. The two lower claystone units are both older and of very different lithologies than the type section of the Cat Gap Formation at DSDP Site 105. The tops of the last two turbidite intervals listed have been correlated to seismic reflectors D and D' (Sheridan et al., this volume). The regional correlation and significance of this stratigraphy is discussed in Part Two of this paper.

\section{Basaltic Basement Complex}

The recovered basement complex (three cores only) is tholeiitic basalt composed of massive vesicular or aphyric pillows interstratified with basaltic breccia (Fig. 7). The fragments in the basaltic breccia beds are angular, moderately to intensely altered, and set in a matrix of quartz, calcite, and green clay (see Site 534 report).
Particularly notable is a drusy calcite cement of probable hydrothermal origin. There are several intercalations of laminated, reddish brown marly limestone and siliceous claystone as much as several centimeters thick. Alteration mineralogy includes smectite, green clays (?celadonite), palagonite, quartz, and calcite.

The basaltic complex was probably formed at the active oceanic spreading ridge. The lava breccia beds perhaps reflect extrusion on a sloping seafloor. Final volcanism was sufficiently episodic to allow accumulation of sediments essentially identical in primary composition to those immediately above the lavas. There is thus no hint of a significant hiatus between the end of volcanism and the overlying pelagic sedimentation.

The paleomagnetism of the basalt indicates that a normal polarity magnetic field was present throughout the episodes of emplacement (Steiner, this volume). Different flows have distinct clusters of inclinations, but most of these inclinations are steeper than predicted from the paleolatitude of the site during the Callovian. This may indicate a general block tilting toward the north. 


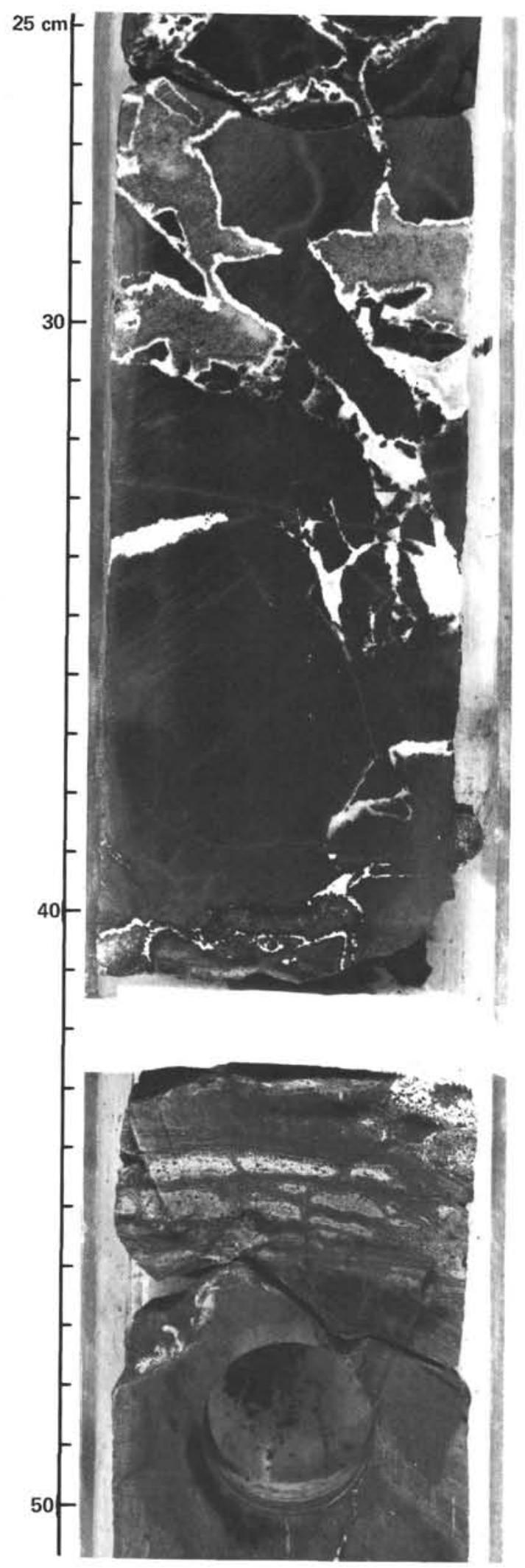

Figure 7. Features of basaltic basement complex (Sample 534A-129-2, $25-51 \mathrm{~cm}$ ). (Upper block is a brecciated basalt with angular fragments in a matrix of calcite, greenish clay, and quartz. Lower block is an altered chill zone of a basalt pillow. [The hole was a minicore for paleomagnetism].)

\section{Claystone-Marl Units}

\section{Greenish Black Silty Claystone, Brown Silty Marl (middle Callovian-?Oxfordian) Cores 120 to Sample 534A-127, CC $(10 \mathrm{~cm})$ (1572.0-1635.3 m sub-bottom)}

\section{Macroscopic Features}

The basal $10 \mathrm{~m}$ are dominated by dusky red silty marl (averaging $23 \% \mathrm{CaCO}_{3}, 15 \%$ terrigenous silt). The overlying greenish black silty claystone (averaging 15\% $\mathrm{CaCO}_{3}, 12 \%$ terrigenous silt) has numerous black carbonaceous clay layers. Thin radiolarian sand layers are abundant in the upper cores and less common in the brown marl. Within the underlying pillow basalts are rare pieces of brownish red marl. The main sedimentary structures are beds of claystone-marl intraclasts, slumping, and an apparent 10 to $15^{\circ}$ bedding dip, which may be postdeposition tectonic tilting. Burrows, mainly Chondrites, are rare even in the brown marl. Bioclastic pelmicrite turbidite beds are present in the middle of the unit and dominate the upper portion; these are discussed later.

The proportions of these different lithologies are tabulated for each recovered section in the Site 534 report (this volume). Assuming that the recovered lithologies indicate the actual proportions, then the net thickness of claystone and marl is 35 to $40 \mathrm{~m}$. The estimated time span is 4 to $6 \mathrm{~m}$.y., giving a sedimentation rate of 6 to 10 $\mathrm{m} / \mathrm{m} . \mathrm{y}$.

The beds have a general 10 to $15^{\circ}$ inclination, which greatly exceeds the measured $2.0^{\circ}$ deviation of the drill string at Core 120. Some layers have variable inclinations of lamination, which are perhaps cross-bedding.

The lower half of the unit has many beds of flattened, elongate intraclasts (Fig. 8). These intraclasts range in size from about 1 to $30 \mathrm{~mm}$ and are commonly packed in layers ranging from 4 to $45 \mathrm{~cm}$ in thickness. Grading occurs mainly in the thinner layers having smaller clasts. Interclasts are commonly greenish gray micritic marl containing a higher abundance of nannofossils and shell fragments than the host claystone. Other clasts include large biotite-chlorite flakes, fish bones, phosphate concretions, glauconite, possible volcaniclastics, mollusk and unidentified shell fragments, claystones with concentrated pyritized radiolarians, and claystone similar in texture to the host claystone. Plastic deformation is common.

Synsedimentary slumping is indicated by layers with folding, truncation, or deformation of bedding or lamination (Fig. 9). These features are most common in the lower half of the unit.

Chondrites burrows are visible at the tops of the calcareous turbidite beds, and possible burrow-mottling was observed in the basal brown marls.

\section{Microfacies and Mineralogy}

The brown silty marl of the basal cores is rich in siltsized $(10-20 \mu \mathrm{m})$ terrigenous clastics (averaging 10\% quartz, $5 \%$ mica), with about $5 \%$ opaques (mainly or- 


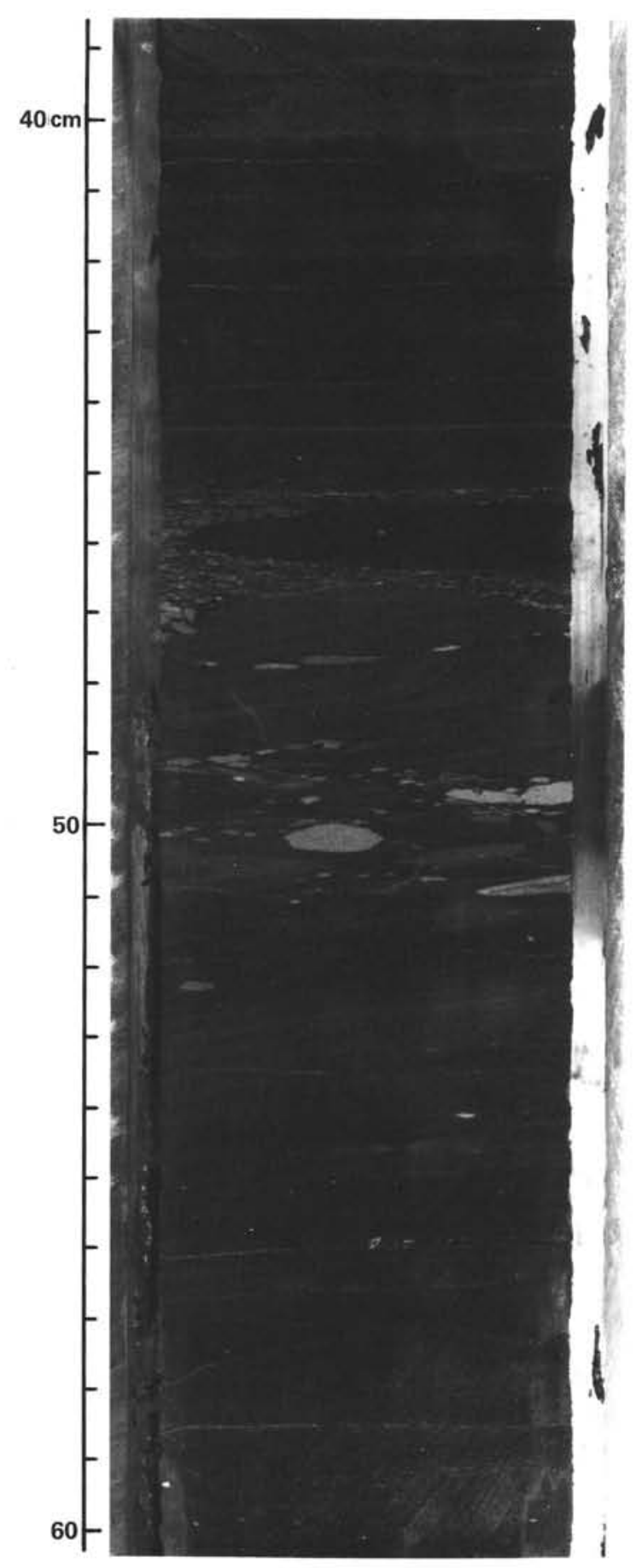

Figure 8. Claystone intraclast horizons in a basal unit of brown silty marl. (Intraclasts have a wide range of sizes and microfacies. A radiolarian-rich layer is at $41-42 \mathrm{~cm}$ (in Sample 534A-125-5, 39-60 $\mathrm{cm}$., middle to late Callovian).

ganic fragments) and rare clastic calcite and glauconite. The only microfossils are small bivalve shells, which are abundant (over 2\%) only in a few horizons near the base (Fig. 10). Generally, the marl is devoid of microfossils, but has abundant nannofossils (about 20\%) and phosphate fragments of fish bones $(3 \%)$. The range of composition is fairly narrow (see Table 1), excluding those

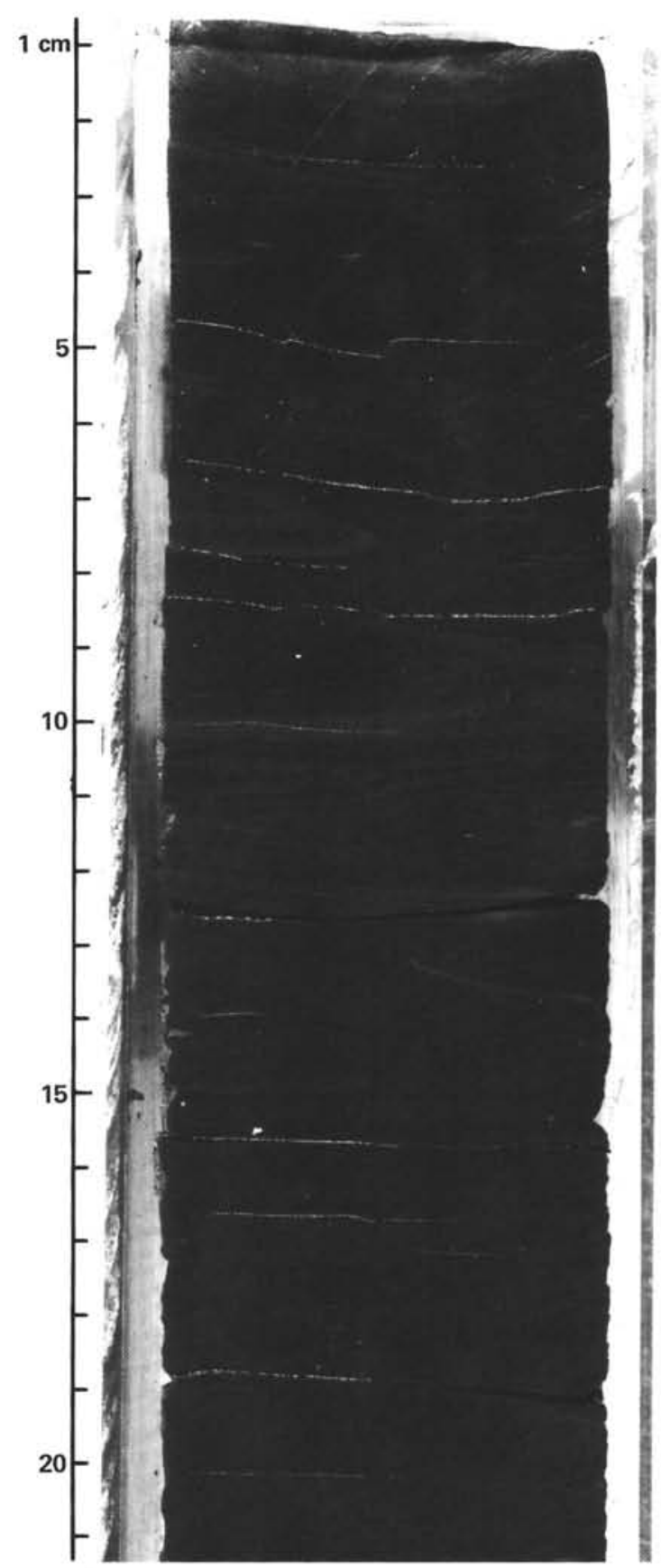

Figure 9. Synsedimentary slumping and folding in the basal unit of brown silty marl. (Sample 534A-126-2, 0-21 cm, middle to late Callovian).

anomalous layers with concentrations of small bivalve shells or large biotite-chlorite flakes.

The greenish gray to greenish black silty claystone displays an upward decline in the abundance of nannofossils (from 20-0\%) and carbonate (from 28 to $0 \%$ ) between Cores 126 and 122 . The abundance of terrigenous silt remains fairly constant (averaging 6\% quartz, 5\% mica) in this interval. The upper two cores (121 and 120) contain more nannofossils (about 5\%) and much less clastic silt (to $5 \%$ total). The claystone contains about 
Table 1. Microfacies of Callovian claystone marl, Hole 534A.

\begin{tabular}{|c|c|c|c|c|c|c|c|c|}
\hline \multirow{2}{*}{$\begin{array}{c}\text { Sample } \\
\text { (core-section, } \\
\mathrm{cm} \text { from top of section) }\end{array}$} & \multirow[b]{2}{*}{ Lithology } & \multirow[b]{2}{*}{ Bioclasts (\%) } & \multicolumn{5}{|c|}{ Silt-sized components $(\%)$} & \multirow[b]{2}{*}{ Comments } \\
\hline & & & Quartz & Mica & Opaques & Phosphate & Other & \\
\hline $120-1,44$ & Purplish claystone & None & 3 & 2 & 2 & 2 & & \\
\hline $121-1,8$ & Green claystone & $\begin{array}{l}\text { Possible pyritized radio- } \\
\text { larian fragments }\end{array}$ & 2 & 8 & 3 & 1 & & \\
\hline $122-2,41$ & Green claystone & None & 2 & 4 & 3 & 1 & & \\
\hline $122-2,40$ & Radiolarian sand & $\begin{array}{l}\text { Silica-filled, replaced } \\
\text { radiolarians }(35 \%)\end{array}$ & 0 & 1 & 0 & 1 & Pyrite & $\begin{array}{l}\text { Some micrite-filled } \\
\text { radiolarians }\end{array}$ \\
\hline $122-2,128$ & Radiolarian sand & $\begin{array}{l}\text { Silica-filled, replaced } \\
\text { radiolarians }(40)\end{array}$ & 0 & 1 & 0 & 1 & Pyrite & $\begin{array}{l}\text { Abundant, clay- } \\
\text { sized organics }\end{array}$ \\
\hline $123-1,6$ & $\begin{array}{l}\text { Reddish black clay- } \\
\text { stone }\end{array}$ & None & 5 & 0 & 0 & 2 & & Rare micrite lens \\
\hline $123-2,98$ & Dark gray claystone & $\begin{array}{l}\text { Pyritized, calcite-filled } \\
\text { radiolarians }(2-3),\end{array}$ & 8 & 15 & 4 & 3 & & $\begin{array}{l}\text { Possible fragments } \\
\text { of volcaniclas- } \\
\text { tics }\end{array}$ \\
\hline $124-1,74$ & $\begin{array}{l}\text { Laminated brown } \\
\text { claystone }\end{array}$ & $\begin{array}{l}\text { small shell fragments(?) } \\
\text { (rare) }\end{array}$ & 0 & 2 & 2 & 1 & Pyrite (3) & \\
\hline $\begin{array}{l}124-1,79 \\
.\end{array}$ & $\begin{array}{l}\text { Laminated black } \\
\text { claystone }\end{array}$ & $\begin{array}{l}\text { Pyritized radiolarian } \\
\text { fragments (3), cal- } \\
\text { cite fillings of radio- } \\
\text { larians (1) }\end{array}$ & 10 & 10 & 5 & 2 & & $\begin{array}{l}\text { Micritic lenses } \\
\text { (pellets?), } \\
\text { possible } \\
\text { volcaniclastic } \\
\text { fragments }\end{array}$ \\
\hline $125-4,67$ & $\begin{array}{l}\text { Claystone intraclast } \\
\text { zone }\end{array}$ & $\begin{array}{l}\text { Pelecypod fragment } \\
(2 \mathrm{~mm}) \text {, pocket of } \\
\text { pyritized, calcite- } \\
\text { filled radiolarians }\end{array}$ & - & - & - & - & & Discussed in text \\
\hline $125-4,78$ & $\begin{array}{l}\text { Greenish black } \\
\text { claystone }\end{array}$ & None & 4 & 2 & 5 & 1 & 'Glauconite & $\begin{array}{l}\text { Phosphate concre- } \\
\text { tions; Chon- } \\
\text { drites bur- } \\
\text { rows(?) }\end{array}$ \\
\hline $125-5,42$ & $\begin{array}{l}\text { Grayish black clay- } \\
\text { stone }\end{array}$ & $\begin{array}{l}\text { Pyritized, calcite-filled } \\
\text { radiolarians (10) }\end{array}$ & 0 & 0 & 10 & 3 & & $\begin{array}{l}\text { Possible micrite } \\
\text { pellets }\end{array}$ \\
\hline $125-5,46$ & $\begin{array}{l}\text { Radiolarian clay- } \\
\text { stone }\end{array}$ & $\begin{array}{l}\text { Pyritized, silica-filled } \\
\text { radiolarians (15) }\end{array}$ & 8 & 4 & 4 & 0 & & \\
\hline $125-5,45$ & $\begin{array}{l}\text { Greenish brown } \\
\text { claystone }\end{array}$ & Radiolarians (15) & 5 & 3 & 5 & 1 & Glauconite & $\begin{array}{l}\text { Sharp contacts to } \\
\text { adjacent lithol- } \\
\text { ogies }\end{array}$ \\
\hline $125-5,44$ & $\begin{array}{l}\text { Claystone inter- } \\
\text { clasts zone }\end{array}$ & None & - & - & - & - & & Discussed in text \\
\hline $125-5,57$ & $\begin{array}{l}\text { Claystone inter- } \\
\text { clasts zone }\end{array}$ & $\begin{array}{l}\text { Small shells in micritic } \\
\text { clasts, rare pyritized } \\
\text { radiolarians in } \\
\text { matrix }\end{array}$ & - & - & - & - & & Discussed in text \\
\hline $125-6,32$ & $\begin{array}{l}\text { Laminated greenish } \\
\text { gray claystone }\end{array}$ & $\begin{array}{l}\text { Pyritized radiolarians } \\
\text { (2), small shell frag- } \\
\text { ments (2) }\end{array}$ & 5 & 4 & 5 & 2 & & $\begin{array}{l}\text { Pyrite is common- } \\
\text { ly oxidized; } \\
\text { rare phosphate } \\
\text { concretions }\end{array}$ \\
\hline $126-1,25$ & $\begin{array}{l}\text { Claystone interclast } \\
\text { zone }\end{array}$ & $\begin{array}{l}\text { Pyritized radiolarians } \\
\text { in pockets }\end{array}$ & - & - & - & - & & $\begin{array}{l}\text { Variety of intra- } \\
\text { clasts discussed } \\
\text { in text }\end{array}$ \\
\hline $126-1,25$ & $\begin{array}{l}\text { Greenish gray clay- } \\
\text { stone }\end{array}$ & $\begin{array}{l}\text { Pyritized, commonly } \\
\text { calcite-filled radio- } \\
\text { larian fragments (6) }\end{array}$ & 10 & 5 & 8 & 2 & & $\begin{array}{l}\text { Rare micrite } \\
\text { pellets }\end{array}$ \\
\hline $126-1,34$ & $\begin{array}{l}\text { Green black clay- } \\
\text { stone with ra- } \\
\text { diolarian-rich } \\
\text { laminae }\end{array}$ & $\begin{array}{l}\text { Pyrite-replaced, calcite- } \\
\text { filled radiolarians } \\
(1-10)\end{array}$ & 5 & 2 & 3 & 2 & & \\
\hline $126-2,98$ & Black claystone & $\begin{array}{l}\text { Calcite-filled, pyrite- } \\
\text { replaced radiolarians } \\
\text { (2) }\end{array}$ & 5 & 0 & 2 & 1 & $\begin{array}{l}\text { Clastic } \\
\quad \text { calcite (1) }\end{array}$ & \\
\hline $126-2,98$ & Radiolarian sand & $\begin{array}{l}\text { Silica-filled radiolarians } \\
\text { (30) }\end{array}$ & 0 & 5 & 7 & 2 & $\begin{array}{l}\text { Pyrite } \\
\text { skeletal } \\
\text { fragments } \\
\text { (3) }\end{array}$ & $\begin{array}{l}\text { Radiolarians are } \\
\text { often pyrite- } \\
\text { replaced; large } \\
\text { biotite-chlorite } \\
\text { flakes }(5 \%)\end{array}$ \\
\hline $126-3,97$ & $\begin{array}{l}\text { Brown marl with } \\
\text { black grains }\end{array}$ & Shell fragments (rare) & 3 & 9 & 8 & 5 & $\begin{array}{l}\text { Glauconite } \\
\text { clastic } \\
\text { calcite }\end{array}$ & $\begin{array}{l}\text { Large chlorite- } \\
\text { biotite flakes }\end{array}$ \\
\hline $126-3,100$ & $\begin{array}{l}\text { Greenish gray clay- } \\
\text { stone }\end{array}$ & None & 5 & 13 & 2 & 0 & & $\begin{array}{l}\text { Large biotite } \\
\text { flakes }\end{array}$ \\
\hline $126, \mathrm{CC}(10)$ & Brown marl & None & 5 & 4 & 3 & 2 & $\begin{array}{l}\text { Clastic } \\
\text { calcite }\end{array}$ & \\
\hline $127-1,10$ & Brown marl & None & 20 & 3 & 7 & 2 & $\begin{array}{l}\text { Feldspar, } \\
\text { pyrite, } \\
\text { clastic } \\
\text { calcite, } \\
\text { siderite }\end{array}$ & \\
\hline $127-1,107$ & $\begin{array}{l}\text { Brown marl with } \\
\text { black grains }\end{array}$ & Small shells (3) & 15 & 5 & 5 & 3 & $\begin{array}{l}\text { Glauconite } \\
\text { (2) }\end{array}$ & $\begin{array}{l}\text { Large biotite-chlo- } \\
\text { rite flakes }\end{array}$ \\
\hline $127-2,31$ & Greenish gray marl & None & 7 & 3 & 2 & & $\begin{array}{r}\text { Pyrite-rich } \\
\text { horizon }\end{array}$ & \\
\hline $127-3,11$ & Brown marl & None & 7 & 5 & 7 & 5 & & $\begin{array}{l}\text { Elongate, fine } \\
\text { sand-sized } \\
\text { phosphate }\end{array}$ \\
\hline $127-3,76$ & Brown marl & $\begin{array}{l}\text { Small shell fragments } \\
\text { (rare) }\end{array}$ & 1 & 0 & 5 & 2 & & \\
\hline $127-3,76$ & $\begin{array}{l}\text { Green bioclast } \\
\text { horizon }\end{array}$ & Small shells (up to 25 ) & 10 & 5 & 5 & 5 & Glauconite & $\begin{array}{l}\text { Chlorite replacing } \\
\text { biotite }\end{array}$ \\
\hline $127-4,9$ & Brown marl & $\begin{array}{l}\text { Small shell fragments } \\
\text { (rare) }\end{array}$ & 15 & 8 & 7 & 5 & & \\
\hline $128-3,108^{a}$ & $\begin{array}{l}\text { Brown marl be- } \\
\text { tween pillow } \\
\text { basalts }\end{array}$ & $\begin{array}{l}\text { Small shell fragments } \\
\text { (5), silicified fora- } \\
\text { minifers (rare) }\end{array}$ & - & - & - & - & - & $\begin{array}{c}\text { Bioclasts in } \\
\text { laminae }\end{array}$ \\
\hline
\end{tabular}

actual thin section not available; data taken from the shipboard scientists' description ( $R$. Tyson, personal communication, 1980); - indicate no data. 


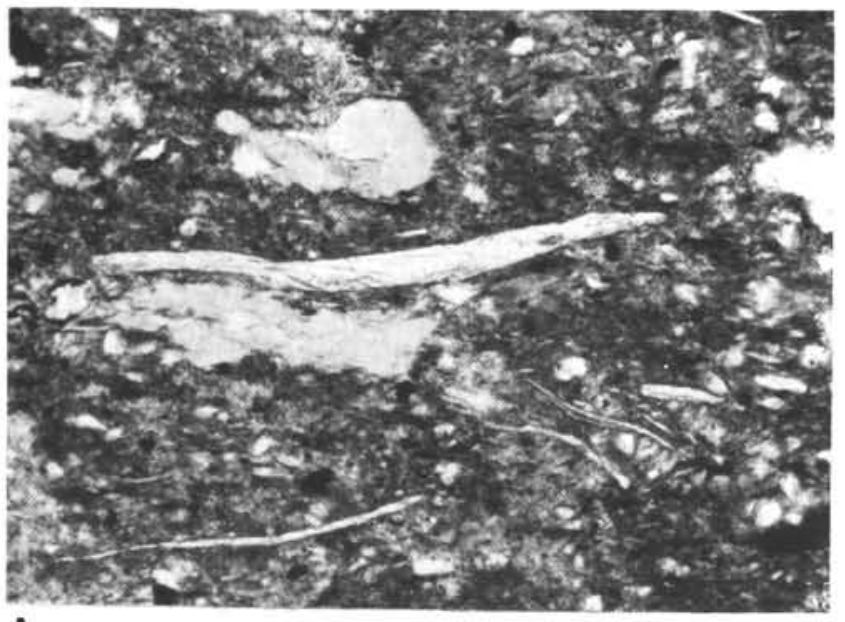

A

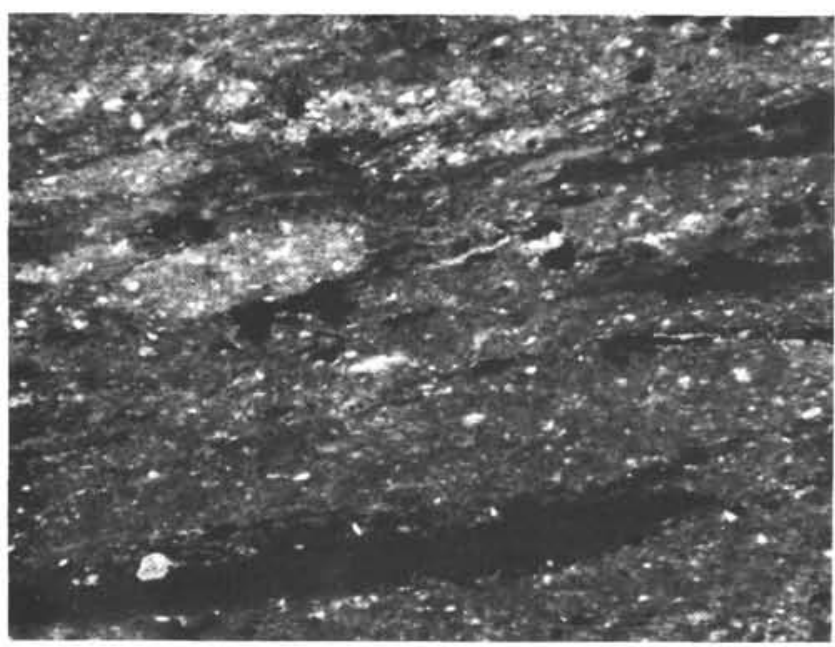

B

Figure 10. A. Bioclastic nannofossil marl with abundant chlorite-biotite. (The central large shell fragment is $0.4 \mathrm{~mm}$ long; the adjacent large light-colored grains are chlorite-biotite. Thin "filaments," quartz grains, phosphatic debris, and glauconite are abundant to common. This thin section [Sample 534A-127-1, $107 \mathrm{~cm}$ ] of the basal brown silty marl is relatively rich in silt-sized bioclasts and clastics; its age is middle to late Callovian.) B. Claystone intraclast horizon (Sample 534A-126-1, 25 cm). (Intraclasts are packed together and are plastically deformed so that the most abundant type appears to form a "matrix." Textures range from fine bioclastic silty marl to dark amorphous clay [such as the elongate 1.5 -mm-long clast at the bottom]. The small bright grain at bottom left is a phosphate concretion. Quartz-rich silt is abundant. The age is middle to late Callovian.)

$5 \%$ organic fragments, plus an additional 1 to $4 \%$ of finely disseminated clay-sized amorphous organic material, which produces the dark color. The only microfossils present are radiolarians, all replaced by pyrite, and generally filled by calcite spar where skeletons are fairly intact (Fig. 11). Odd-shaped pyritized radiolarian fragments are numerous in the claystone; the radiolarian abundance ranges from 1 to $10 \%$. Other clasts are phosphatic fish-bone fragments, rare glauconite, and very rare phosphate concretions and shell fragments. Most

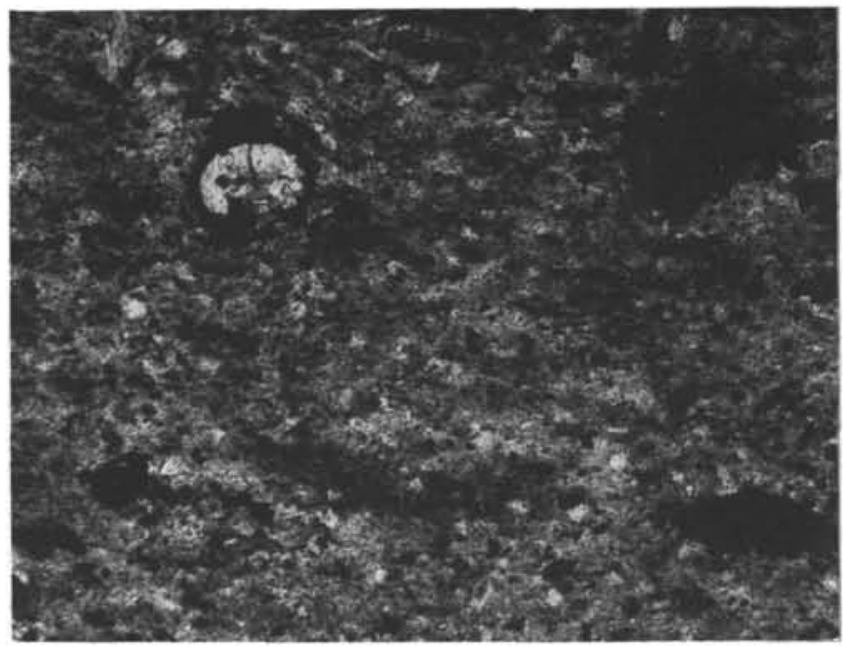

Figure 11. Photomicrograph of dark greenish gray silty claystone unit. (Scattered radiolarians have pyritized tests and are commonly filled with sparry calcite. Radiolarian at upper left is $80 \mu \mathrm{m}$ in diameter. Fine organic material and quartz-rich silt are abundant. Sample 534A-126-2, $96 \mathrm{~cm}$, middle to late Callovian.)

of the claystones are laminated, or have a pseudolamination produced by the parallel alignment of all micas or other platy grains of the aligned clay minerals; thin sections cut normal to bedding display preferred optical orientation of minerals under polarizers.

The petrology of the black claystone intervals seems to be similar to the greenish gray claystone, but with fewer silt-sized clasts and a higher concentration of claysized organic particles. Organic carbon values can attain $2 \%$.

The mineralogy of the claystones is dominated by smectite, with large amounts of illite (up to $45 \%$ ), along with detrital silt grains of quartz, feldspar, and minor amphiboles (see Chamley et al., this volume). The smectite is less abundant than in the overlying variegated claystone unit, and becomes less well crystallized approaching the basaltic basement. Near the basalts, kaolinite (up to $10 \%$ ) and traces of palygorskite and "corrensite," a well crystallized chlorite-illite mineral, were identified. The diagenetic formation of corrensite is poorly understood, but it is probably a product of sedimentbasalt interaction. This interaction may have been facilitated by elevated temperatures produced by the high heat flow on the flank of the spreading ridge beneath the thermal blanket of clay sediments. This interaction may have also produced an oxidizing zone near the basalts, hence explaining the brownish red color of the basal sediments.

Horizons of radiolarian sand are abundant in the unit, especially within the greenish black claystone (Fig. 12). These horizons are about 0.5 to $1.0 \mathrm{~cm}$ thick, with sharp contacts and rare grading. Radiolarians comprise 30 to $40 \%$ of these layers and are generally replaced and filled with silica (spherulitic chalcedony) (Fig. 13). The claystone matrix between these 50 to $150-\mu \mathrm{m}$ (fine sand) radiolarian tests resembles the host claystones. Pyritized tests are not common, but fragments are seen. 


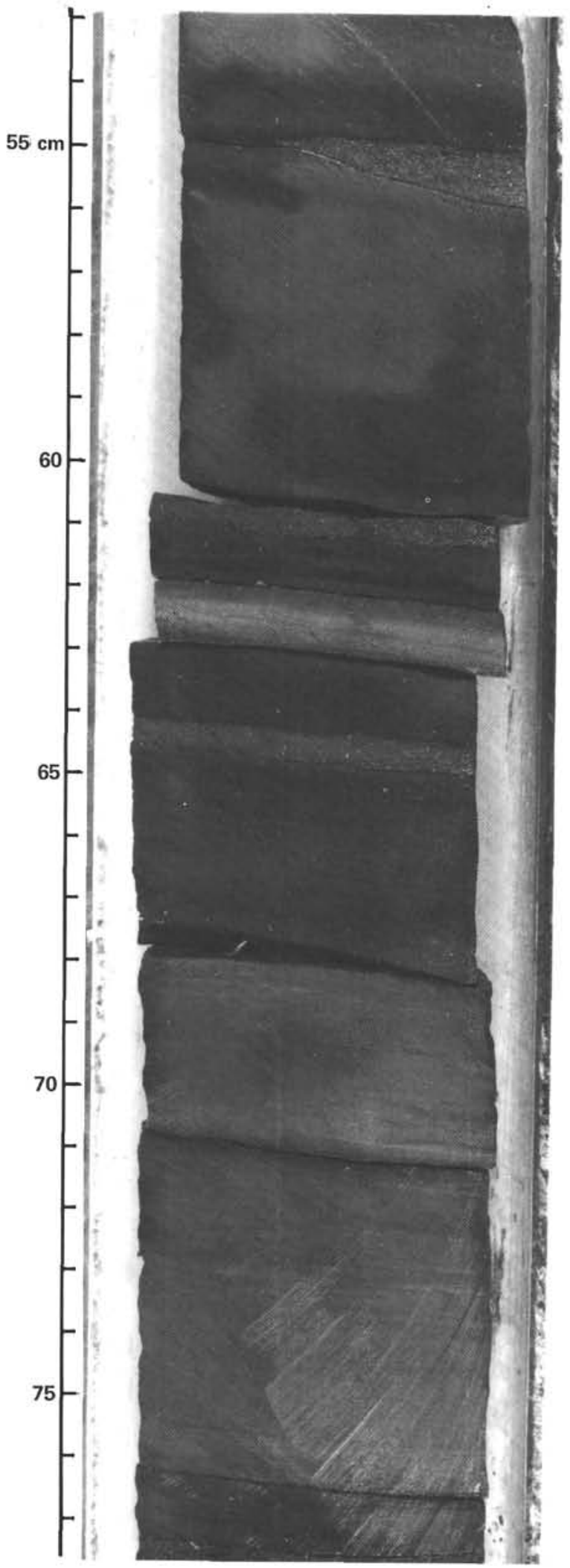

Figure 12. Greenish black claystone with thin layers of radiolarian sand (at 55,61,63,65, 68, and $78 \mathrm{~cm}$ levels). (The lenticular shape of some of these layers appears to be primary, which suggests current transport or winnowing. The gray bed between 68 and $76 \mathrm{~cm}$ is a marly limestone of turbidite origin. Sample 534A-120-1, 53-78 cm, middle to late Callovian.)

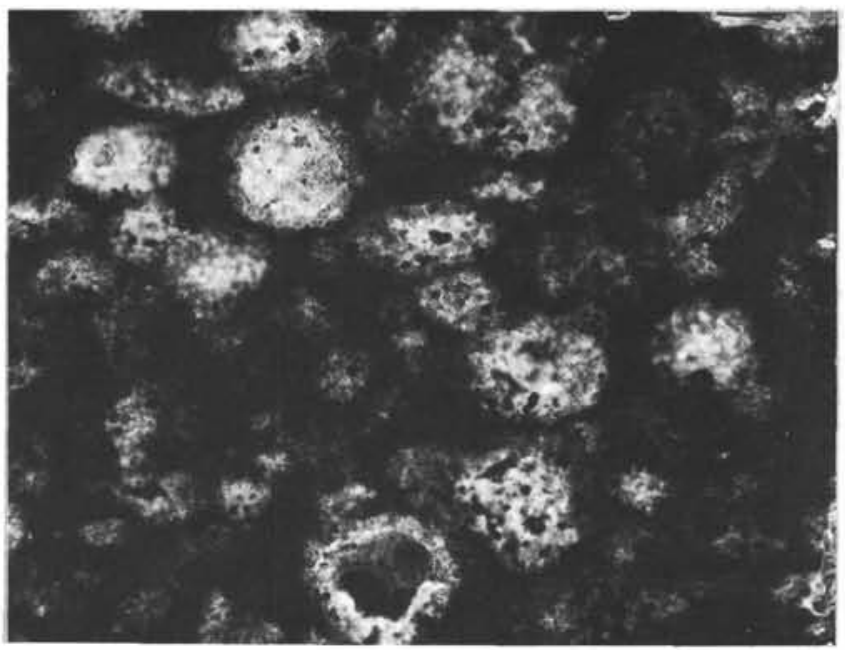

Figure 13. Photomicrograph of a radiolarian sand layer (thin section, Sample 534A-122-1, $113 \mathrm{~cm}$ ). (Radiolarians are replaced or filled by spherulitic chalcedony silica. The large radiolarians are about $80 \mu \mathrm{m}$ in diameter. The matrix is organic-rich silty claystone, the age, middle to late Callovian.)

\section{Chemistry}

Carbonate percentages generally decline from the brown marl (20-30\%) through the greenish gray black claystones of the middle portion (15-25\%), then decrease sharply in the upper cores. Both analyses of Cores 120 to 122 gave $0 \%$, but smear slides indicated as much as $5 \%$ nannofossils. It is possible that the low values in the upper cores are made even lower by dissolution, migration, then reprecipitation in adjacent marly limestone turbidite beds during diagenesis.

Organic carbon values exceed $1.0 \%$ in the greenish black claystones of cores 123 to 126 , with a value of $2.8 \%$ measured in one "black" layer. This value is as high as any of the Cretaceous "black shale" values at Site 534, and the average of the organic carbon content of this unit is only slightly less than the average of the Cretaceous "black shale" Hatteras formation. Hence this unit could be termed "Callovian black shales."

The major element chemistry of 18 representative samples in this interval was analyzed (method described by Norrish and Hutton, 1969). Minor element analyses were performed on 12 of these samples. The major and minor element data (on a $\mathrm{CO}_{3}$-free basis) are presented in Table 2.

The major elements $\mathrm{Fe}, \mathrm{Mn}$, and $\mathrm{Al}$ are particularly important in assessing the relative contribution to the sediment of terrigenous material versus metal-rich precipitates of hydrothermal derivation. The ratio of $(\mathrm{Fe}+\mathrm{Mn}) / \mathrm{Al}$ has been used as an indication of the importance of hydrothermal exhalations to sediment composition near the East Pacific Rise (Bostrom et al., 1969; Boström, 1973, 1977), and the accumulation rates of $\mathrm{Fe}$ and $\mathrm{Mn}$ reflects variations in ridge activity with time (Heath and Dymond, 1977; Leinen and Stakes, 1979).

The ratio $(\mathrm{Fe}+\mathrm{Mn}) / \mathrm{Al}$ for typical Atlantic hemipelagic sediment is less than 0.65 (Boström et al., 1969); a similar mean ratio of $0.6 \pm 0.1$ is found in the Creta- 
Table 2. Chemistry of Hole 534A basal sediments (on a $\mathrm{CO}_{3}$-free basis) by sample (core-section, cm interval) and lithology.

\begin{tabular}{|c|c|c|c|c|c|c|c|c|c|}
\hline & $122-1,56-60$ & $122-1,87-90$ & $123-2,21-23$ & $123-3,18-20$ & $124-1,34-36$ & $124-1,44-47$ & $125-4,77-80$ & $125-5,46-48$ & $126-1,62-63$ \\
\hline & $\begin{array}{l}\text { Olive gray marly } \\
\text { limestone }\end{array}$ & $\begin{array}{c}\text { Greenish black } \\
\text { silty clay }\end{array}$ & $\begin{array}{l}\text { Greenish silty } \\
\text { radiolarian clay }\end{array}$ & $\begin{array}{l}\text { Gray } \\
\text { marl }\end{array}$ & $\begin{array}{l}\text { Gray marly } \\
\text { limestone }\end{array}$ & $\begin{array}{l}\text { Gray marl } \\
\text { limestone }\end{array}$ & $\begin{array}{l}\text { Green } \\
\text { claystone }\end{array}$ & $\begin{array}{l}\text { Green } \\
\text { claystone }\end{array}$ & $\begin{array}{l}\text { Green mottled } \\
\text { claystone }\end{array}$ \\
\hline \multicolumn{10}{|c|}{ Major elements (\%) } \\
\hline $\mathrm{SiO}_{2}$ & 28.85 & 70.76 & 42.34 & 44.17 & 26.84 & 25.46 & 61.03 & 61.63 & 65.20 \\
\hline $\mathrm{Al}_{2} \mathrm{O}_{3}$ & 3.30 & 9.64 & 8.46 & 7.30 & 4.94 & 4.25 & 9.98 & 10.22 & 13.05 \\
\hline $\mathrm{Fe}_{2} \mathrm{O}_{3}$ & 2.27 & 12.46 & 6.81 & 5.36 & 3.59 & 3.31 & 16.95 & 7.60 & 8.07 \\
\hline $\mathrm{MgO}$ & 1.50 & 3.51 & 2.40 & 2.34 & 1.97 & 1.80 & 2.40 & 2.58 & 2.84 \\
\hline $\mathrm{CaO}$ & 55.87 & 0.38 & 33.66 & 35.74 & 54.45 & 56.03 & 5.39 & 13.35 & 5.72 \\
\hline $\mathrm{Na}_{2} \mathrm{O}$ & 0.05 & 0.53 & 0.41 & 0.28 & 0.08 & 0.04 & 0.56 & 0.62 & 1.03 \\
\hline $\mathrm{K}_{2} \mathrm{O}$ & 0.44 & 1.45 & 1.77 & 1.36 & 0.85 & 0.74 & 2.54 & 2.74 & 3.21 \\
\hline $\mathrm{TiO}_{2}$ & 0.18 & 0.39 & 0.48 & 0.42 & 0.29 & 0.20 & 0.60 & 0.56 & 0.74 \\
\hline $\mathrm{MnO}$ & 1.08 & 0.03 & 0.45 & 0.48 & 0.99 & 1.05 & 0.12 & 0.22 & 0.13 \\
\hline $\mathrm{P}_{2} \mathrm{O}_{5}$ & 0.06 & 0.04 & 0.08 & 0.15 & 0.07 & 0.04 & 0.13 & 0.17 & 0.06 \\
\hline Total & 93.61 & 99.18 & 96.86 & 97.61 & 94.07 & 92.93 & 99.69 & 99.70 & 100.64 \\
\hline \multicolumn{10}{|c|}{ Minor elements (ppm) } \\
\hline $\mathrm{Ni}$ & 40 & 169 & 113 & 76 & 42 & 30 & 132 & 53 & \\
\hline $\mathrm{Cr}$ & 25 & 55 & 67 & 56 & 35 & 28 & 108 & 96 & \\
\hline $\mathrm{V}$ & 37 & 85 & 117 & 94 & 68 & 52 & 179 & 198 & \\
\hline $\mathrm{Sc}$ & 0 & 14 & 0 & 0 & 0 & $*$ & 16 & 18 & \\
\hline $\mathrm{Cu}$ & 34 & 115 & 136 & 55 & 38 & 16 & 120 & 187 & \\
\hline $\mathrm{Zn}$ & 35 & 83 & 138 & 79 & 50 & 46 & 393 & 124 & \\
\hline $\mathrm{Sr}$ & 589 & 127 & 454 & 493 & 613 & 620 & 235 & 258 & \\
\hline $\mathbf{R p}$ & 24 & 67 & 74 & 59 & 39 & 35 & 104 & 115 & \\
\hline $\mathrm{Zr}$ & 33 & 73 & 91 & 75 & 55 & 37 & 116 & 109 & \\
\hline $\mathrm{Nb}$ & 0 & 7 & 8 & 6 & 3 & 1 & 11 & 9 & \\
\hline $\mathrm{Ba}$ & 60 & 463 & 153 & 77 & 3 & 13 & 179 & 151 & \\
\hline $\mathrm{Pr}$ & 16 & 21 & 27 & 20 & 15 & 14 & 50 & 17 & \\
\hline Th & 2 & 7 & 7 & 7 & 3 & 4 & 9 & 7 & \\
\hline $\mathrm{La}$ & 222 & 11 & 123 & 141 & 220 & 228 & 26 & 66 & \\
\hline $\mathrm{Ce}$ & 35 & 18 & 49 & 62 & 38 & 33 & 57 & 75 & \\
\hline $\mathrm{Nd}$ & 21 & 8 & 24 & 33 & 21 & 18 & 31 & 42 & \\
\hline $\mathrm{Y}$ & 20 & 13 & 25 & 31 & 25 & 21 & 31 & 42 & \\
\hline
\end{tabular}

Note: Blank space indicates no data were available.

ceous Blake-Bahama Formation (Robertson and Bleifnick, this volume; Murdmaa et al., 1978). The detrital component of sediment in the Pacific has a slightly higher ratio of 0.76 (Heath and Dymond, 1977).

The mean $(\mathrm{Fe}+\mathrm{Mn}) / \mathrm{Al}$ ratio of the Callovian claystone of Site 534 is $1.1 \pm 0.2$, indicating relative enrichment in $\mathrm{Fe}$ and $\mathrm{Mn}$. Highest ratios (2.3 and 1.7) occur in the upper dark, greenish gray claystone. This ratio is the same in the more oxidized brown marl, which implies that this metal enrichment cannot be explained as accumulation of pyritized radiolarian tests by winnowing. The implication is that perhaps half of the Fe and $\mathrm{Mn}$ in these sediments is derived from nondetrital sources. The average accumulation rates of the "excess" $\mathrm{Fe}$ and $\mathrm{Mn}$ is estimated as $70 \mathrm{mg} / \mathrm{cm}^{2} / 1000 \mathrm{yr}$. and $2 \mathrm{mg} / \mathrm{cm}^{2} / 1000$ yr., respectively (using the $8 \mathrm{~m} / \mathrm{m}$.y. sedimentation rate of claystone and averages of $10 \% \quad \mathrm{Fe}_{2} \mathrm{O}_{3}$ and $0.25 \%$ $\mathrm{MnO}$ ). These values approach the average accumulation rates of these metals in the metalliferous sediments near the East Pacific Rise-29 and $5.4 \mathrm{mg} / \mathrm{cm}^{2} / 1000 \mathrm{yr}$., respectively (Leinen and Stakes, 1979). Studies in the Pacific have shown that amorphous or poorly crystalized ferromanganese hydroxides precipitated from hydrothermal solutions travel far in suspension and can be a major source of $\mathrm{Fe}$ and $\mathrm{Mn}$ for sediments as much as $100 \mathrm{~km}$ from the active ridge (Heath and Dymond, 1977). Therefore, it is probable that a similar process explains the metal enrichment of the Site 534 basal unit.

The abundances of $\mathrm{Cu}, \mathrm{Ni}$, and $\mathrm{Zn}$ are also enriched relative to $\mathrm{Al}$ as compared to the ratios of typical hemi- pelagic sediments, again by a factor of two. However, the $\mathrm{Cu} / \mathrm{Fe}$ ratio $(0.0015)$ is only a third of the constant ratio (0.0046) in hydrothermal sediments of the Pacific (Heath and Dymond, 1977), whereas the $\mathrm{Ni} / \mathrm{Fe}$ and $\mathrm{Zn} /$ Fe ratios $(0.0015$ and 0.002$)$ are consistent with hydrothermal origin. The relative depletion of $\mathrm{Cu}$ is puzzling; perhaps the geochemistry of present-day hydrothermal deposits in the Pacific is different from those of the Jurassic Atlantic.

Mn values (generally in the $0.2-0.5 \%$ range) are much higher than those typical of the overlying BlakeBahama Formation, where only one analyzed sample reached $0.15 \% \mathrm{MnO}$. Murdmaa et al. (1978) note that at Site 391 the manganese content is low throughout, except for a few samples of the mid-Late Cretaceous variegated sediments in which values exceed $0.9 \%$ and an exceptional sample having $4.25 \% \mathrm{MnO}$. In this context almost all the claystones of the basal unit of Site 534 are relatively $\mathrm{Mn}$ enriched: four samples have $\mathrm{MnO}$ in the range 0.45 to $1.05 \%$, but only one of these samples $(127, \mathrm{CC})$ is from the basal sediments close to the basalts. The others are marly limestones interpreted as calcareous fines from interbedded calciturbidites. The Mn enrichments in these lime-rich beds may reflect upward mobilization from organic-rich claystone horizons and reprecipitation in the organic-poor marly limestones.

In all the samples $\mathrm{Al}_{2} \mathrm{O}_{3}$ correlates with $\mathrm{TiO}_{2}, \mathrm{~K}_{2} \mathrm{O}$, and more broadly with $\mathrm{MgO}$. These correlations point to a common source for all these oxides. The typical ratio of $\mathrm{Al}_{2} \mathrm{O}_{3}$ to $\mathrm{TiO}_{2}$ of $18: 1$ compares closely with that 
Table 2. (Continued).

\begin{tabular}{|c|c|c|c|c|c|c|c|c|}
\hline $126-2,88-90$ & $126-3,38-39$ & $126-3,99-102$ & $126-4,77-78$ & $127-1,57-58$ & $127-2,37-38$ & $127-3,11-13$ & $127-4,8-10$ & $127, \mathrm{CC}(10-11)$ \\
\hline $\begin{array}{c}\text { Green } \\
\text { calcareous claystone }\end{array}$ & $\begin{array}{c}\text { Green } \\
\text { calcareous claystone }\end{array}$ & $\begin{array}{c}\text { Grayish } \\
\text { brown marl }\end{array}$ & $\begin{array}{c}\text { Dusky brown } \\
\text { marl }\end{array}$ & $\begin{array}{c}\text { Dusky brown } \\
\text { marl }\end{array}$ & $\begin{array}{l}\text { Dusky brown } \\
\text { marl }\end{array}$ & $\begin{array}{l}\text { Reddish } \\
\text { claystone }\end{array}$ & $\begin{array}{l}\text { Reddish } \\
\text { claystone }\end{array}$ & $\begin{array}{c}\text { Dusky brown } \\
\text { marl }\end{array}$ \\
\hline 59.35 & 59.35 & 56.56 & 57.01 & 60.24 & 56.91 & 62.85 & 61.3 & 57.37 \\
\hline 12.16 & 12.16 & 11.12 & 13.33 & 11.98 & 12.64 & 12.65 & 11.5 & 10.27 \\
\hline 11.11 & 11.11 & 9.85 & 9.23 & 8.74 & 6.96 & 10.12 & 9.6 & 7.47 \\
\hline 3.78 & 3.78 & 3.53 & 3.44 & 3.18 & 3.22 & 3.52 & 3.7 & 3.25 \\
\hline 9.38 & 9.37 & 15.58 & 12.04 & 11.72 & 15.09 & 5.54 & 9.2 & 17.13 \\
\hline 0.73 & 0.73 & 0.56 & 0.66 & 0.67 & 0.80 & 0.81 & 0.8 & 0.57 \\
\hline 2.65 & 2.65 & 2.66 & 3.26 & 2.99 & 3.19 & 3.10 & 2.8 & 2.49 \\
\hline 0.69 & 0.69 & 0.59 & 0.71 & 0.62 & 0.67 & 0.76 & 0.6 & 0.53 \\
\hline 0.20 & 0.20 & 0.27 & 0.25 & 0.24 & 0.34 & 0.16 & 0.2 & 0.57 \\
\hline 0.11 & 0.11 & 0.05 & 0.11 & 0.08 & 0.26 & 0.13 & 0.0 & 0.04 \\
\hline 100.16 & 100.16 & 100.78 & 100.05 & 100.45 & 100.07 & 99.64 & 100.1 & 99.67 \\
\hline & 67 & 99 & & & & 111 & 76 & \\
\hline & 103 & 82 & & & & 88 & 79 & \\
\hline & 199 & 175 & & & & 110 & 90 & \\
\hline & 23 & 20 & & & & 22 & 21 & \\
\hline & 144 & 84 & & & & 40 & 62 & \\
\hline & 162 & 106 & & & & 112 & 73 & \\
\hline & 216 & 229 & & & & 226 & 205 & \\
\hline & 104 & 110 & & & & 117 & 112 & \\
\hline & 124 & 108 & & & & 144 & 122 & \\
\hline & 11 & 9 & & & & 11 & 11 & \\
\hline & 210 & 154 & & & & 349 & 192 & \\
\hline & 28 & 21 & & & & 13 & 24 & \\
\hline & 10 & 10 & & & & 10 & 12 & \\
\hline & 57 & 83 & & & & 43 & 54 & \\
\hline & 55 & 64 & & & & 62 & 40 & \\
\hline & 28 & 29 & & & & 29 & 22 & \\
\hline & 34 & 30 & & & & 32 & 25 & \\
\hline
\end{tabular}

of claystones and marls in the overlying Early Cretaceous Blake-Bahama Formation (Robertson and Bliefnick, this volume). The elemental $\mathrm{Al} / \mathrm{Ti}$ ratio of 16 is much lower than in terrestrial shales (range of 28-37) or in typical Pacific pelagic sediments (range of about $30-50$ ); it is closer to the 25 to 16 mean range of DSDP Site 317 , which was interpreted as having a contribution from a local basalt source (all values from Donnelly and Wallace, 1976a and b). Bostrom (1977) proposed that $\mathrm{Al} / \mathrm{Ti}$ ratios of less than 30 generally indicate a basaltic volcanic contribution to the sediment. However, Bostrom (1973, p. 163) had earlier cited Al/Ti ratios of 17.5 for average shales and implied that a 12 to 20 range in pelagic sediments reflected negligible input of basaltic matter. Murdmaa (1978) used these earlier values to interpret the $\mathrm{Al} / \mathrm{Ti}$ ratio range of 18 to 30 of the red Upper Jurassic marls at DSDP Site 391 as typical of terrigeneous sediment. J. I. Drever (personal communication, 1982) noted the abundance of biotite-chlorite flakes in numerous horizons within the basal unit of Site 534 and suggested that periodic volcanic ash falls could best explain these occurrences. However, only two petrographic thin sections within this basal unit had possible rare volcaniclastic fragments (see Table 1), and the concentration of smectite clays is lower than in the overlying units (Chamley et al., this volume). Whereas neither of these observations rule out a significant volcaniclastic contribution, we believe this contribution cannot be as important as the $\mathrm{Al} / \mathrm{Ti}$ ratio would indicate. ${ }^{4}$

\footnotetext{
${ }^{4}$ The importance seems to depend on the choice of cited references.
}

In summary, we interpret the chemistry of this basal unit to reflect an organic-rich terrigenous clastic input with significant enrichment in metals, probably derived from hydrothermal exhalations at the nearby active ridge, and perhaps a minor contribution from volcanic ash. Biogenic pelagic input is minor except in the basal cores (calcareous) and scattered horizons in the claystones (siliceous).

\section{Discussion and Interpretation}

Callovian paleogeography and oceanography near Site 534. At the time of the deposition of the basal sediments, Site 534 was equidistant between the African continental margin and the Blake Spur Ridge. Because the North American continental margin was at least another $300 \mathrm{~km}$ beyond the Blake Spur across the Blake Plateau basin-carbonate platform, the closest known exposed continental land mass would have been the $\mathrm{Pa}$ leozoic fold belts and platform of the Liberia Upper Volta Massif of western North Africa about $200 \mathrm{~km}$ away (Fig. 4). The Senegal Basin, Bahama Banks, and outer Blake Plateau were shallow-water carbonate platforms during the Late Jurassic, but the middle Callovian sedimentation is not yet documented (Jansa and Wiedmann, 1982). The late Middle Jurassic in the Bahama-Cuba-Blake Plateau platform may be a widespread unconformity on an Early to Middle Jurassic clastic shelf (Schlager and Ginsburg, 1981). A rapid rise in global eustatic sea level commences in the early Callovian and crests in the late Callovian (Hallam, 1978; Vail and Todd, 1980). It is therefore plausible that clastic detritus 
was being shed into the south end of the narrow Atlantic seaway from all land masses during the early Callovian and mainly from the African highland in the late Callovian.

The $10^{\circ} \mathrm{N}$ paleolatitude of the site would place it under the east-to-west equatorial current flow and tradewind belt, and under the high productivity zone off the African coast-if the oceanographic behavior of the contorted narrow seaway resembled a normal ocean. Exchange of intermediate and deep waters with the Western Tethys via a seaway between Iberia and Africa or with the Pacific-Caribbean via a gap between the Guinea nose and Bahama Banks or via a vanished seaway-trough across present-day Florida or Florida Strait are purely conjectural given our present knowledge, and our guess is that any mid- or deep-water exchange at this stage was not significant. Bottom-water circulation, and perhaps surface circulation as well, in the vicinity of Site 534 was probaly mainly an internal feature of the Atlantic seaway and only marginally affected by exchange with other oceans.

Clay and silt from the surrounding land masses around this southern end of the Atlantic were important constituents of the sediments. Borne by nepheloid drift, winds and surface currents, this terrestrial detritus rained down at Site 534 (quartz-rich silt comprises $10-15 \%$ of the claystone, reflecting the relative proximity of the sources). Direct turbidite input from the North American shelf was dammed behind the Blake Spur Ridge in the early stages (see Sheridan et al., this volume). When the barrier was breached in the late Callovian, the turbidites that reached Site 534 were lime-rich.

Subsidence and $C C D$. During the estimated 5-m.y. interval between the deposition of the basal brown marl and the carbonate-depleted claystone found in Cores 120 through 122, the Site rapidly subsided about $300 \mathrm{~m}$ (to about a $2800-3100-\mathrm{m}$ paleodepth ${ }^{5}$ ). This subsidence may have lowered the sediment surface below the CCD during the Callovian, or the CCD could have risen. This subsidence, plus possible rise in the CCD, would explain the progressive disappearance of pelagic bivalve shells, then nannofossils within the claystones. (Evidence for a general rise in the CCD in the Atlantic-Tethys system in the early Callovian is presented in later parts of this chapter.) In addition, there could have been a change in the accumulation rate of the clastic component.

Fertility of surface waters. The dominant microfossils in the claystone are radiolarians. In present-day oceans, siliceous sediments are found primarily in zones of high fertility and upwelling close to the convergence areas near $60^{\circ} \mathrm{S}$ and $60^{\circ} \mathrm{N}$ latitudes (diatoms), near the equator (radiolarians) and in semirestricted basins with upwelling near continental margins, such as the Gulf of California (diatoms and radiolarians) (Jenkyns, 1978).

\footnotetext{
${ }^{5}$ We estimated paleodepths using the method of Tucholke and Vogt (1979). To compute the depth of the sediment surface at a given time, two-thirds of the total sediment thickness at that time is added to the basement depth on their empirical age-depth curve for the Atlantic. The elapsed time is estimated using the Van Hinte (1976) absolute time scale for the Jurassic. No effort was made to correct for basement topography, variable sediment compaction, or the spreading rate. We used $2700 \mathrm{~m}$ as the initial depth, but Sclater et al. (1971) show that the averaqe height of a ridge is a function of spreading rate-fast spreading ridges are deeper. As a result , there is at least a $200-\mathrm{m}$ uncertainty in any of our estimates.
}

During the Callovian, Site 534 would have been near the edge of an equatorial belt of high fertility stretching westward from an upwelling zone off the African coast. Throughout the Jurassic the Atlantic would have been a semirestricted basin. Fertility depends on the upwelling of nutrients, which is determined by wind patterns. Therefore, if moderately strong trade winds existed in the Callovian, Site 534 could have been below high-fertility surface waters. The preservation of abundant radiolarians in numerous layers within the claystone, coupled with the relative abundance of fish remains, is consistent with, though not proof of, high fertility of the surface waters.

Bottom topography. The seismic reflection profiles show that Site 534 basal sediments were deposited on a slope. The present hummocky basement topography is interpreted to be the result of an originally faulted topography near the spreading axis (Fig. 2). Marl intraclasts within the claystones indicate at least localized redeposition from above the CCD, but the seismic profiles show no obvious topographic high near Site 534, suggesting that basement faulting may have continued during or after deposition of the Callovian. In this context it is of interest that the cores show synsedimentary slumps, shear planes, and redeposited intraclasts, which all attest to syndepositional movement. Also, the beds are generally inclined at $10^{\circ}-$ very much more than the expected depositional repose of such fine-grained sediments. Inclinations return to horizontal upon the arrival of lime-rich turbidites in the late Callovian-early Oxfordian, which leveled the topography of the region. A drilling artifact appears to be ruled out by the measured drill-string deviation of only $2^{\circ}$. Therefore, the tilting could be due only to (1) major slumping or (2) tilting of major fault blocks.

Bottom currents. The seismic reflection profiles also reveal a hummocky, uneven appearance of the basal unit in strong contrast to the even basin-leveling turbidites of reflector D. Sheridan et al. (this volume) consider this to be the seismic signature of contourite deposits.

Sedimentary structures in the Callovian claystone are suggestive of bottom-current activity. The best evidence of this activity is the lenticular shape of many of the radiolarian sand layers considered to be a product of current winnowing. Other slightly more ambiguous structures are parallel lamination, common "streaky" texture, cross-laminations (not part of larger slump features described earlier), and small lenses with sharp truncations top and bottom. Added together, there is considerably more evidence of moderate bottom-current activity than at the "classic" contourite deposit of Site 533 (see Site 533 report, this volume).

Origin of radiolarites. Radiolarians are the only important microfossil in the greenish gray claystone and generally comprise less than $5 \%$ of the total volume. They are all replaced by pyrite, and, if the skeleton is fairly intact, it is filled by calcite spar. Radiolarians are not found in the underlying, more oxidized, dusky brown marl, which indicates that radiolarians were not preserved in the sediment unless the tests were replaced by pyrite. Presumably, the influx of radiolarians was much 
greater, and only a small percentage were preserved owing to the reducing conditions in the organic-rich claystone. A similar favored preservation is found in the Cretaceous Atlantic black shales (Jenkyns, 1980a).

This pyrite replacement and calcite-filling must have occurred very early, because in one thin section (Sample 534A-124-1, $79 \mathrm{~cm}$ ) there are broken calcite-spar fillings that are separate from the fragments of pyritized tests. This thin section suggests the following history: (1) rain of radiolarians to the seafloor, (2) probable dissolution of most radiolarians and replacement of those remaining by pyrite under the reducing conditions in the claystone, (3) exhumation, transport, and breaking of the pyritized, calcite-filled radiolarians by currents, and (4) reburial.

The radiolarian sand layers are distinctly different. The radiolarians are generally replaced and filled by silica (spherulitic chalcedony) and rarely have pyrite replacements or calcite fillings. These high concentrations of radiolarian tests have favored local silica saturation in the interstitial water, which allowed opal dissolutionsilica reprecipitation to occur. All of this silica is now quartz with no trace of an opal-CT (cristobalite) precursor. In the claystone immediately bordering radiolarian sand layers, there is no silicification.

How were these layers of concentrated radiolarians formed? McCave (1979) described very similar radiolarian sand layers in organic-rich, greenish black, late $\mathrm{Ce}$ nomanian claystones at Sites 386 and 387 in the western North Atlantic. He outlines three possible origins of these layers:

(1) Episodic high radiolarian influx from productivity blooms. Seasonal blooms would not create layers 1-cm thick, so longer productivity episodes lasting decades to centuries were postulated. McCave correlates this productivity with high input of organic material (black mudstone layers). At Site 534, however, the radiolarian sands occur independently of the black carbonaceous layers, which have carbon from terrestrial plant debris (Habib, this volume).

(2) Episodic volcanic ash falls that raised the dissolved silica concentration in the near-surface sediments, enabling preservation of radiolarian tests. However, McCave noted there is no evidence of ash falls associated with radiolarian layers, which is also the case at Site 534.

(3) Turbidity currents or sand flows carrying radiolarian-rich sediment from local highs where silica dissolution was less effective. McCave noted that the lack of grading of the radiolarian sands and the independent occurrence of turbidites of graded mud clasts lacking abundant radiolarians (also the case at Site 534) made radiolarian sand turbidites an unlikely explanation. However, grading of radiolarian sands would not be expected because the limited size range of radiolarian tests displays similar hydraulic behavior (Barrett, 1979), and dissolution at the sediment/water interface may have removed any lighter, more delicate tests in the upper part of the radiolarian layer (M. Baltuck, personal communication, 1982).
A fourth possibility considered by Leg 76 sedimentologists was that bottom currents periodically winnowed the sediment. Supporting evidence is the lenticular form of many radiolarian sand beds with some scoured bases and the current features in the greenish claystone microfacies. However, silicified radiolarians are completely absent from the adjacent claystones. An explanation is that radiolarians settled more or less continuously onto the seafloor, but were periodically winnowed to produce the radiolarite lenses. During diagenesis the levels of dissolved silica within these lenses were sufficient to infill and preserve shells. Notably, many of the tests are broken and abraded and are without spines. The silica filling of the tests would have come either from this fine spine material or from selective dissolution of more soluble species. Meanwhile, the scattered radiolarian tests in the silica-depleted mudstones (unless preserved by pyritization early in diagenesis) dissolved, leaving no trace after compaction.

Origin of black shales. One of the most interesting discoveries at Site $\mathbf{5 3 4}$ was the existence of Callovian black shales. In the Cretaceous, distinct black shale events have been attributed to anoxic bottom conditions caused by stratified oceans and sluggish bottom waters (Schlanger and Jenkyns, 1976; Arthur and Natland, 1979; Jenkyns, 1980a). In the Callovian, the organic matter is dominantly terrigenous (Site 534 report and Habib, this volume); the sedimentary structures and seismic reflection signature indicate bottom circulation, although the indications of bottom life are rare.

Moderate bottom currents recorded at Site 534 are not incompatible with low, dissolved-oxygen levels in the near-surface sediments (as implied by early replacement of radiolarian tests by pyrite), provided that relatively high concentrations of organic material were buried. If the terrestrial organic material was resistant to immediate decomposition, a stratified anoxic ocean is not required. The retention of organic matter in the sediment depends mainly on net subsurface preservation, so that where organic input is high, diagenetic anoxicity can persist even in quite oxidizing circulating waters. Similarly, Robertson and Bliefnick (this volume) relate the Lower Cretaceous black shales within the Blake-Bahama Formation to high levels of terrigenous input onto a seafloor that was never reducing except beneath or just above the surface. This does not prove the Callovian ocean was not stratified and anoxic, but these conditions certainly are not necessary. The organic-rich claystones are caused by a high input of terrestrial organic material into the basin; additional contributing oceanographic factors are speculative at this point.

The presence of phosphate concretions and glauconite in the claystone is typical of diagenetic processes within black shales (Krumbein and Garrels, 1952; McRae, 1972; Jenkyns, 1978). Glauconite, conventionally considered to form at rather shallow depths $(75-500 \mathrm{~m})$, has been discovered in situ at depths of 1000 to $2000 \mathrm{~m}$ off Central America and possibly at depths of $6000 \mathrm{~m}$ (Odin and Stephan, 1982). The requisite conditions for 
glauconitization (plentiful iron ions, slow sedimentation, influx of sand-sized bioclasts, circulation of bottom water, and moderate to low dissolved oxygen) existed during deposition of the basal claystone unit at Site 534, and the glauconite is believed to be formed in situ.

\section{Variegated Claystones (Oxfordian) Cores 111 through 119 (1495.5-1572.0 m sub-bottom)}

\section{Macroscopic Features}

This unit has interbedded dark-colored claystones (10-15\% average $\mathrm{CaCO}_{3}, 5 \%$ terrigeneous silt) of three basic hues: "reddish," "'greenish," and "black." These three types occur in bands 1- to 5-cm thick with diffuse or sharp contacts. The most common sequence is a black basal layer that has a sharp upper contact with a thin horizon of greenish, laminated, calcareous, silty clay, overlain by a reddish layer with greenish mottles, then an uneven transition to a greenish clay with Chondrites burrows, terminating at a sharp upper contact with another black layer (Fig. 14A).

Although there are exceptions to this generalized sequence, the interpretation of the shipboard sedimentologists was that the black layers are in situ pelagic sedimentation and the reddish layers are claystone turbidites. The greenish layers are thought to have formed by reduction of former red zones, especially near the contacts with the organic-enriched black layers. Alternative ideas of periodic changes in dissolved-oxygen level or input of organic material fail to explain the observed bioturbation or numerous graded silt layers.

Interbedded with the claystones are greenish gray, marly, pelmicrite limestones, which are most abundant in the lower portion. This abundance led to the subdivision of the variegated claystone interval into subunits $7 \mathrm{a}$ and $7 \mathrm{~b}$ by the shipboard sedimentologists. These lime-rich turbidites are described later.

Extremely poor recovery $(10 \%)$ prevents determination of the total thickness of the claystones (excluding lime-rich turbidites), but the recovered proportions suggest 50 to $60 \mathrm{~m}$ of claystones. The estimated time span is about $6 \mathrm{~m} . y$., implying a sedimentation rate between 8 and $10 \mathrm{~m} / \mathrm{m} . y$. However, the redeposited reddish and greenish claystones comprise approximately $75 \%$ of the unit, implying that the in situ black claystones accumulated more slowly, possibly about 2 to $3 \mathrm{~m} / \mathrm{m}$.y.

On the basis of the change in character of nannofossil assemblages and preservation, A. Medd (personal communication, 1981) proposed a hiatus between the variegated claystone unit and the underlying dark green silty claystone. This hiatus would fall in the early Oxfordian, based on nannofossil biostratigraphy and palynology (Habib and Drugg, this volume). A hiatus is indeed supported by the sudden change in claystone facies, however, poor recovery allows up to $10 \mathrm{~m}$ of nonrecovery for this interval.

The bedding is horizontal, in sharp contrast to the underlying greenish black claystone unit. There is no evidence of bottom currents or slumping. Chondrites burrows are present, primarily in the upper portions of some claystone turbidites.

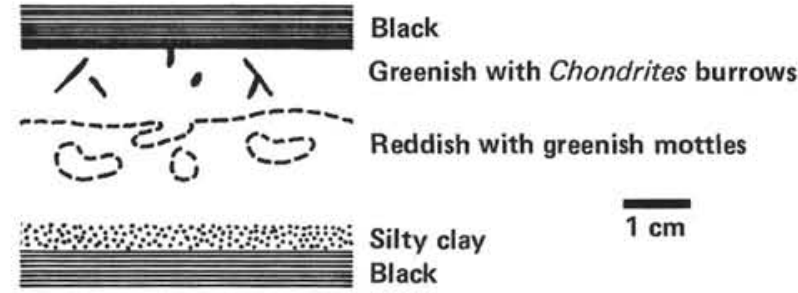

A

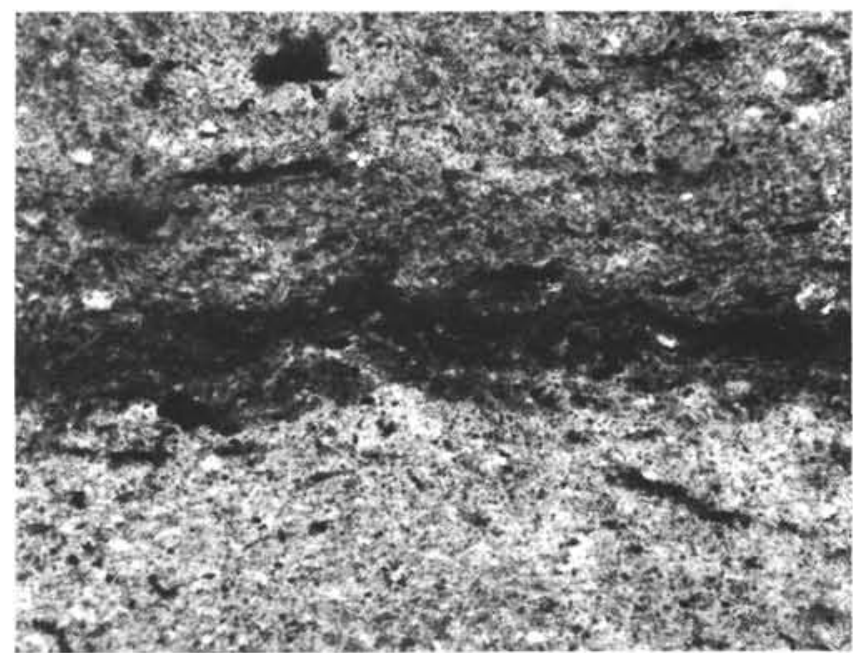

B

Figure 14. A. Common sequence in the variegated claystone unit (?Oxfordian) of a black basal layer having a sharp upper contact with a thin horizon of greenish, laminated, calcareous, silty clay, overlain by a reddish layer with greenish mottles, then an uneven transition to a greenish clay with Chondrites burrows, terminating at a sharp upper contact, with another black layer. B. Photomicrograph of a typical thin section-1.7 mm across-of the dark variegated claystone unit (534A-114-1, $17 \mathrm{~cm}$ ). (A "gray" claystone is overlain by a "green" claystone with a black wispy zone between. Terrigenous silt is abundant, no bioclasts of any type are present, and the clay minerals display uniform optical orientation; ?Oxfordian in age. [Note that the "up" orientation of this thin section was lost during preparation.])

\section{Microfacies and Chemistry}

The main characteristic of these claystones is the virtual absence of any microfossils (Table 3). There seem to be no significant compositional differences among the various color types of claystone except for minor changes in abundance of opaques (mainly organics) and degree of parallel orientation of the fabric (Fig. 14B). Nannofossil abundance (3-25\% range) showed no consistent variation among the claystones. Fine silt (5-10\%) of quartz and mica composes to 3 to $6 \%$ of the claystones except for thin horizons of silty claystone. Phosphatic fish remains compose 0 to $3 \%$. One thin section (Sample 534A-113-1, $14 \mathrm{~cm}$ ) has rare spheres of calcite spar, probably replaced radiolarians.

The carbonate content of the claystone ranges from 0 to $33 \%$, half the analyses being below $3 \%$. Of the 8 analyses, three are in the 30 to $33 \%$ range, and the rest below $10 \%$. This suggests that these claystones were deposited close to the CCD. The more carbonate-rich intervals represent either fluctuations in the $\mathrm{CCD}$ or, 
Table 3. Microfacies of Hole 534A Oxfordian claystones.

\begin{tabular}{|c|c|c|c|c|c|c|c|}
\hline \multirow{2}{*}{$\begin{array}{c}\text { Sample } \\
\text { (core-section, } \\
\mathrm{cm} \text { from top of section) }\end{array}$} & \multirow[b]{2}{*}{ Lithology } & \multirow[b]{2}{*}{ Bioclasts } & \multicolumn{4}{|c|}{ Silt-sized components $(\%)$} & \multirow[b]{2}{*}{ Comments } \\
\hline & & & Quartz & Mica & Opaques & Phosphate & \\
\hline $113-1,14$ & Green marl & $\begin{array}{l}\text { Rare calcified } \\
\text { radiolarians }\end{array}$ & 1 & 2 & 5 & 3 & $\begin{array}{c}\text { Abrupt basal } \\
\text { contact to } \\
\text { limestone. }\end{array}$ \\
\hline $114-1,17$ & Variegated clay & None & 2 & 3 & 4 & tr & $\begin{array}{l}\text { Silt is very fine } \\
(\leq 10 \mu \mathrm{m}) ; \\
\text { no signifi- } \\
\text { cant varia- } \\
\text { tion among } \\
\text { claystones. }\end{array}$ \\
\hline $115-1,17$ & $\begin{array}{l}\text { Reddish brown } \\
\text { clay }\end{array}$ & None & 2 & 4 & 2 & 3 & $\begin{array}{l}\text { Amorphous } \\
\text { clay-size } \\
\text { organics } \\
(2 \%) .\end{array}$ \\
\hline $117-1,13$ & $\begin{array}{c}\text { Dusky red } \\
\text { marl }\end{array}$ & None & 2 & 2 & 5 & 0 & $\begin{array}{l}\text { Clay-size } \\
\text { organics } \\
(2 \%) .\end{array}$ \\
\hline
\end{tabular}

Note: $t r$ indicates trace.

more possibly, redeposition from slightly shallower water depths.

Organic carbon ranges from 0.2 to $3.9 \%$, with three of the four analyses exceeding $1.0 \%$. The higher organic contents appear to correlate with low carbonate values.

Eight samples were analyzed for major element chemistry (Cores 111-118 in Table 4). As predicted from the petrology, the variegated claystone has a low terrigenous component. $\mathrm{Mn}$ is relatively enriched, which may indicate a hydrothermal source. Chamley et al., (this volume) conclude that minor $\mathrm{Fe}$ and $\mathrm{Mn}$ enrichment has occurred from sources at the distant active ridge. Several of the samples display high $\mathrm{Ti} / \mathrm{Al}$ ratios relative to other units. The $\mathrm{Ti}$ does not correlate with $\mathrm{Fe}, \mathrm{Mg}$, or $\mathrm{K}_{2} \mathrm{O}$. A high $\mathrm{Ti} / \mathrm{Al}$ source is indicated, possible a basaltic contribution. The clay mineralogy is similar to that of the Callovian greenish black silty claystone (Chamley et al., this volume).

\section{Discussion and Interpretation}

Claystone turbidites. During the Oxfordian, thinbedded distal claystone turbidites were able to reach the Site. In marked contrast to claystone turbidites of the Early Cretaceous Blake-Bahama Formation (Robertson and Bliefnick, this volume), these claystone turbidites possess a lower organic matter content than the background pelagic sedimentation. The source area was thus above the surrounding seafloor but well below the oxygen-minimum zone. The variable $\mathrm{CaCO}_{3}$ content suggests derivation near the $\mathrm{CCD}$. The possible source areas are the Blake Spur Ridge (110 km west) or the region of the spreading ridge beyond and above the seismic reflector D pinch-out between M-27 and M-28 (about 50-80 km east) (Sheridan et al., this volume). A higher, second source supplied the lime-rich turbidites, possibly from the Blake Plateau area (discussed in a later section).

Diagenesis and black shales. The variegated character of this unit reflects patchy oxidation and reduction after deposition. Chondrites burrows show that bottom waters were not anoxic.

The sediments are relatively rich in organic matter. Indeed, if the reddish-greenish claystone turbidites input is subtracted, the remaining pelagic sediment is continuing black-shale deposition. However, unlike the mostly terrigenous input of the Callovian, Habib (this volume) shows that from the early Oxfordian to late Berriasian much of the recognizable organic matter is of

Table 4. Chemistry of Cat Gap Formation Hole 534A samples (on a $\mathrm{CO}_{3}$-free basis).

\begin{tabular}{lrrrrrrrrrrr}
\hline $\begin{array}{c}\text { Sample } \\
\text { (core-section, } \\
\text { cm interval) }\end{array}$ & $\mathrm{SiO}_{2}$ & $\mathrm{Al}_{2} \mathrm{O}_{3}$ & $\mathrm{Fe}_{2} \mathrm{O}_{3}$ & $\mathrm{MgO}$ & $\mathrm{CaO}$ & $\mathrm{Na}_{2} \mathrm{O}$ & $\mathrm{K}_{2} \mathrm{O}$ & $\mathrm{TiO}_{2}$ & $\mathrm{MnO}$ & $\mathrm{P}_{2} \mathrm{O}_{5}$ & Total \\
\hline $91-3,100-101$ & 46.15 & 11.38 & 4.19 & 2.52 & 31.12 & 0.62 & 2.07 & 0.54 & 0.05 & 0.16 & 98.79 \\
$95-4,46-47$ & 45.11 & 9.89 & 4.06 & 2.43 & 34.91 & 0.61 & 1.87 & 0.45 & 0.20 & 0.08 & 99.56 \\
$95-4,50-61$ & 45.21 & 10.47 & 6.64 & 2.93 & 31.21 & 0.72 & 1.84 & 0.51 & 0.11 & 0.07 & 99.71 \\
$99-3,93-94$ & 55.36 & 14.29 & 9.18 & 3.85 & 13.23 & 1.15 & 2.48 & 0.69 & 0.04 & 0.07 & 100.35 \\
$100-2,75-77$ & 47.60 & 13.38 & 5.05 & 3.37 & 26.13 & 0.93 & 2.44 & 0.57 & 0.33 & 0.07 & 99.86 \\
$100-3,54-56$ & 47.27 & 12.15 & 7.50 & 3.14 & 25.22 & 0.88 & 2.22 & 0.56 & 0.17 & 0.07 & 99.19 \\
$102-2,80-82$ & 57.11 & 12.93 & 8.44 & 3.34 & 12.83 & 1.03 & 2.84 & 0.61 & 0.07 & 0.07 & 99.27 \\
$102-2,89-90$ & 44.96 & 8.10 & 5.51 & 1.91 & 36.58 & 0.58 & 1.64 & 0.42 & 0.14 & 0.09 & 99.90 \\
$101-5,76-76$ & 53.78 & 13.54 & 8.01 & 3.24 & 16.43 & 1.07 & 2.81 & 0.62 & 0.12 & 0.08 & 99.70 \\
$103-1,52-53$ & 42.07 & 11.28 & 7.50 & 3.49 & 30.99 & 0.84 & 2.29 & 0.59 & 0.26 & 0.10 & 99.40 \\
$104-2,130-132$ & 11.31 & 2.73 & 2.15 & 1.09 & 75.11 & 0.03 & 0.38 & 0.16 & 0.38 & 0.05 & 93.40 \\
$110-1, \mathrm{CC}$ & 44.00 & 10.14 & 7.27 & 2.31 & 32.62 & 0.71 & 2.22 & 0.56 & 0.12 & 0.08 & 100.01 \\
$111-1,19-21$ & 39.24 & 9.55 & 5.73 & 2.50 & 39.75 & 0.72 & 1.65 & 0.71 & 0.17 & 0.13 & 100.15 \\
$112-1,30-32$ & 44.09 & 10.28 & 6.29 & 2.51 & 32.78 & 0.73 & 1.82 & 0.81 & 0.17 & 0.14 & 99.61 \\
$113-1,35-37$ & 24.09 & 6.14 & 4.63 & 1.95 & 58.82 & 0.26 & 0.78 & 0.33 & 0.35 & 0.12 & 97.46 \\
$114-1,27-29$ & 48.64 & 11.53 & 7.41 & 2.57 & 26.13 & 0.76 & 1.89 & 0.98 & 0.23 & 0.15 & 100.30 \\
$115-1,12-14$ & 40.55 & 8.10 & 4.15 & 2.03 & 41.96 & 0.44 & 1.32 & 0.46 & 0.54 & 0.09 & 99.64 \\
$115-1,79-80$ & 41.55 & 8.62 & 6.24 & 2.20 & 37.96 & 0.57 & 1.32 & 0.57 & 0.51 & 0.16 & 99.69 \\
$116-1,45-46$ & 51.64 & 10.83 & 8.29 & 2.59 & 22.31 & 0.81 & 1.91 & 0.76 & 0.24 & 0.16 & 99.55 \\
$118-1,7-9$ & 39.51 & 8.32 & 5.34 & 2.42 & 39.81 & 0.46 & 1.50 & 0.56 & 0.29 & 0.12 & 98.26 \\
$120-1,68-69$ & 74.09 & 8.32 & 10.15 & 2.98 & 1.70 & 0.42 & 1.38 & 0.38 & 0.02 & 0.05 & 99.47 \\
$121-1,9-11$ & 47.12 & 9.88 & 5.02 & 2.70 & 31.51 & 0.65 & 1.73 & 0.54 & 0.35 & 0.082 & 99.58 \\
\hline
\end{tabular}


marine origin, with only short intervals of carbonized terrestrial material.

The easiest way to explain the absence of radiolarian tests is that bottom currents were less active, hence concentration of radiolarians by winnowing did not occur. The individual dispersed tests dissolved, but activity of dissolved silica was insufficient to promote diagenetic silica precipitation. The lack of pyrite replacement of the tests suggests that dissolution occurred nearly simultaneously with deposition. Also, probably the influx of radiolarians was reduced as the Site moved northward in latitude out of the equatorial high fertility zone. The paleolatitude at the end of the Oxfordian was about $15^{\circ} \mathrm{N}$ (calculated from the North American polar wander path in Steiner [in press] and supported by the paleomagnetic inclinations of these sediments [Ogg, this volume]).

\section{Greenish Gray Marl (Kimmeridgian-?Oxfordian) Cores 104 through 110 (1437.0-1495.5 m sub-bottom)}

\section{Macroscopic Features}

The marl (averaging $30 \% \mathrm{CaCO}_{3}$ ) of this unit is predominately greenish gray, but there are several horizons of brownish red, especially in the lower portion. Approximately half of this interval consists of limestone turbidites (described later), and it appears that brownish red marl is most common in sections with a relatively lower abundance of turbidites. No major composition differences were noted between the two marl color types, which suggests only reduction-oxidation is involved. The darkest greenish gray layers contain rare pyrite and appear to have a lower carbonate content.

The marl is laminated to moderately bioturbated (Chondrites burrows mainly). Many discontinuous layers of fibrous spar calcite occur within the marls of Cores 104 and 108, and in Core 104 these are formed by the coalescing of prismatic overgrowths on small pelagic bivalve shalls ("filaments") (Fig. 15). This texture is called "beef" in the Lias of southern England.

Accumulation rate of this marl unit is difficult to estimate because of poor recovery and uncertainty of age. Based on the recovery, the total thickness of the marl component is 25 to $35 \mathrm{~m}$. The age interval is estimated as 3 to $5 \mathrm{~m}$.y., giving sedimentation rates ranging from 5 to $12 \mathrm{~m} / \mathrm{m}$.y.

\section{Microfacies and Chemistry}

Fine pelagic bivalve shell fragments (often called "filaments") are abundant (5-15\%) in the upper portion of the marl unit (Cores 104-106), but not in the lower portion (Cores 108-110). These fragments normally have extensive overgrowths of very elongate calcite crystals perpendicular to the shell axis, a feature best developed in relatively clay-rich horizons (Fig. 16). Calcified radiolarians are abundant in micrite-rich layers and very rare in other horizons. The density of bioclasts is extremely variable in the few available thin sections and smear slides of the marl (Table 5).

The marl has up to $50 \%$ microspar, implying extensive carbonate diagenesis. Silt-sized terrigenous clastics

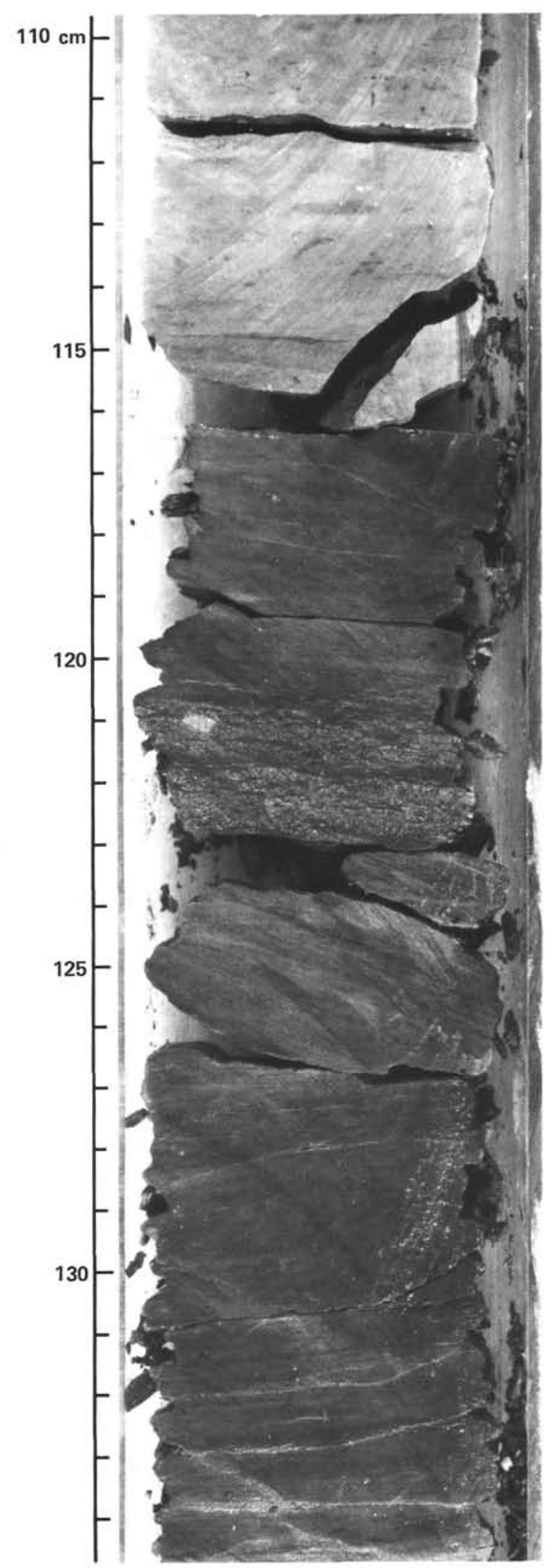

Figure 15. Reddish brown marl interval in the Kimmeridgian(?) greenish gray marl unit, Sample 534A-104-3, 100-135 cm. ("Beef" texture between 121 and $123 \mathrm{~cm}$ is prismatic overgrowths of calcite on small pelagic bivalve shells ["filaments"]. Gray limestone at $110-116 \mathrm{~cm}$ is the base of a calciturbidite bed.) 


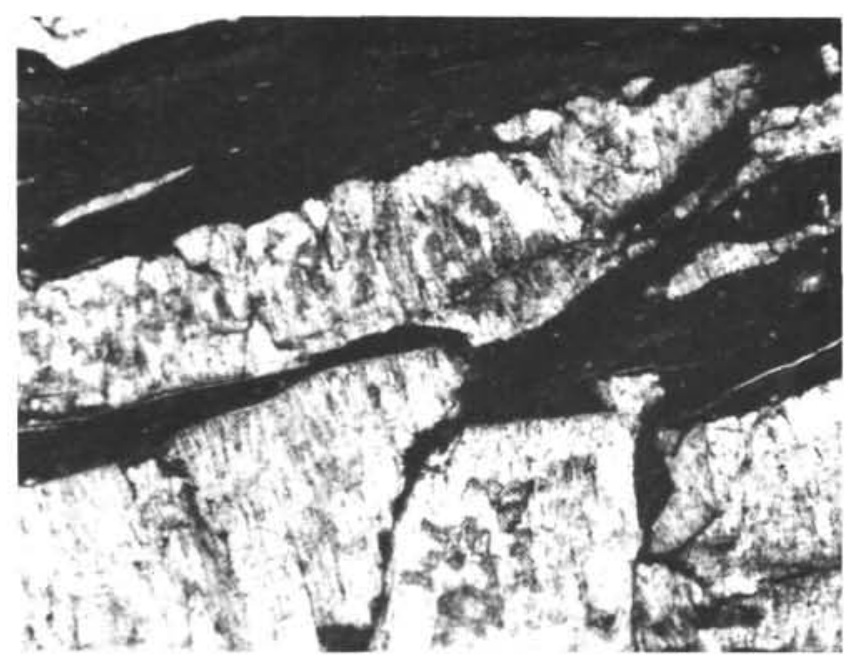

Figure 16. Photomicrograph of "beef"' texture in Sample 534A-104$4,73 \mathrm{~cm}$. (Small pelagic bivalve shells have prismatic calcite overgrowths. Commonly these overgrowths are only on one side of a shell and merge with opposing overgrowths from another shell. Matrix is a red marl interval in the Kimmeridgian(?) greenish gray marl unit. Photomicrograph is $1.7 \mathrm{~mm}$ in width.)

are commonly about $2 \%$, rarely up to $10 \%$. Organic material is rare $(1-2 \%)$. The marl appears to have micrite pellets in some horizons.

The carbonate content of the marl varies between 17 and $50 \%$, with no obvious trend through the unit. Aragonite seen in one smear slide (Sample 534A-104-4, $137 \mathrm{~cm}$ ) was confirmed by X-ray diffraction (Sample $534 \mathrm{~A}-104-4,139 \mathrm{~cm}$ ) in a brownish red marl zone near the top of the unit. (This aragonite-rich red-marl interval is within $10 \mathrm{~cm}$ of the base of an overlying limestone turbidite, so there is a possibility that this turbidite buried the marl before normal aragonite dissolution within the sediment could take place. Unfortunately, no other samples were analyzed in this core or the adjacent one.) Organic carbon values were less than $0.3 \%$ throughout. The dominant clay mineral is smectite, with significant amounts of illite (up to $30 \%$ ), chlorite (up to $10 \%)$, mixed-layer clays $(5 \%)$, and traces of kaolinite (Chamley et al., this volume).

\section{Discussion and Interpretation}

Age. There is a major discrepancy between the two main biostratigraphic methods for estimating the age of the greenish gray marl unit. The nannofossil zonation tentatively places the top cores (104 and 105) in the Kimmeridgian and the rest in the Oxfordian (A. Medd, personal communication, 1981). Palynology determinations place the entire unit within the Kimmeridgian, with the Tithonian/Kimmeridgian boundary possibly within Core 104 (Habib, this volume).

Magnetostratigraphy places the Tithonian/Kimmeridgian boundary within Core 102 and tentatively assigns Cores 102 through 108 to the Kimmeridgian (Ogg, this volume).

A basal unconformity or hiatus is suggested by $\mathrm{A}$. Medd (personal communication, 1981) somewhere between Cores 109 and 111, on the basis of the change in nannofossil preservation and assemblage, although a drop in the CCD could be an alternative explanation. Poor recovery (about $5 \%$ ) within this interval precludes recognition of a hiatus or transition. The top of this marl unit (basal part of Core 103?) coincides with a sudden decline in limestone turbidite abundance (= seismic reflector $\mathrm{D}^{\prime}$ ) and a change in microfacies (disappearance of pelagic bivalves) so that a hiatus is suspected.

The "filament facies" of Upper Jurassic sediments recovered at various DSDP sites in the Atlantic has been tentatively correlated with Tethyan pelagic facies having abundant Bositra (= Posidonia) bivalve shells (Jansa et al., 1979). If these Atlantic bivalves are Bositra, which has not yet been demonstrated, then the Toarcian to Oxfordian range of Bositra (Jefferies and Minton, 1965) would place an Oxfordian upper age limit on the "filament facies" of Cores 104 to 106. However, a "filament facies" was also identified in the lowest marl of Site 105, drilled between Magnetic Anomalies M-24 and M-25, hence with a basement age of earliest Kimmeridgian.

Carbonate compensation depth. The aragonite in the reddish marl of Core 104, fine pelagic bivalve shells above Core 108, and an increase in carbonate content from less than $10 \%$ in Cores 114 and 115 to 30 to $35 \%$

Table 5. Microfacies of Kimmeridgian-?Oxfordian marls from Hole 534A.

\begin{tabular}{|c|c|c|c|c|c|c|c|c|}
\hline $\begin{array}{c}\text { Sample } \\
\text { (core-section, } \\
\mathrm{cm} \text { from top of section) }\end{array}$ & Lithology & Bioclasts (\%) & \multicolumn{5}{|c|}{ Silt-sized components $(\%)$} & Comments \\
\hline $104-1,82$ & Gray marl & $\begin{array}{l}\text { Calcified radiolarians } \\
\text { (up to 25), bivalve } \\
\text { "filaments" (up } \\
\text { to 10) }\end{array}$ & 0 & 0 & 0 & 0 & $\begin{array}{l}\text { Microspar } \\
\quad \text { (up to 55) }\end{array}$ & $\begin{array}{l}\text { One horizon of pellets } \\
\text { (15); shells have } \\
\text { prismatic spar } \\
\text { overgrowths. }\end{array}$ \\
\hline $104-4,46$ & Reddish marl & $\begin{array}{l}\text { Bivalve "filaments" } \\
\text { (10), mollusk } \\
\text { fragments (1), cal- } \\
\text { cified radiolarians } \\
\text { (2) }\end{array}$ & 0 & 0 & 1 & 0 & $\begin{array}{l}\text { Microspar } \\
\text { (10) }\end{array}$ & $\begin{array}{l}\text { "Filaments" have } \\
\text { prismatic spar } \\
\text { overgrowths; band } \\
\text { of micrite appears } \\
\text { at bottom. }\end{array}$ \\
\hline $104-4,73$ & Gray marl & $\begin{array}{l}\text { Bivalve "'filaments" } \\
\text { (5); calcispheres } \\
\text { (3) }\end{array}$ & 1 & 0 & 2 & 1 & $\begin{array}{l}\text { Microspar } \\
\text { (7) }\end{array}$ & $\begin{array}{l}\text { "Filaments" have } \\
\text { prismatic spar } \\
\text { overgrowths. }\end{array}$ \\
\hline $108-1,74$ & Reddish marl & & 2 & 0 & 1 & 0 & $\begin{array}{l}\text { Microspar } \\
\text { (40) }\end{array}$ & Possible small pellets. \\
\hline
\end{tabular}


in Cores 112 and 108 strongly suggest that the CCD and the aragonite compensation depth (ACD) were steadily dropping during the deposition of the uppermost variegated claystones and the greenish gray marl.

Assuming an age of late Oxfordian for Core 112, the paleodepth of the sediment surface at the time of intersection with the CCD is about $3300 \mathrm{~m}$. If Core $104 \mathrm{rep}-$ resents the intersection with the aragonite compensation depth, then in the Kimmeridgian, an ACD of about $3300 \mathrm{~m}$ would be implied.

The dissolution of carbonate depends on many factors (Bathurst, 1975; Berger and Winterer, 1974). One is the $\mathrm{pH}$ of the interstitial water in the uppermost sediment. Perhaps the sharp reduction in organic material, hence a rise in $\mathrm{pH}$, between the variegated claystones and the greenish gray marls may be a factor in the increased abundance of carbonate. Another factor could be the periodic rapid burial of the marl by limestone turbidites. However, this does not explain the continued presence of aragonite in the overlying Tithonian red marls, therefore a regional drop in the CCD and ACD levels in preferred.

\section{Red Marl (Tithonian-?Kimmeridgian) \\ Core 92, Section 2, $40 \mathrm{~cm}$ through Core 103 (1342.0-1437.0 m sub-bottom)}

\section{Macroscopic Features}

The Jurassic unit consists of reddish calcareous sediments, which change from grayish red claystone (averaging $15-20 \% \mathrm{CaCO}_{3}$ ) in Cores 103 to 94 (Fig. 17), to pale red marly limestone (averaging $50-70 \% \mathrm{CaCO}_{3}$ ) in Cores 93 to 92 (Fig. 18). Interspersed within this generalized progression are beds of greenish gray claystone and marl (Cores 103-100), black carbonaceous clay (Cores 100-96), and light gray or pink limestone (Cores 97-92). At the top of the unit is a smooth transition to the latest Tithonian and Berriasian white limestone unit.

The 80 to $90 \mathrm{~m}$ of red marls span most of the Tithonian stage, perhaps into the Kimmeridgian, yielding sedimentation rates of between 9 and $13 \mathrm{~m} / \mathrm{m}$.y. Sedimentation rates were probably less in the clay-rich lower portion and greater in the lime-rich higher portion.

The red marl has minor to moderate bioturbation and commonly has vague laminations. Greenish gray mottles are common in some cores, in some cases associated with burrows.

In the clay-rich lower part of the marl unit are thin greenish or bluish gray layers spaced every 10 to $30 \mathrm{~cm}$. These gray layers appear to have the same composition as the adjacent red marl but possibly have a slightly higher organic content.

Black claystones with rare pyrite nodules also occur within this interval and have organic carbon values of 1.3 to $3.1 \%$. Whether these values are the result of episodes of high organic input or are redeposition events could not be determined.

Core 95 had a general 5 to $10 \%$ inclination of lamination, and Core 96 had a short interval with similar inclination. A possible explanation would be current deposition, but in the absence of supporting evidence a drilling artifact is more likely.

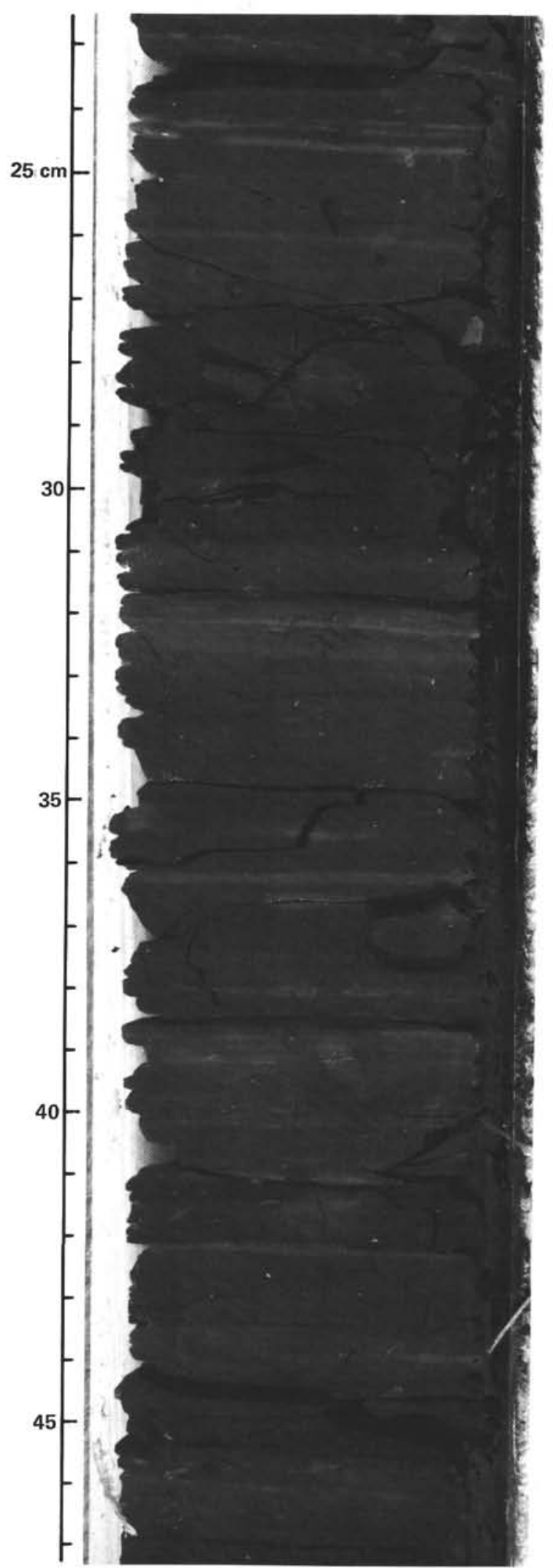

Figure 17. Sample 534A-100-3, 23-47 cm-grayish red claystone typical of lower portion of the Tithonian-?Kimmeridgian red marl unit. (Mottling, greenish gray streaks, and Chondrites burrows are abundant. Olive black, carbonaceous claystone forms the bed at $27-31 \mathrm{~cm}$. This core contained aragonitic shell fragments.) 


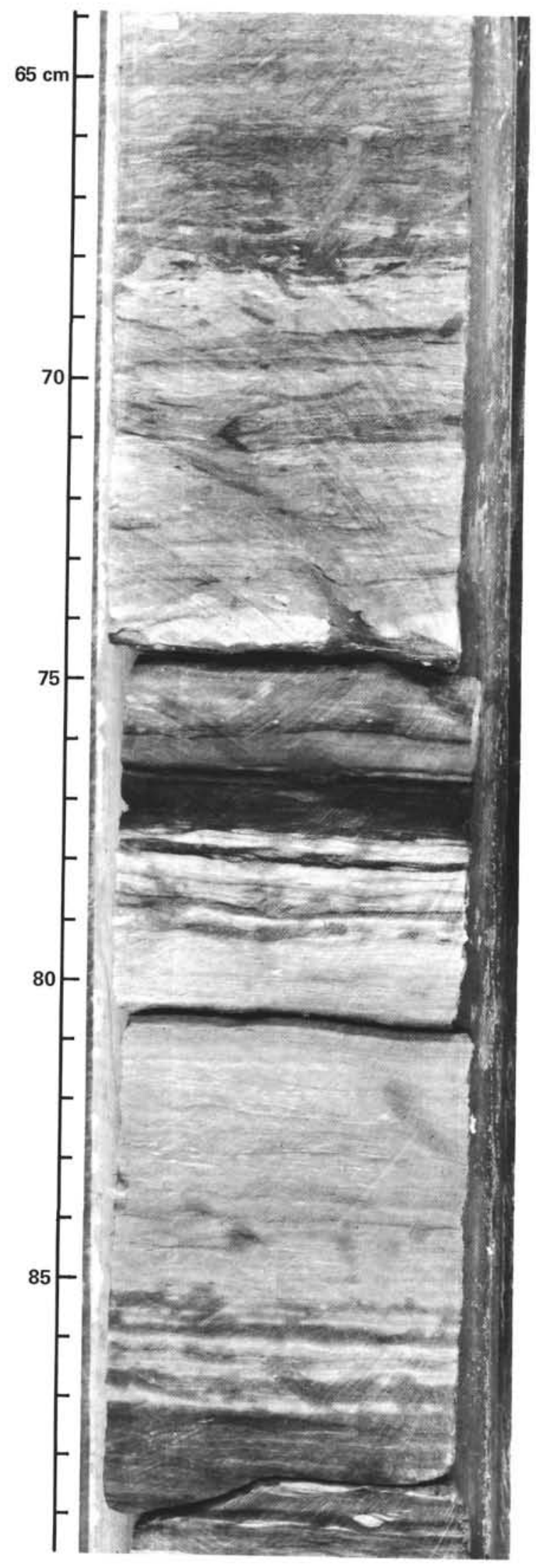

Figure 18. Pale red and light gray marly limestone in the uppermost part of the red marl unit-Sample 534A-92-3, 64-90 cm. (Bioturbation is abundant. The age is Tithonian.)

\section{Microfacies}

The typical red marl is a biomicrite with variable recrystallization to microspar (Table 6). In general, the more lime-rich marl and marly limestone have the greatest abundance of microfossils, especially calcified radiolarians (as much as $20 \%$ of the sediment).

The clay-rich marl in the lower portion of the unit (Cores 103-99) contains 4 to $10 \%$ bioclasts, mainly in the form of unidentified silt-sized debris and minor amounts of calcispheres, radiolarians, and Saccocoma (Fig. 19). Terrigeneous silt is about 2 to $3 \%$. Laminated horizons are seen as small variations in clay content in this section. Small lenticular concentrations of terrigenous silt and calcispheres may be caused by current winnowing.

The lime-rich marl of the upper portion of the unit has 10 to $25 \%$ bioclasts (Fig. 20). The abundant radiolarians are generally oval (partially flattened) and filled and/or replaced by microspar or spar; pyrite replacement of skeletal fragments is very rare. Siliceous nodules were observed in some of these lime-rich cores, the silica probably derived from the dissolution of radiolarian tests. Calpionellids occur above Core 95 and are commonly filled by calcite spar. Calcispheres and shell fragments are minor constituents, and terrestrial silt is very rare. The micrite is commonly 20 to $30 \%$ recystallized to microspar.

Smear slides of the red marls in Cores 99 and 100 have abundant (10-35\%), fine, silt-sized needles identified as aragonite. An ammonite and numerous macroscopic shell fragments (of ammonites?), which retained a pearly luster, were noted in Core 100. Aragonite was identified by X-ray diffraction in Cores 100 and 95 (see Site 534 report).

\section{Chemistry and Mineralogy}

The dominant clay mineral is smectite $(85 \%)$, with minor amounts of illite $(10 \%)$ and chlorite $(5 \%)$, and traces of mixed-layer clays (Chamley et al., this volume). These proportions of clay minerals remain fairly constant through the red marl unit.

Major and minor element analyses and interpretations have been made on the identical unit at Site 391 only $22 \mathrm{~km}$ to the southwest (Murdmaa, 1978; Murdmaa et al., 1978). Their results are briefly summarized as follows.

First, the red color is caused by hematite. Iron composes about $4 \%$ of the bulk sediment by weight, and is about $6 \%$ on a carbonate-free basis. This proportion remains the same in the overlying Lower Cretaceous white and gray limestones and marls. $\mathrm{Fe}^{+2}$ is only about 5 to $15 \%$ of the total iron in the Tithonian red marls, as contrasted to 25 to $50 \%$ in the Lower Cretaceous gray limestones. Manganese is usually 0.02 to $0.07 \%$ on a carbonate-free basis.

Second, aluminum is normally 5 to $8 \%$. The $(\mathrm{Fe}+$ $\mathrm{Mn}$ )/Al ratio is typically 0.60 to 0.75 , which isn't significantly higher than the average hemipelagic sediment or the 0.57 mean ratio of the Lower Cretaceous gray limestone and marls (Robertson and Bliefnick, this 
Table 6. Microfacies of Hole 534A Tithonian red marls.

\begin{tabular}{|c|c|c|c|c|}
\hline $\begin{array}{c}\text { Sample } \\
\text { (core-section } \\
\mathrm{cm} \text { from top of section) }\end{array}$ & Lithology & Bioclasts $(\%)$ & $\begin{array}{l}\text { Silt-sized } \\
\text { components } \\
(\%)\end{array}$ & Comments \\
\hline $92-2,71$ & Red limestone & $\begin{array}{l}\text { Calpionellids (5), calcispheres (3), } \\
\text { calcified radiolarians (3) }\end{array}$ & Phosphate (1) & $\begin{array}{l}\text { Microspar }(30 \%) \text {, less in } \\
\text { burrow. }\end{array}$ \\
\hline $92-4,92$ & Red marl & $\begin{array}{l}\text { Calcified radiolarians (5), } \\
\text { (?)calpionellids (2) }\end{array}$ & & $\begin{array}{l}\text { White limestone patches have } \\
\text { pelletal micrite with } 10 \% \\
\text { calcified radiolarians. }\end{array}$ \\
\hline $92-6,51$ & Red marl & $\begin{array}{l}\text { Calcified radiolarians }(7-15), \\
\text { calpionellids }(2)\end{array}$ & Phosphate (1) & $\begin{array}{l}\text { Radiolarians are partially } \\
\text { flattened; microspar (5\%). }\end{array}$ \\
\hline $93-3,43$ & Pink limestone & $\begin{array}{l}\text { Calcified radiolarians (1), calpio- } \\
\text { nellids (1-2), calcispheres } \\
(1-2)\end{array}$ & $\begin{array}{l}\text { Quartz (1), } \\
\text { opaques (2) }\end{array}$ & $\begin{array}{l}\text { Microspar (15\%); one ostra- } \\
\text { code(?) that is } 0.3 \mathrm{~mm} \\
\text { long and calcite-filled. }\end{array}$ \\
\hline $93-4,43$ & $\begin{array}{l}\text { Pink limestone } \\
\text { and marl }\end{array}$ & $\begin{array}{l}\text { Calcified radiolarians (8), calpio- } \\
\text { nellids (2), calcispheres (1), } \\
\text { shell fragments (2) }\end{array}$ & $\begin{array}{l}\text { Phosphate (2), } \\
\text { opaques (1) }\end{array}$ & Microspar $(30 \%)$ \\
\hline $94-1,20$ & $\begin{array}{l}\text { Red marls and } \\
\text { pink limestone }\end{array}$ & $\begin{array}{l}\text { Calcified radiolarians (2-5), cal- } \\
\text { cispheres (2), calpionellids (1), } \\
\text { (?)Saccocoma (rare), shell } \\
\text { fragments (3) }\end{array}$ & Phosphate (I) & $\begin{array}{l}\text { Microspar }(20 \%) \text {; pellets } \\
(2 \%) ; \text { radiolarians are par- } \\
\text { tially flattened. }\end{array}$ \\
\hline $94-4,74$ & $\begin{array}{l}\text { Red marl and } \\
\text { white limestone }\end{array}$ & $\begin{array}{l}\text { Calcified radiolarians (15), calci- } \\
\text { spheres (1), calpionellids } \\
\text { (rare) }\end{array}$ & & $\begin{array}{l}\text { Radiolarians (up to } 15 \% \text { of } \\
\text { some horizons) are par- } \\
\text { tially flattened. }\end{array}$ \\
\hline $95-3,2$ & $\begin{array}{l}\text { Red limestone and } \\
\text { marl }\end{array}$ & $\begin{array}{l}\text { Shell fragments (2), calcispheres } \\
\text { (rare) }\end{array}$ & $\begin{array}{l}\text { Mica }(5) \\
\text { quartz (2), } \\
\text { opaques (4) }\end{array}$ & $\begin{array}{l}\text { Micrite with oriented mica } \\
\text { and clay. }\end{array}$ \\
\hline $95-3,81$ & White limestone & $\begin{array}{l}\text { Calcified radiolarians (20), Calci- } \\
\text { fied calpionellids (2), calci- } \\
\text { spheres (2), shell fragments } \\
\text { (1), (?)Saccocoma (2) }\end{array}$ & & $\begin{array}{l}\text { Microspar }(25 \%) \text {; radiolarians } \\
\text { are partially flattened; } \\
\text { some dolomite replace- } \\
\text { ment; highly recrystallized. }\end{array}$ \\
\hline $96-5,36$ & Red Marl & $\begin{array}{l}\text { Calcified radiolarians (20), Shell } \\
\text { fragments (3), calcispheres } \\
\text { (rare) }\end{array}$ & $\begin{array}{l}\text { Phosphate (1), } \\
\text { opaques (2) }\end{array}$ & $\begin{array}{l}\text { Many "ghosts" of former } \\
\text { bioclasts, now microspar. }\end{array}$ \\
\hline $99-1,32$ & Brown marl & $\begin{array}{l}\text { Calcified radiolarians (3), calci- } \\
\text { spheres (1), large bivalve } \\
\text { shell fragment }\end{array}$ & $\begin{array}{l}\text { Quartz (1), } \\
\text { opaques (1), } \\
\text { phosphate (1) }\end{array}$ & $\begin{array}{l}\text { Laminations caused by vari- } \\
\text { able clay content; radio- } \\
\text { larians are flattened. }\end{array}$ \\
\hline $99-2,46$ & $\begin{array}{l}\text { Reddish brown } \\
\text { marl }\end{array}$ & $\begin{array}{l}\text { Unidentifiable debris (10), Calci- } \\
\text { fied radiolarians (1), calci- } \\
\text { fied (1), calcispheres (rare) }\end{array}$ & $\begin{array}{l}\text { Phosophate (2), } \\
\text { mica }(2-3) \\
\text { quartz (2), } \\
\text { opaques (4) }\end{array}$ & $\begin{array}{l}\text { Silt-sized particles in dense } \\
\text { micrite. }\end{array}$ \\
\hline $100-2,17$ & Gray marl & $\begin{array}{l}\text { Unidentified debris (10), Sacco- } \\
\text { coma (rare), calcispheres (1), } \\
\text { (?)gastropod (one) }\end{array}$ & $\begin{array}{l}\text { Mica (2), } \\
\text { quartz (1), } \\
\text { opaque (2) }\end{array}$ & $\begin{array}{l}\text { Rounded patches of micro- } \\
\text { spar }(5 \%) \text { could be filled } \\
\text { radiolarians. }\end{array}$ \\
\hline $101-1,7$ & Red marl & $\begin{array}{l}\text { Calcispheres (2), shell fragments } \\
\text { (rare) }\end{array}$ & $\begin{array}{l}\text { Quartz (1), } \\
\text { mica (1), } \\
\text { opaques (3), } \\
\text { calcite (2) }\end{array}$ & $\begin{array}{l}\text { Rare micrite pellets with pos- } \\
\text { sible shape of foramini- } \\
\text { fers; lenses (1-2 mm) are } \\
\text { rich in quartz and calci- } \\
\text { spheres. }\end{array}$ \\
\hline $103-1,7$ & Grayish red marl & $\begin{array}{l}\text { Shell fragments (2), unidentifi- } \\
\text { able debris (2) }\end{array}$ & & $\begin{array}{l}\text { Burrows filled with micro- } \\
\text { spar, one has geopetal } \\
\text { fabric; some micrite clus- } \\
\text { ters may be micritized bio- } \\
\text { clasts. }\end{array}$ \\
\hline
\end{tabular}

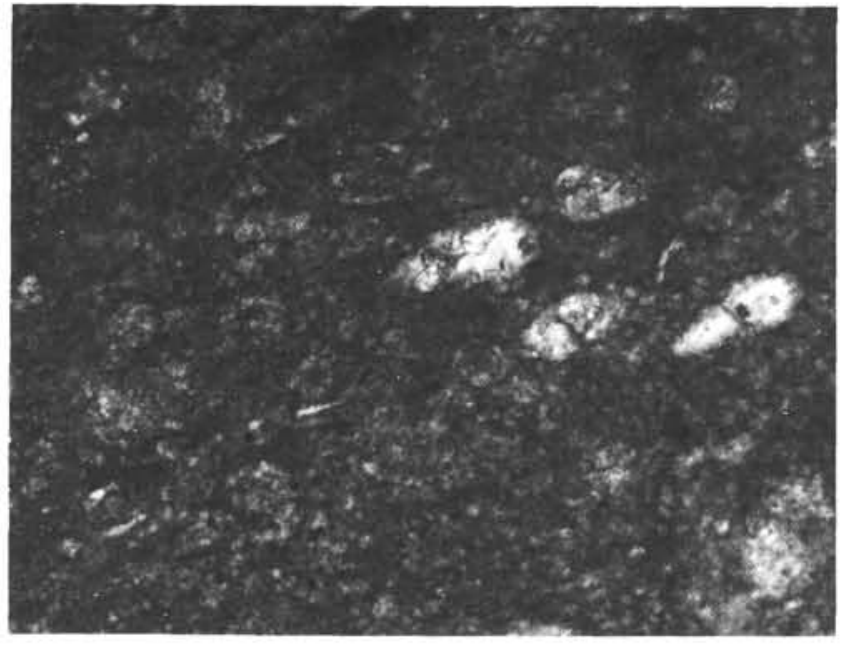

Figure 19. Photomicrograph of thin section (Sample 534A-95-5, 36 $\mathrm{cm}$ ) in the lower portion of the red marl unit. (Radiolarians are filled with sparry calcite and the oval-shaped one in the lower left is about $150 \mu \mathrm{m}$ in length. The marl matrix is micrite with partial microspar recrystallization. The age is Tithonian.)

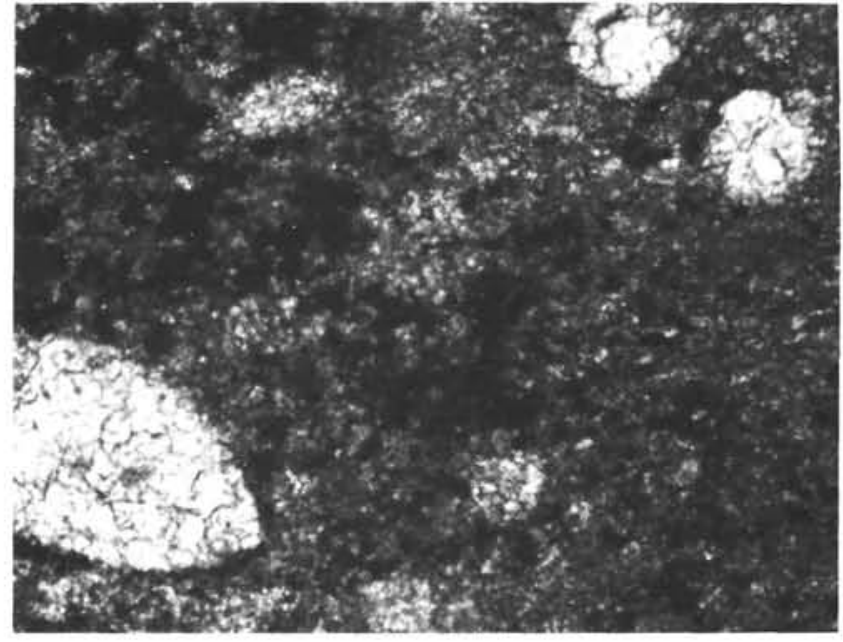

Figure 20. Photomicrograph of thin section (Sample 534A-93-4, 43 $\mathrm{cm}$ ) in the upper portion of the red marl unit. (Oval-shaped radiolarians filled by sparry calcite are common. Other bioclasts include calcispheres [just below center] and calpionellids [one is at bottom left]. The micrite matrix is partially micritized; the age is late Tithonian; the scale is $420 \mu \mathrm{m}$ in width.) 
volume). The $\mathrm{Al} / \mathrm{Ti}$ ratio has a mean of about $20 . \mathrm{SiO}_{2}$ is $41 \%$ by weight. The $\mathrm{SiO}_{2} / \mathrm{Al}_{2} \mathrm{O}_{3}$ ratio of 4.0 to 4.7 is slightly high, and it was suggested that some authigenic silicification may be present. $\mathrm{MgO}$ is $3.3 \%$ and $\mathrm{K}_{2} \mathrm{O}$ is $2 \%$.

Third, trace elements are low in concentration: The mean value of the $\mathrm{Cu}$ content is $80 \mathrm{ppm}$ (on a carbonatefree basis); $\mathrm{Zn}, 100 \mathrm{ppm}$; Ni, $145 \mathrm{ppm}$; Co, $40 \mathrm{ppm}$; and $\mathrm{Cr}$, about $100 \mathrm{ppm}$. Values are typical or low for hemipelagic and pelagic sediments of the western North Atlantic.

Finally, the chemistry and mineralogy of the noncarbonate fraction of the red marl unit was interpreted by Murdmaa to indicate a terrigenous origin without the significant input of metalliferous exhalations from active ridges, which had been suggested by Lancelot et al. (1972, p. 922) to explain the red color.

\section{Discussion and Interpretation}

Red marl to white limestone transition. At the end of the Jurassic, there was a widespread transition in the pelagic sediments of the Atlantic-Western Tethys from red, clay-rich marls to white limestones. In Parts Three and Four of this paper, we explore the regional significance of and oceanographic changes responsible for this dramatic change; we therefore restrict ourselves here to the nature of the color change documented so clearly in the relatively expanded record of Site 534 and nearby Site 391.

At Site 534, the color transition from reddish hues to light gray and greenish blues spans the lower portion of Core 92 and upper portion of Core 93 , or about $10 \mathrm{~m}$. The transition from dominantly (over $70 \%$ ) marl to limestone spans about $20 \mathrm{~m}$ (most of Cores 92, 93, and 94). The associated impedance contrast produces the seismic reflector C (Sheridan et al., this volume). The gradual increase in $\mathrm{CaCO}_{3}$ content begins earlier, in about Core 99.

Across this transition, total $\mathrm{Fe}$ decreases from an average of $4.7 \%$ in the red marls to $1.1 \%$ in the white limestones (from Murdmaa et al., 1978). However, the simultaneous decrease in clay content from about $80 \%$ to $15 \%$ implies that total $\mathrm{Fe}$, when calculated on a carbonate-free basis, changes insignificantly (average of $6.0 \%$ to $5.4 \%$ ). As a result, the $\mathrm{Fe} / \mathrm{Al}$ ratio remains a constant 0.6 to 0.7 . When normalized to clay content, iron input remains constant across the red marl to the light gray limestone transition.

The net sedimentation rate of the red marl unit is between 9 and $13 \mathrm{~m} / \mathrm{m} . y$. , therefore the sedimentation rate of clay is about 3 to $7 \mathrm{~m} / \mathrm{m}$.y. The net sedimentation rate of the overlying white limestone is 25 to $30 \mathrm{~m} /$ m.y. (110-120 m; the estimated duration of the Berriasian is $4 \mathrm{~m}$.y. [Van Hinte, 1976]). With a mean clay content of $17 \%$ (the average of 27 analyses of carbonate content in Cores $82-91$ is $83 \%$ ), the sedimentation rate of clay is about $5 \mathrm{~m} / \mathrm{m}$.y. This procedure assumes that the sediments are only carbonate and clay. Actually there is also 1 to $2 \%$ terrestrial silt, about $1 \%$ organics, and traces of phosphate and chert; but these are insignificant when compared to the clay contents. From these estimates, it appears that no reduction in clay input per unit time occurs across the marl to limestone transition. The major change must be the input of carbonate (a rise from $3.5-5 \mathrm{~m} / \mathrm{m}$.y. to nearly $15 \mathrm{~m} / \mathrm{m}$.y.). The organic carbon content remains a constant 0.1 to $0.2 \%$.

Free iron is normally delivered to the seafloor in the form of ferric hydroxides, ferromagnesian minerals, particulate oxides, or $\mathrm{Fe}$-rich clays. Finely divided $\mathrm{Fe}$ hydroxide (goethite) is unstable with respect to hematite plus water under most natural conditions (Berner, 1969). Authigenic hematite was observed in the red marl unit at nearby Site 391 (Murdmaa, 1978).

In this unit at Site 534 hematite imparts the magnetic fabric. Alignment in the Earth's magnetic field must have taken place early in diagenesis, probably at or near the sediment surface (Ogg, this volume). The overlying white limestone has a magnetite carrier of magnetic remanence.

Two factors may influence the observed change from hematite dominance in the red marl to pyrite and magnetite in the overlying white and gray limestone. First, the ratio of total $\mathrm{Fe}$ to organic carbon is much higher in the red claystones, implying more oxygenated conditions during diagenesis. Under these conditions, formation of the higher-oxidation-state hematite is favored. Second, with the increased sedimentation rate of the limestone, the reactive iron was buried faster and isolated from interchange with oxygenated seawater during early diagenesis. Thus low net sedimentation rates under relatively oxidizing conditions favor hematite, whereas higher organic content and faster burial favor magnetite and pyrite.

In summary, the red to white-gray change is caused by the increased influx of carbonate and, to a lesser degree, of organic matter.

Carbonate compensation depths. Aragonite was identified by X-ray diffraction in the marls of Cores 104, 100 , and 95 , observed as microscopic needles in smear slides of red marls in Cores 100 and 99 , and was present as ammonite and other shell fragments retaining an original pearly luster in Core 100 . This last feature was also noted at the same interval at nearby Site 391.6 Hence, the seafloor in this region was above the aragonite compensation depth (ACD) during this period (part of the Kimmeridgian and the early Tithonian).

Seismic stratigraphy shows that the earlier lime-rich turbidite episodes had formed a level seafloor from the Blake Plateau to Site 534 and beyond. The sediment surface at Site 534 during the Tithonian was probably as deep as any part of the Atlantic. Thus this entire Atlantic region was "above" the CCD and ACD.

No aragonite occurs above Core 95 , so the ACD was approximately $3700 \mathrm{~m}$ at the time of the deposition of Core 95 (middle Tithonian). This coincides with the early stages of increasing carbonate influx.

The seafloor remained "above" the CCD through the Tithonian and much of the Early Cretaceous. How-

\footnotetext{
${ }^{6}$ Bourbon (1978) suggested that the ammonites in the red marl at Site 391 may have been transported from shallower depths even though no redeposition features were observed.
} 
ever, the scanty presence of poorly preserved foraminifers is cited as evidence that the seafloor was near the dissolution level (see the Site 534 report), therefore suggesting that a CCD was developing in the Atlantic when carbonate deposition increased in the late Tithonian.

Microfauna. Radiolarians, always calcite-filled or replaced, are the main microfauna in the upper portion of the red marl unit but are rare in the lower portion. This is possibly the result of increased preservation similar to that within the white and gray limestone of the overlying Blake-Bahama Formation (Robertson and Bliefnick, this volume). More rapid carbonate deposition buried the radiolarian tests before they dissolved at or just below the sediment surface. Subsurface alkaline conditions would then have favored dissolution and replacement of silica by sparry calcite. Also, the influx of radiolarians may have been greater, reflecting the increased productivity in the surface waters.

Saccocoma, a pelagic crinoid that leaves abundant sand-sized fragments in Tethyan limestones of the Kimmeridgian and early Tithonian, is virtually absent at Sites 534 and 391. Site 105 to the north and Sites 99 and 100 to the south have a "Saccocoma microfacies"' (Jansa et al., 1979). Bourbon (1978) suggested two possible solutions to this anomaly: (1) deposition was below the CCD and the aragonite bioclasts are a fluke of transport and rapid burial or (2) Saccocoma are absent for an unknown reason.

Some other alternatives to explain the lack of Saccocoma at Sites 534 and 391 are: (1) There is a hiatus including the early Tithonian and part of the Kimmeridgian. Biostratigraphic control is not adequate to resolve such a hiatus, as there are no characteristic early Tithonian fauna. The red marl would have a much higher sedimentation rate, which was interrupted for an extended period in the middle of the unit. This hypothesis seems unlikely and is inconsistent with the magnetostratigraphy. (2) Saccocoma fragments became unrecognizable during diagenesis. Many bioclasts are replaced by micrite and microspar to produce unidentifiable "ghost" shapes in thin sections. However, diagenesis normally produces overgrowths on crinoid fragments rather than replacement. (3) Saccocoma were not locally abundant. Perhaps the level of nutrients was inadequate in this region to support Saccocoma. When the late Tithonian explosion in productivity began, Saccocoma were extinct. The occurrence of a Saccocoma facies at Site 100 (south of Site 534) may be related to its location near the seaward edge of the Bahama Banks and the abundance of "pelagic turbidites" (Lancelot et al., 1972).

\section{Lime-Rich Turbidite Units}

\section{Bioclastic Pelmicrite Turbidites (Oxfordian-late Callovian) \\ Core 115 to Core 125, Section 4, $20 \mathrm{~cm}$ (1531.5-1617.2 m sub-bottom)}

\section{Macroscopic Features}

This turbidite sequence of olive gray limestones begins a.s a minor constituent in Core 125, quickly in- creases in abundance to become the dominant lithology in Cores 124 to 117 , then rapidly diminishes in importance in Cores 116 and 115. At the limits of the unit the beds are thin $(3-10 \mathrm{~cm})$, dark greenish gray, and relatively clay-rich. The majority of the beds in the main part of the unit are light olive gray and 10 to $45 \mathrm{~cm}$ thick. Sedimentary features include graded bedding, laminations, convolute laminations, intraclasts of claystone, and bioturbation with Chondrites burrows in the upper portions (Fig. 21). The lower and upper contacts of the lime-rich turbidites with the host claystones are sharp, and the claystone typically fills the Chondrites burrows.

\section{Microfacies and Chemistry}

The turbidites are generally graded. The basal portions are bioclastic pelmicrite with 10 to $30 \%$ bioclasts and 30 to $40 \%$ micrite pellets (see Table 7) (Fig. 22). The upper portions have only sparse bioclasts and poorly defined pellets in a micrite matrix. At the top, there is a rise in the clay and amorphous clay-sized organic contents. Terrestrial silt (quartz, mica, etc.) rarely exceeds $5 \%$.

The bioclasts are predominantly radiolarians in the upper portion of the unit and predominantly fine bivalve "ffilaments" in the lower portion. The radiolarians are normally filled and replaced by calcite microspar and spar, but in many cases they are replaced by pyrite, and in one bed (Sample 534A-120-1, $48 \mathrm{~cm}$ ) they are silicified. Other less common bioclasts include echinoderm debris, shell fragments, and rare benthic foraminifers and calcispheres.

The carbonate content is 80 to $90 \%$ through the bulk of the unit ( 8 analyses). One darker, more marly bed has $64 \% \mathrm{CaCO}_{3}$. Organic carbon is low $(0.1-0.3 \%)$.

Major element chemistry was analyzed for three beds (see Table 2) (previously discussed with the lower claystone unit).

\section{Discussion and Interpretation}

The abrupt decrease in the abundance of the limestone turbidites between Cores 117 and 116 creates a sudden change in bulk physical properties of the sediment. This contrast has been correlated with the regional seismic reflector D (see Sheridan et al., this volume).

The microfacies of these turbidites imply a source region well above the CCD, but without shallow-water material. Using the classification of Wilson (1975), this "microbioclastic calcisiltite" is typical of lower slope or basinal environments. This does not preclude a setting before redeposition of a restricted marine shoal or shelf lagoon where pelletal mudstones are common (Bathurst, 1975), but other shallow-water material would be expected to be incorporated during redeposition.

Seismic reflector D (or the top of seismic interval WNA-9 of Shipley et al., 1978) is seen as a basement topography-levelling feature that extends eastward from the base of the Blake Spur Ridge, breaches that barrier in low places, and pinches out a short distance east of Site 534. We therefore infer the source of these pelletal turbidites to be the Blake Plateau, which implies that 


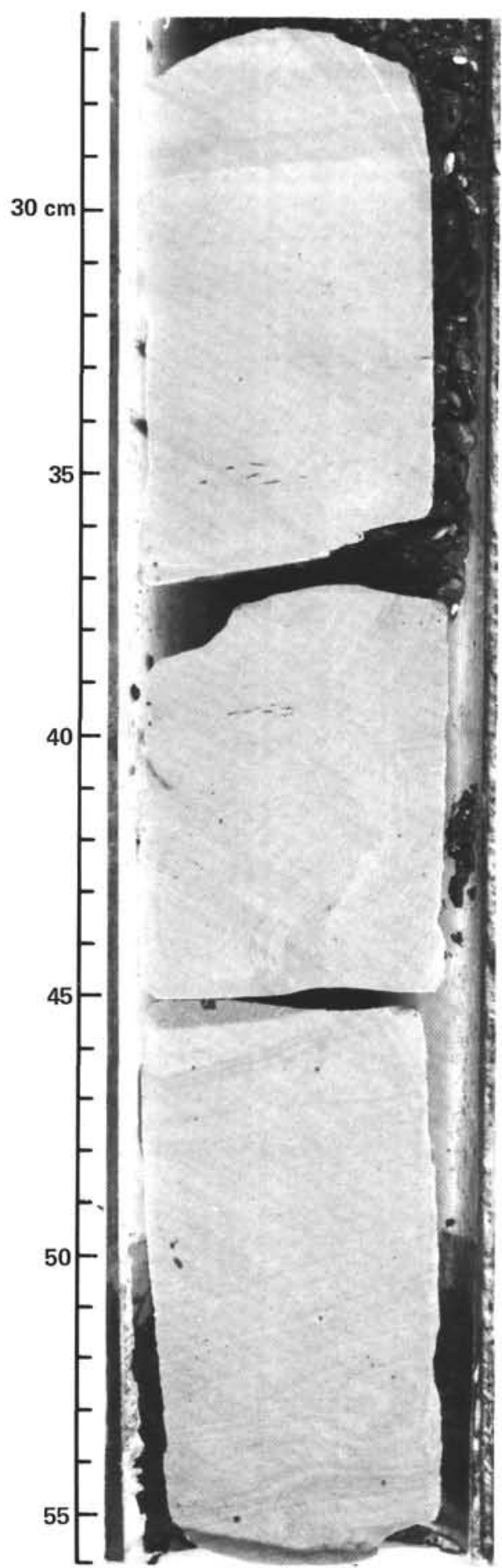

Figure 21. Turbidite beds of bioclastic pelmicrite limestone of the Oxfordian-late Callovian turbidite interval-Sample 534A-117-1, 26$56 \mathrm{~cm}$. (Sedimentary structures include convolute laminations, grading, and Chondrites burrows in upper portions. The age is Oxfordian.)

the turbidites originated about $150 \mathrm{~km}$ to the west. Thus we believe that the Blake Plateau was an active carbonate shelf during the early Oxfordian-late Callovian. Pelletal turbidite activity may have begun much earlier (the seismic interval below reflector D reaches $1000 \mathrm{~m}$ in thickness west of the Blake Spur Ridge), but it did not breach the Blake Spur basement high and fill the topographic lows to the level of Site 534 until the late Callovian. Activity appears to have decreased sharply in the middle Oxfordian.

\section{Micrite Turbidites (?Tithonian-Oxfordian) Cores 100 through 114 (1401.0-1531.5 m sub-bottom)}

\section{Macroscopic Features}

Sporadically throughout the $130-\mathrm{m}$ interval of Cores 114 through 100 are light gray to dark greenish gray, fine-grained limestone beds. These beds are typically 5 to $10 \mathrm{~cm}$ thick, but can range from 3 to $20 \mathrm{~cm}$. The homogeneous micrite displays few sedimentary features; however, their turbidite origin can be inferred from the sharp contacts, unique lithology, and bioturbation in the upper portions.

\section{Microfacies and Chemistry}

The turbidite beds are composed of nearly pure micrite (Table 8). Bioclasts, where present, are less than $3 \%$ of the total volume. The few bioclasts include shell fragments and rare calcified radiolarians and calcispheres. Other silt-sized particles of organics, pyrite, quartz, and mica are rare, except in one bed in Core 113 where they are an unusual $15 \%$ of the sediment.

The carbonate content averages $90 \%$, with a range of 84 to $90 \%$ ( 3 analyses). Organic carbon is 0.1 to $0.2 \%$.

\section{Discussion and Interpretation}

The micrite turbidites span most of the Oxfordian and Kimmeridgian and terminate early in the Tithonian red marl unit. The source region of the pelagic lime mud was well above the CCD, but deep; probably the Blake Plateau lower slope. These distal turbidite facies may be a fine-grained continuation of the underlying bioclastic pelmicrite turbidite episode of the late Callovian-early Oxfordian. Their regional extent cannot be determined, as they are not associated with a seismic reflection interval. However, limestone beds in the Kimmeridgian basal greenish gray marls of Site 105 are also probably a distal turbidite facies (Bernoulli, 1972). This suggests that the lower contintental slopes shed fine-grained limestone turbidites extensively onto the ocean floor.

\section{Bioclastic Pelletal Microsparite Turbidites (Kimmeridgian-?Oxfordian) \\ Cores 104 through 110 (1437.0-1495.5 m sub-bottom)}

\section{Macroscopic Features}

Turbidites of medium- to coarse-grained limestone compose nearly half of the sediment within this interval. Colors range from light gray to yellowish gray to greenish gray. The beds have typical turbidite features including graded bedding, flute casts and eroded bases, convolute to parallel lamination, claystone intraclasts, current cross-bedding, and bioturbated upper portions (Fig. 23). Thickness ranges up to $50 \mathrm{~cm}$, and frequency 
Table 7. Microfacies of Hole 534A lime-rich turbidites (Oxfordian-late Callovian).

\begin{tabular}{|c|c|c|c|c|}
\hline $\begin{array}{c}\text { Sample } \\
\text { (core-section, } \\
\text { cm from top of section) }\end{array}$ & Lithology & Bioclasts (\%) & $\begin{array}{l}\text { Silt-sized } \\
\text { components }(\%)\end{array}$ & Comments \\
\hline $115-1,12$ & $\begin{array}{l}\text { Marly pelmicrite } \\
\text { limestone }\end{array}$ & $\begin{array}{l}\text { Calcified radiolarians (rare), } \\
\text { shell fragments (rare) }\end{array}$ & $\begin{array}{l}\text { Quartz (6), mica (3), } \\
\text { pyrite, opaques } \\
\text { (tr) }\end{array}$ & Micrite has a pelletoid texture. \\
\hline $115-1,17$ & Marly micrite & None & $\begin{array}{l}\text { Quartz (5), clastic } \\
\text { calcite (5), mica } \\
\text { (3), opaques (2), } \\
\text { phosphate (rare) }\end{array}$ & $\begin{array}{l}\text { Calcite is } 20-30 \mu \mathrm{m} \text {, with no } \\
\text { identifiable biogenic origin; } \\
\text { Chondrites burrows are } \\
\text { filled by clay. }\end{array}$ \\
\hline $116-1,70$ & $\begin{array}{l}\text { Radiolarian bio- } \\
\text { micrite }\end{array}$ & Calcified radiolarians (30) & Opaques $(1-2)$ & $\begin{array}{l}\text { Radiolarians are spar or mi- } \\
\text { crospar filled; no pyrite. }\end{array}$ \\
\hline $118-1,19$ & Biomicrite & $\begin{array}{l}\text { Calcified radiolarians (7), } \\
\text { echinoderm plates (3), } \\
\text { shell fragments (2) }\end{array}$ & $\begin{array}{l}\text { Pyrite, phosphate } \\
\text { (rare) }\end{array}$ & $\begin{array}{l}\text { Micrite has a pelletoid or } \\
\text { clotted texture. }\end{array}$ \\
\hline $118-1,29$ & $\begin{array}{l}\text { Laminated pel- } \\
\text { micrite }\end{array}$ & $\begin{array}{l}\text { Echinoderm plates (4), shell } \\
\text { fragments (2), benthic } \\
\text { foraminifers (rare) }\end{array}$ & Phosphate (rare) & $\begin{array}{l}\text { Pelletoid texture; laminae are } \\
\text { more porous, with inter- } \\
\text { locking grains of calcite. }\end{array}$ \\
\hline $118-1,83$ & $\begin{array}{l}\text { Sparse biomi- } \\
\text { crite }\end{array}$ & $\begin{array}{l}\text { Calcified radiolarians (6), } \\
\text { shell fragments (rare) }\end{array}$ & Quartz, mica (rare) & Dense micrite; bioturbated. \\
\hline $120-1,44$ & Marly micrite & None & $\begin{array}{l}\text { Clastic calcite (2), } \\
\text { organics (4), } \\
\text { quartz, phos- } \\
\text { phate, and pyrite } \\
\text { (rare) }\end{array}$ & $\begin{array}{l}\text { Top of turbidite; clay and } \\
\text { amorphous organics in- } \\
\text { crease toward top. }\end{array}$ \\
\hline $120-1,48$ & $\begin{array}{l}\text { Bioclastic pel- } \\
\text { micrite }\end{array}$ & $\begin{array}{l}\text { Silicified radiolarians (17), } \\
\text { shell fragments (9), echi- } \\
\text { noderm plates (2) }\end{array}$ & Pyrite (rare) & $\begin{array}{l}\text { Well-sorted mix of micrite pel- } \\
\text { ets, quartz-replaced radio- } \\
\text { larians, and shell "fila- } \\
\text { ments," coarse-grained } \\
\text { base of turbidite. }\end{array}$ \\
\hline $121-1,6$ & Marly micrite & None & $\begin{array}{l}\text { Quartz (2), mica (3), } \\
\text { opaques ( } 3 \text { ) }\end{array}$ & $\begin{array}{l}\text { Top of turbidite; Chondrites } \\
\text { burrows are clay-rich; there }\end{array}$ \\
\hline 191 06 & & & & $\begin{array}{l}\text { is a sharp upper contact } \\
\text { with claystone. }\end{array}$ \\
\hline $121-1,26$ & $\begin{array}{l}\text { Radiolarian bio- } \\
\text { micrite }\end{array}$ & $\begin{array}{l}\text { Pyrite-replaced radiolarians } \\
\text { (11), Calcified radiolari- } \\
\text { ans (6), shell fragments } \\
\text { (3) }\end{array}$ & $\begin{array}{l}\text { Pyrite, phosphate } \\
\text { (rare) }\end{array}$ & $\begin{array}{l}\text { Middle of a thick }(45+\mathrm{cm}) \\
\text { turbidite. }\end{array}$ \\
\hline $122-1,2$ & $\begin{array}{l}\text { Pelmicrite and } \\
\text { bioclastic } \\
\text { pelletal } \\
\text { microsparite }\end{array}$ & $\begin{array}{l}\text { Radiolaria, calcified (up to } \\
7 \text { ), shell "filaments" (1), } \\
\text { benthic foraminifers (1), } \\
\text { calcispheres (rare) }\end{array}$ & $\begin{array}{l}\text { Quartz (up to 6), } \\
\text { pyrite, phosphate } \\
\text { (1), pellets (30- } \\
50 \mu \mathrm{m})(35)\end{array}$ & $\begin{array}{l}\text { Base of turbidite; concentra- } \\
\text { tion of bioclasts in micro- } \\
\text { spar at base; lamination is } \\
\text { caused by variable pellet } \\
\text { density-size. }\end{array}$ \\
\hline $122-1,67$ & $\begin{array}{l}\text { Marly bioclas- } \\
\text { tic pelmicrite }\end{array}$ & $\begin{array}{l}\text { Fine shell fragments (8), } \\
\text { pyritized radiolarians } \\
\text { (2), echinoderm debris, } \\
\text { calcispheres (1) }\end{array}$ & Quartz (rare) & $\begin{array}{l}\text { Middle of turbidite; pelletoid } \\
\text { texture. }\end{array}$ \\
\hline $122-2,41$ & Marly micrite & None & $\begin{array}{l}\text { Organics (6), quartz } \\
\text { (4), mica (2), } \\
\text { clastic calcite (2), }\end{array}$ & $\begin{array}{l}\text { Top of turbidite; becomes very } \\
\text { clay-rich towards top. }\end{array}$ \\
\hline $122-2,50$ & $\begin{array}{l}\text { Marly bio- } \\
\text { micrite }\end{array}$ & $\begin{array}{l}\text { Shell "filaments" (6), calci- } \\
\text { fied radiolarians (1), } \\
\text { calcified ostracode (one) }\end{array}$ & Pyrite (4) & Vaguely pelletal texture. \\
\hline $123-4,25$ & $\begin{array}{l}\text { Bioclastic pel- } \\
\text { micrite }\end{array}$ & $\begin{array}{l}\text { Shell "filaments" (5), echi- } \\
\text { noderm debris (2), } \\
\text { Pyrite-replaced, calcite- } \\
\text { filled radiolarians (2), } \\
\text { foraminifers, calci- } \\
\text { spheres (rare) }\end{array}$ & $\begin{array}{l}\text { Quartz (1), phos- } \\
\text { phate (1), pyrite } \\
\text { (1) }\end{array}$ & $\begin{array}{l}\text { Base of turbidite; } 30 \% \text { micrite } \\
\text { pellets; matrix is microspar } \\
\text { in places. }\end{array}$ \\
\hline $124-1,10$ & $\begin{array}{l}\text { Bioclastic pel- } \\
\text { micrite }\end{array}$ & $\begin{array}{l}\text { Shell "filaments" (10) } \\
\text { pyritized radiolarians (1) }\end{array}$ & $\begin{array}{l}\text { Quartz (2), phos- } \\
\text { phate (rare) }\end{array}$ & $\begin{array}{l}\text { Base of turbidite; } 40 \% \text { micrite } \\
\text { pellets; rare clay seams. }\end{array}$ \\
\hline $125-1,46$ & Micrite & None & $\begin{array}{l}\text { Quartz (1), pyrite, } \\
\text { organics (1) }\end{array}$ & $\begin{array}{l}\text { Top of turbidite; Chondrites } \\
\text { burrows are micrite-filled. }\end{array}$ \\
\hline
\end{tabular}

reaches a maximum of 15 events in $1.5 \mathrm{~m}$ (Core 107, Section 1) where turbidite flows make up nearly $90 \%$ of the sediment.

\section{Microfacies and Chemistry}

The limestones are composed of bioclasts and micrite pellets in a matrix or cement of microspar to spar (Fig. $24)$. The bioclasts are 10 to $25 \%$ of the volume and include calcified radiolarians, large mollusk fragments, foraminifers, echinoderm and shell debris, calcispheres, and pieces of calcareous algae (Table 9). Pellets and micritized grains comprise 15 to $45 \%$ of the sediment. Ooids are $10 \%$ of the bed at Core 106, Section 1, 134 $\mathrm{cm}$, and other beds may also be partially oolitic. The microspar to sparite matrix may either be recrystallized micrite or a later cementation of a pellet-bioclasts grainstone. Terrestrial silt or organics are essentially absent.
The carbonate content averages $87 \%$ with a range of 81 to $90 \%$ (4 analyses). Organic carbon content is a low $0.1 \%$.

\section{Discussion and Interpretation}

Several of these turbidites have shallow-water bioclasts and ooids. These, plus the abundant pellets, indicate that the source region was shallow-water shoals, an environment common on the present-day Bahama Banks.

The top of this turbidite series terminates abruptly in Core 103. This causes a change in bulk physical properties, which has been correlated with seismic reflection D' (Sheridan et al., this volume). The seismic reflection interval between $\mathrm{D}^{\prime}$ and underlying $\mathrm{D}$ is observed to thicken toward the Bahama Banks (Sheridan et al., this volume). Even though the shallow-water turbidites com- 


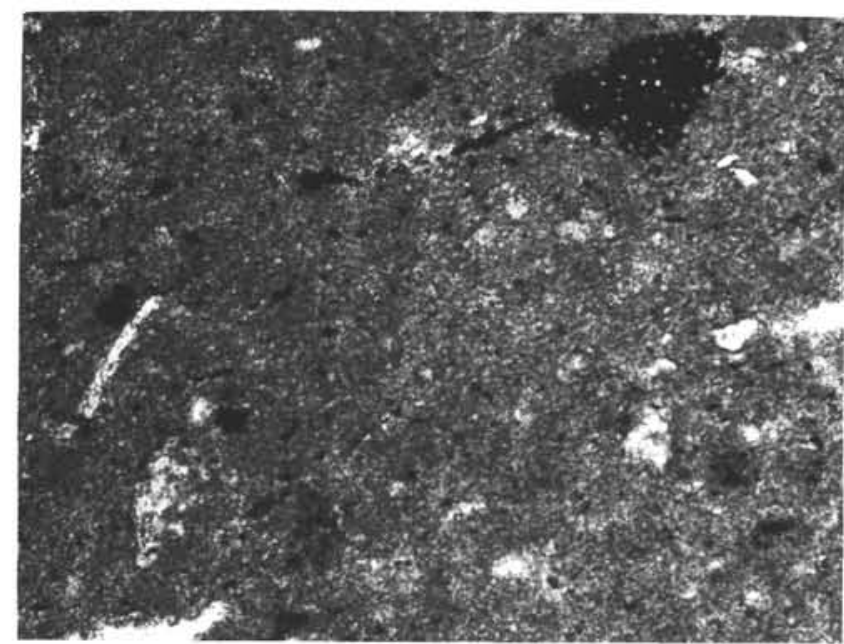

Figure 22. Photomicrograph of a thin section of a bioclastic micrite, vaguely pelletal, from the Oxfordian-late Callovian lime-rich turbidite interval-Sample 534A-122-1, $167 \mathrm{~cm}$. (At upper right is a pyritized radiolarian test, $80 \mu \mathrm{m}$ across. Other fragments of pyritized radiolarians and fine shell debris are common.)

pose less than $30 \%$ of the D-D' interval at Site 534 , the thickening and an increase in average velocity of this interval toward the south may represent an increase in the abundance and thickness of these turbidites. Thus the source could have been the ancient Bahama Banks, $220 \mathrm{~km}$ to the south. However, DSDP Site 100, located near the seaward edge of the Bahama Banks, has only fine-grained, pelletal turbidites in the recovered Kimmeridgian intervals, which suggests that either the coarse, shallow-water debris from the Bahamas was channalized perferentially northward toward Site 534 (as in the Great Abaco turbidite-debris flow episode in the Miocene) or the main source was instead the nearer Blake Plateau carbonate platform.
The shallow-water turbidite input is an episode occurring in the middle of the previously described interval of micritic turbidites. Therefore redeposition was occurring simultaneously from shallow shoals and the lower slope.

The coincidence of this turbidite activity with a regional sea-level rise will be discussed later.

\section{Summary of Jurassic Stratigraphy of Site 534}

The basal sediment above the tholeitic pillow basalt complex is middle to late Callovian ferrigenous brown marl. The overlying late Callovian and Oxfordian organic-rich dark claystone is also metalliferous in the lower portion; the source of this excess $\mathrm{Fe}$ and $\mathrm{Mn}$ is possible hydrothermal exhalations from the adjacent spreading ridge. The late Callovian sediments indicate a high influx of terrestrial silt and organic material, a gradual rise in the $\mathrm{CCD}$, variable bottom currents, slumping on an uneven topography, and fluctuating concentration and preservation of radiolarians.

Pelletal limestone turbidites from the Blake Plateau in the west gradually filled seafloor depressions, reaching the basement high of Site 534 late in the Callovian and continuing into the early Oxfordian.

The CCD dropped in the later part of the Oxfordian or early Kimmeridgian, allowing the deposition of greenish gray and reddish brown marl. Aragonite was preserved in Kimmeridgian and early Tithonian marl. Surface fertility remained low, but the carbonate banks in the Bahamas or Blake Plateau actively shed bioclastic pelletal turbidites. The site also received distal micritic turbidites probably from the Blake Plateau lower slope. As carbonate influx to the Site increased in the Late Tithonian, the sediments changed from red marl to pink marly limestone, then to white limestone at the close of the Jurassic. The CCD rose slightly, aragonite was no longer preserved, and iron was no longer oxidized to he-

Table 8. Microfacies of Hole 534A micrite turbidites (?Tithonian-Oxfordian).

\begin{tabular}{|c|c|c|c|c|}
\hline $\begin{array}{c}\text { Sample } \\
\text { (core-section, } \\
\mathrm{cm} \text { from top of section) }\end{array}$ & Lithology & Bioclasts $(\%)$ & $\begin{array}{l}\text { Silt-sized } \\
\text { components } \\
(\%)\end{array}$ & Comments \\
\hline $104-4,46$ & Micrite & Shell fragments (3) & Opaques, organics (2) & \\
\hline $104-4,73$ & Micrite & Shell fragments $(2-4)$ & & $\begin{array}{l}\text { Very fine microsparite texture; } \\
\text { bioclastic (shell fragments, } \\
\text { calcified radiolarians, cal- } \\
\text { cispheres) concentration in } \\
\text { burrows. }\end{array}$ \\
\hline $106-1,31$ & Micrite & $\begin{array}{l}\text { Calcispheres (1), fine shell } \\
\text { debris (1) }\end{array}$ & Opaques (1) & $\begin{array}{l}\text { Scattered micrite clusters (re- } \\
\text { placed fossils?) }(2 \%)\end{array}$ \\
\hline $108-1,6$ & Micrite & Shell fragments (rare) & & $\begin{array}{l}\text { Chondrites burrows at top are } \\
\text { slightly coarser and } \\
\text { darker. }\end{array}$ \\
\hline $110, \mathrm{CC}(1)$ & Micrite (pelletal?) & None & $\begin{array}{l}\text { Quartz }(1 \%) \text {, glau- } \\
\text { conite? (rare) }\end{array}$ & $\begin{array}{l}\text { Micrite may have fine pellets; } \\
\text { microspar clusters ( } 2 \%) \\
\text { may be replaced bioclasts. }\end{array}$ \\
\hline $111-1,7$ & Micrite & None & & $\begin{array}{l}\text { Microspar clusters }(2 \%) \text { may } \\
\text { be replaced radiolarians. }\end{array}$ \\
\hline $112-1,32$ & Micrite & $\begin{array}{l}\text { Calcified radiolarians } \\
\text { (rare) }\end{array}$ & Organics (rare) & \\
\hline $113-1,16$ & Micrite & $\begin{array}{l}\text { Calcified radiolarians } \\
\text { (rare), shell fragments } \\
\text { (rare) }\end{array}$ & $\begin{array}{l}\text { Quartz (1), chlorite } \\
\text { (rare), opaques } \\
\text { (2) }\end{array}$ & Vaguely pelletal. \\
\hline $113-1,30$ & Silty pelmicrite & $\begin{array}{l}\text { Radiolarians, shell frag- } \\
\text { ments, and echino- } \\
\text { derm plates (rare) }\end{array}$ & $\begin{array}{l}\text { Quartz (10), mica (3), } \\
\text { opaques (2) }\end{array}$ & Micrite pellets $(80 \%)$. \\
\hline
\end{tabular}




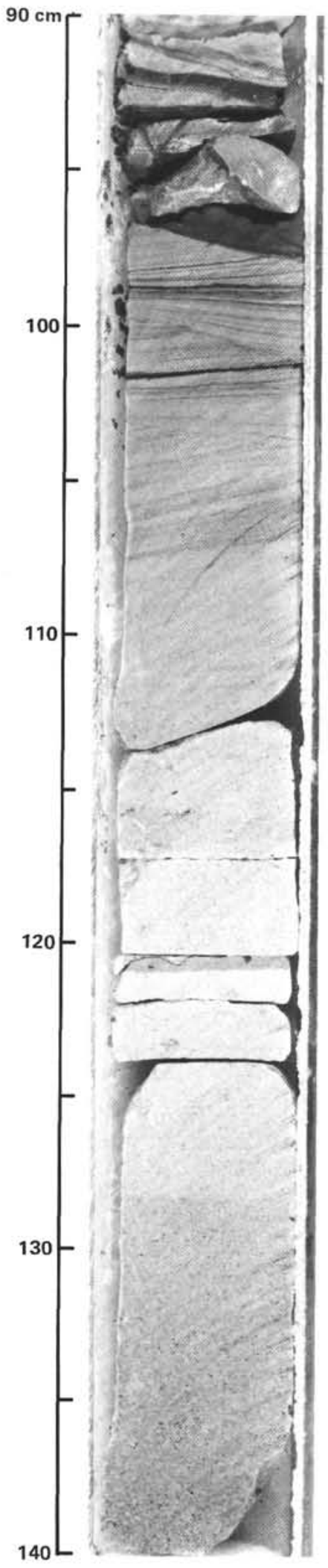

Figure 23. Turbidite bed of bioclastic pelletal microsparite limestone in the Kimmeridgian-?Tithonian turbidite unit. (Grading and current cross-lamination are well-developed. The lower bed contains $10 \%$ ooids, $20 \%$ pellets, and over $15 \%$ shallow-water bioclasts including algal fragments and mullusk shells. (Sample 534A-106-1, $90-140 \mathrm{~cm}$.)

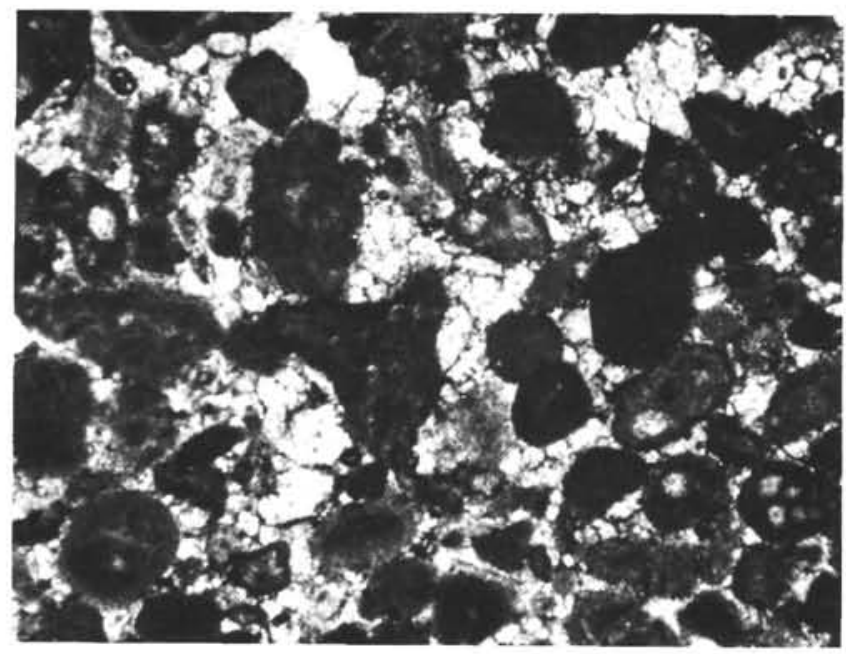

Figure 24. Photomicrograph of a thin section (Sample 534A-106-1, $134 \mathrm{~cm}$ ) from near the base of the turbidite bed in Figure 23. (Ooids, pellets, composite pelletal grains, and bioclasts are loosely packed in a sparry calcite cement. Bioclasts include shell fragments, foraminifers, and algal fragments. The thin section is 1.7 mm across.)

matite. Deposition of white limestone continued into the Early Cretaceous.

\section{PART TWO-JURASSIC SEDIMENTS OF THE NORTH ATLANTIC OCEAN BASIN AND MARGINS}

The Jurassic strata in the North Atlantic are known from two different geographic provinces: (1) deep oceanic basin and (2) continental shelf and slope. Here we describe the Jurassic sediments separately from each of the geographic provinces and the correlation to the stratigraphy of Site 534 .

\section{North Atlantic Basin}

Previous to drilling at Site 534, Jurassic sedimentary rocks in the Atlantic were recovered at six other DSDP sites: Sites 99, 100, 105 (Hollister, Ewing, et al., 1972) and Site 391 (Benson, Sheridan, et al., 1978) are located in the western North Atlantic (North American Basin), and Site 367 (Lancelot, Seibold, et al., 1978) and Site 416 (Lancelot, Winterer, et al., 1980) are located in the eastern North Atlantic (Fig. 25). Of these, Site 416 recovered predominantly a clastic and calcareous turbidite sequence representing a lowermost continental rise depositional environment of latest Late Jurassic through Early Cretaceous; therefore this Site will not be examined here. DSDP Leg 79 recovered Jurassic sediments in the eastern North Atlantic, but only preliminary results were available at the time this chapter was being written.

Detailed stratigraphic studies in the North American Basin demonstrated that Mesozoic-Cenozoic deposition reflected basin-wide oceanographic changes; consequently, major lithofacies can be correlated from site to site. Lancelot et al. (1972) recognized three Jurassic sediment facies units: greenish gray homogeneous marly limestone, reddish marly limestone, and Tithonian-Neo- 
Table 9. Microfacies of Hole 534A bioclastic pelsparite turbidites (Kimmeridgian-?Oxfordian).

\begin{tabular}{|c|c|c|c|c|}
\hline $\begin{array}{c}\text { Sample } \\
\text { (core-section, } \\
\mathrm{cm} \text { from top of section) }\end{array}$ & Lithology & Bioclasts $(\%)$ & Other $(\%)$ & Comments \\
\hline $103-1,133$ & $\begin{array}{l}\text { Bioclastic pelmicro- } \\
\text { sparite }\end{array}$ & $\begin{array}{l}\text { Calcified radiolarians (6), calci- } \\
\text { spheres (3), shell fragments } \\
\text { (2), echinoderm debris (1), } \\
\text { unidentifiable (3) }\end{array}$ & & $\begin{array}{l}\text { Vaguely pelletal; microspar } \\
\quad(50 \%) \text {. }\end{array}$ \\
\hline $104-1,82$ & $\begin{array}{l}\text { Radiolarian pel- } \\
\text { microsparite }\end{array}$ & $\begin{array}{l}\text { Calcified radiolarians (25), } \\
\text { shell fragments (rare) }\end{array}$ & & $\begin{array}{l}\text { Thin limestone layer; some radio- } \\
\text { larians are pyrite-replaced; } \\
\text { pellets }(15 \%) \text {, microspar } \\
(55 \%) \text {. }\end{array}$ \\
\hline $105-1,82$ & $\begin{array}{l}\text { Bioclastic pelmicro- } \\
\text { sparite (oolitic?) }\end{array}$ & $\begin{array}{l}\text { Shell fragments (10), echino- } \\
\text { derm and foraminifer de- } \\
\text { bris (5) }\end{array}$ & & $\begin{array}{l}\text { Sand-sized pellets }(55 \%) \text { are de- } \\
\text { formed in many cases, often } \\
\text { having oolitelike structure; } \\
\text { microspar }(30 \%) \text {. }\end{array}$ \\
\hline $106-1,134$ & $\begin{array}{l}\text { Bioclastic pelspar- } \\
\text { ite (oolitic) }\end{array}$ & $\begin{array}{l}\text { Shell (mollusk) (8), echinoderm } \\
\text { debris (5), algae fragments } \\
\text { (3), foraminifers (1) }\end{array}$ & $\begin{array}{l}\text { Ooids (10), } \\
\text { organics (2) }\end{array}$ & $\begin{array}{l}\text { Pellets and composite grains }= \\
22 \% ; \text { spar }=50 \% ; \text { silicifica- } \\
\text { tion of some replaced } \\
\text { mollusks. }\end{array}$ \\
\hline $109, \mathrm{CC}(7)$ & Bioclastic pelsparite & $\begin{array}{l}\text { Mollusk fragments (5), fora- } \\
\text { minifers (3), echinoderm } \\
\text { debris (2) }\end{array}$ & Quartz (1) & $\begin{array}{l}\text { Pellets and micritized grains }= \\
45 \% ; \text { microspar and spar }= \\
45 \% \text {. }\end{array}$ \\
\hline
\end{tabular}

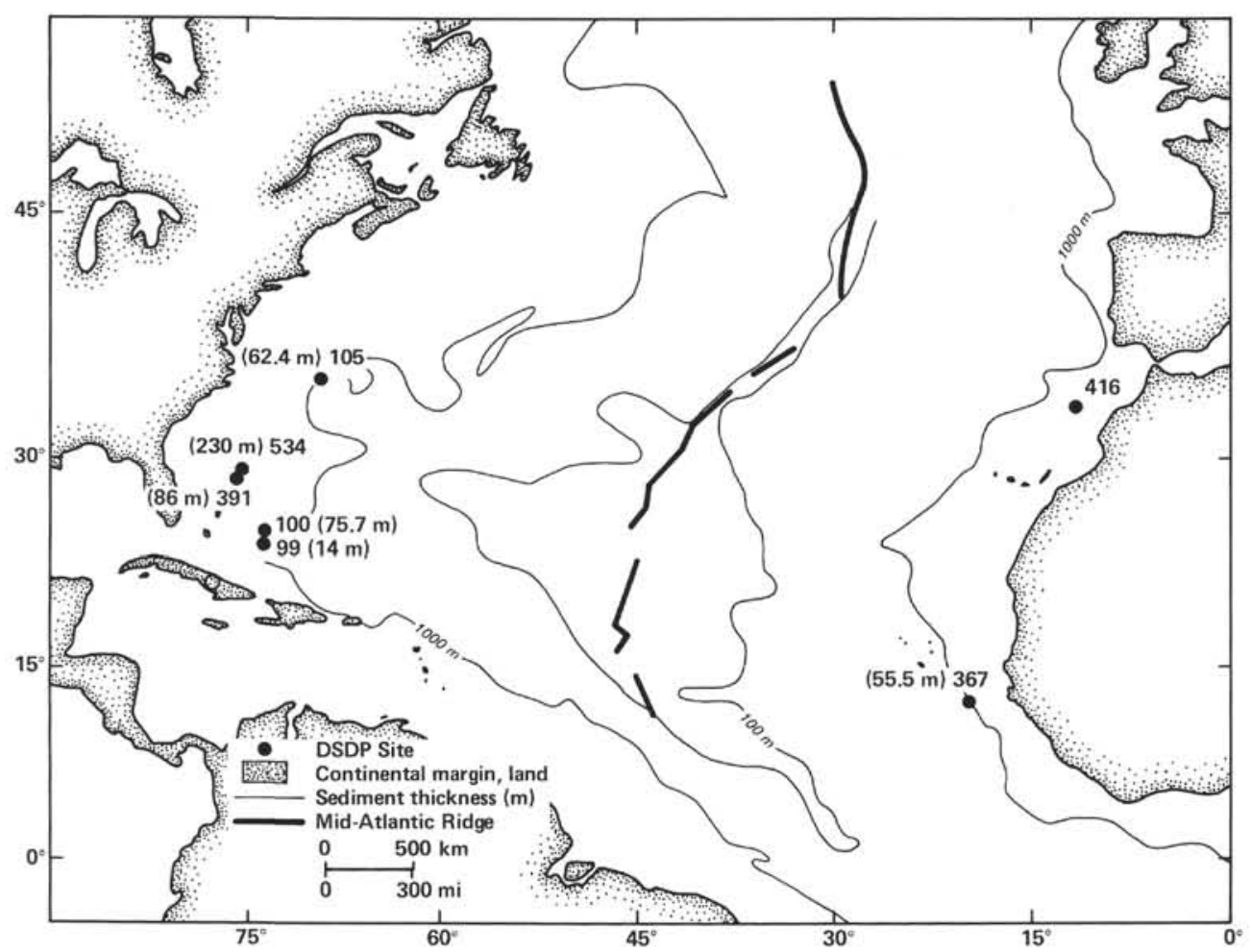

Figure 25. Location of DSDP sites that penetrated the Cat Gap Formation or the coeval reddish brown marly limestone lithofacies in the North Atlantic.

comian white and gray limestones. Jansa et al. (1979) reviewed the lithologic and seismic stratigraphic correlations and placed these lithofacies units into a formal stratigraphic framework: the Cat Gap Formation encompasses the greenish gray and overlying reddish brown marly limestones, and the Blake-Bahama Formation, the overlying light gray limestone (Fig. 26). Many marine geologists still question the need for the formation framework and prefer the lithofacies concept.

In this summary of the Jurassic of the North Atlantic Basin we have combined the concepts of the lithofacies and formations, the main reason being that even though similar sediments are known to have been deposited in the western and eastern North Atlantic during the Mesozoic (Jansa et al., 1978) the separation of areas of sedi- mentation by the process of seafloor spreading means that sedimentary "formations" cannot be followed across the whole oceanic basin.

\section{North American Basin-Cat Gap Formation}

Reddish brown and greenish gray marl and marly limestone is the characteristic Late Jurassic deposit (Table 10). This Cat Gap Formation has been described in detail by Lancelot et al. (1972) and Jansa et al. (1979), therefore only a summary will be given here.

\section{Greenish Gray Marly Limestone and Marl Subfacies of the Cat Gap Formation}

Relatively homogeneous, greenish gray marly limestone and marl $42 \mathrm{~m}$ thick was the lowest sediment unit 


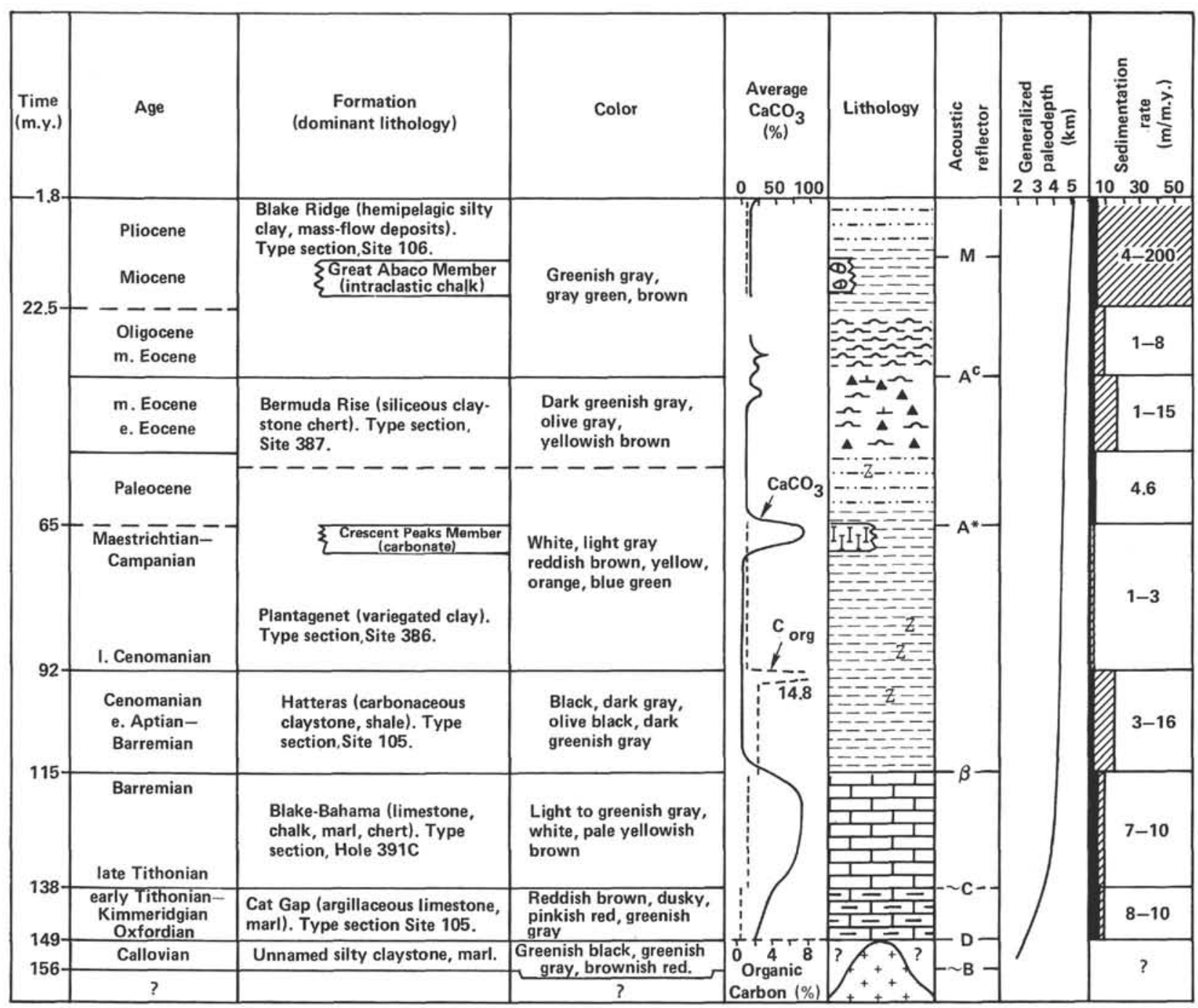

Figure 26. Updated stratigraphy for the North American Basin incorporating data from Site 534.

Table 10. Geographic distribution of the Cat Gap Formation in the North American Basin.

\begin{tabular}{|c|c|c|c|c|c|c|c|}
\hline \multirow[b]{2}{*}{ Region } & \multirow[b]{2}{*}{$\begin{array}{l}\text { DSDP } \\
\text { Leg }\end{array}$} & \multirow[b]{2}{*}{ Site } & \multicolumn{4}{|c|}{ Cat Gap Formation } & \multirow[b]{2}{*}{ Position } \\
\hline & & & $\begin{array}{c}\text { Top } \\
\text { (m, } \\
\text { sub-bottom } \\
\text { depth) }\end{array}$ & $\begin{array}{c}\text { Base } \\
\text { (m, } \\
\text { sub-bottom } \\
\text { depth) }\end{array}$ & $\begin{array}{l}\text { Thickness } \\
\text { (m) }\end{array}$ & $\begin{array}{c}\text { Age } \\
\text { estimate }\end{array}$ & \\
\hline $\begin{array}{l}\text { Lower continental } \\
\text { rise }\end{array}$ & 11 & $105^{\mathrm{a}}$ & 559.8 & $622.2 \mathrm{~B}^{\mathrm{a}}$ & 62.4 & $\begin{array}{l}\text { Tithonian- } \\
\text { Oxfordian }\end{array}$ & $34^{\circ} 53.7^{\prime} \mathrm{N}, 69^{\circ} 10.4^{\prime} \mathrm{W}$ \\
\hline Cat Gap area & 11 & 99 & $234^{b}$ & $248 \mathrm{TD}^{\mathrm{d}}$ & $>14$ & $\begin{array}{l}\text { Kimmeridgian- } \\
\text { Oxfordian }\end{array}$ & $23^{\circ} 41.1^{\prime} \mathrm{N}, 73^{\circ} 51.0^{\prime} \mathrm{W}$ \\
\hline Cap Gap area & 11 & 100 & $238^{\mathrm{c}}$ & $313.7 \mathrm{~B}^{\mathrm{e}}$ & 75.7 & $\begin{array}{l}\text { Kimmeridgian- } \\
\text { Oxfordian }\end{array}$ & $24^{\circ} 41.3^{\prime} \mathrm{N}, 73^{\circ} 47.9^{\prime} \mathrm{W}$ \\
\hline $\begin{array}{l}\text { Blake-Bahama } \\
\text { Basin }\end{array}$ & 44 & 391 & 1326 & $1412 \mathrm{TD}^{\mathrm{d}}$ & $>86$ & $\begin{array}{l}\text { Tithonian-late } \\
\text { Kimmeridgian }\end{array}$ & $28^{\circ} 13.7^{\prime} \mathrm{N}, 75^{\circ} 36.9^{\prime} \mathrm{W}$ \\
\hline $\begin{array}{l}\text { Blake-Bahama } \\
\text { Basin }\end{array}$ & 76 & 534 & 1342 & 1572 & 230 & $\begin{array}{l}\text { Tithonian- } \\
\text { Oxfordian }\end{array}$ & $28^{\circ} 20.6^{\prime} \mathrm{N}, 75^{\circ} 22.9^{\prime} \mathrm{W}$ \\
\hline
\end{tabular}

Note: For more information, see Jansa et al. (1979).

a Type locality of the Cat Gap Formation.

$\mathrm{b}$ Based on seismic reflector and reduction in drilling rate; the interval from 202 to $235 \mathrm{~m}$ was not cored.

c Based on reduction in drilling rate; the interval from 212 to $238 \mathrm{~m}$ was not cored.

d Denotes total depth penetrated; bottom of formation not cored.

$\mathrm{e}$ Indicates that the formation rests directly on basement.

penetrated at Site 100 in the Blake-Bahama Basin. The mineralogy consists of euhedral calcite, a variable amount of montmorillonite, palygorskite, kaolinite, mica, K-feldspar, and rare quartz (Zemmels et al., 1972), and a variety of bioclasts. Pelagic bivalve shells have the appearance of short filaments in thin section.
Additional microfossils include minor Globochaete, calcispherulids, echinoid fragments, and planktonic crinoid Saccocoma. Arenaceous foraminifers, globigerinids, ostracodes, radiolarians, and aptychi are rare (Luterbacher, 1972). Common plant fragments and stratigraphically mixed dinoflagellate assemblages (Habib, 1972) are 
enclosed in the limestones. Millimeter-thick laminae of silt-sized peloid grains, which are considered to represent carbonate turbidites, occur at a few levels.

The depositional environment is a pelagic realm above the CCD with introduction of shallow-water and continent-derived material into the basin by turbidity currents.

The age of the greenish gray marly limestone subfacies at Site 100 has been the subject of wide disagreement and was initially thought to be Callovian at the base. The location of Site 100 is $25 \mathrm{~km}$ west of Marine Magnetic Anomaly M-25 (Larson and Hilde, 1975), which probably formed in the latest Oxfordian (Ogg et al., unpublished data), therefore the basal age of the sediments is probably also late Oxfordian. Older fossil material is probably redeposited. The probable age of late Oxfordian-Kimmeridgian better corresponds to the similar lithofacies unit at Site 534.

\section{Reddish Brown Marl and Marly Limestone Lithofacies of the Cat Gap Formation}

The greenish gray limestone at Site 100 grades upward into reddish brown marl and marly limestone. This lithofacies was penetrated also at Sites 99, 105, and 391 (Table 10). The "type section" at Site 105 displays an upward trend of increasing carbonate content, from a lower calcareous claystone or marl into marly limestone above. Similar trends were observed at Sites 391 and 534. The marly limestone is a mixture of neomorphic micrite and clay minerals (mica, montmorillonite, and kaolinite or chlorite in traces), with minor components of quartz, feldspars, zeolites, hematite, pyrite, and heavy minerals.

The organic carbon content averages only $0.1 \%$. Red color (dark reddish brown to pale red) characterizes the more clay-rich beds; gray and greenish colors, the more carbonate-rich beds. The commonly patchy occurrence of gray green colors is associated with burrows and bedding planes in which the iron is reduced.

Sedimentary structures include laminated layers, incipient white limestone clasts associated with undulatory laminations, turbidite beds of pelagic material (these dominate the lower part of the section at Site 105), and slump structures (Lancelot et al., 1972).

Microfossils of the Cat Gap Formation include wellpreserved nannoplankton, sparse to rich foraminiferal fauna, poorly preserved radiolarians, calcispheres, ostracodes, and dinoflagellates. Jansa et al. (1979) subdivided the Formation at Site 105 into a "filaments" (pelagic bivalves) microfacies (Cores 105-36 to 37, Fig. 27C) and an overlying Saccocoma microfacies (Cores 105-36 to 33, Fig. 27D) on the basis of these characteristic fauna.

It must be noted that the microfossils in these limestones and marls are, as a rule, rare and are usually noticed only when concentrated into thin laminae either by weak bottom currents or by bioturbation. The microfossils, such as the "filaments," Saccocoma debris, radiolarians, or calpionellids, may comprise up to 30 to $40 \%$ in such laminae. However, the next lamina or layer can be completely devoid of these fossils. This sub- division into "filament" and Saccocoma microfacies is less distinct at sites other than Site 105.

Aragonite needles and pieces of ammonite shells were found at Sites 391 and 534, but at other sites only the calcite aptychi of ammonites are present. This fact suggests that the regional ACD during part of the Kimmeridgian was significantly lower in the Blake-Bahama Ba$\sin (3300-3700 \mathrm{~m}$ estimated paleodepth range during the Kimmeridgian to the early Tithonian) than at the slightly shallower more seaward sites (2700-3300 m estimated paleodepth range). Abundant small ammonites were found in a zone in the Kimmeridgian red marl at Site 99 (Core 14, Section 2, $27 \mathrm{~cm}$ ).

Regional patterns of sedimentation rate or productivity are difficult to derive because of the limited distribution of sites and the presence of hiatuses. Site 105 has a late Tithonian hiatus between the Cat Gap Formation and the overlying Berriasian portion of the Blake-Bahama Formation, whereas Site 534 has continuous sedimentation though the Tithonian, but probably has a major late Kimmeridgian hiatus (see the discussion in Ogg, this volume). At other sites, dating and recovery are inadequate to identify hiatuses. It does appear, however, that the sedimentation rate of the reddish brown marly limestone lithofacies at Sites 534 and 391 was much higher than at the other sites (Fig. 25), implying a relatively greater influx of both carbonate and terrigenous clay into the Blake-Bahama Basin.

The age span of the reddish brown marl subfacies of the Cat Gap Formation can be broadly interpreted as latest Oxfordian to early late Tithonian. The biostratigraphic and magnetostratigraphic data are inadequate to identify any evidence of time transgression of the boundaries between sites.

\section{Eastern Central Atlantic-Reddish Brown Marly Limestone Lithofacies}

A lithofacies similar to that of the Cat Gap Formation was penetrated $(55.5 \mathrm{~m})$ in the Cape Verde Basin at Site 367 (Lancelot, Seibold, et al., 1978). At this Site this lithofacies is more calcareous $\left(44-99 \% \mathrm{CaCO}_{3}\right)$ than that found in the North American Basin, and it is dominated by locally nodular marly limestones (Fig. 27A), which are intercalated with marls and minor chert beds and nodules. In the lower part of the unit, the reddish brown limestone alternates with greenish gray to light olive gray limestone and claystone beds, which may have affinities to the greenish gray subfacies as encountered in the North American Basin. In the upper part of the lithofacies the microcrystalline limestone is light brownish gray to dark reddish brown, alternating with pink and light gray. Bioturbation and fine wavy lamination are common.

The clays are dominated by smectite and mixed layers, with a minor amount of illite (Mélières, 1978). Quartz occurs locally as chalcedony. In contrast to the Jurassic of the western North Atlantic, feldspars are lacking, which suggests minimal input of terrigenous clastics into this part of the Basin.

Three distinct microfossil facies were identified (Jansa et al., 1978): a radiolarian microfacies $(7 \mathrm{~m}$ thick, 

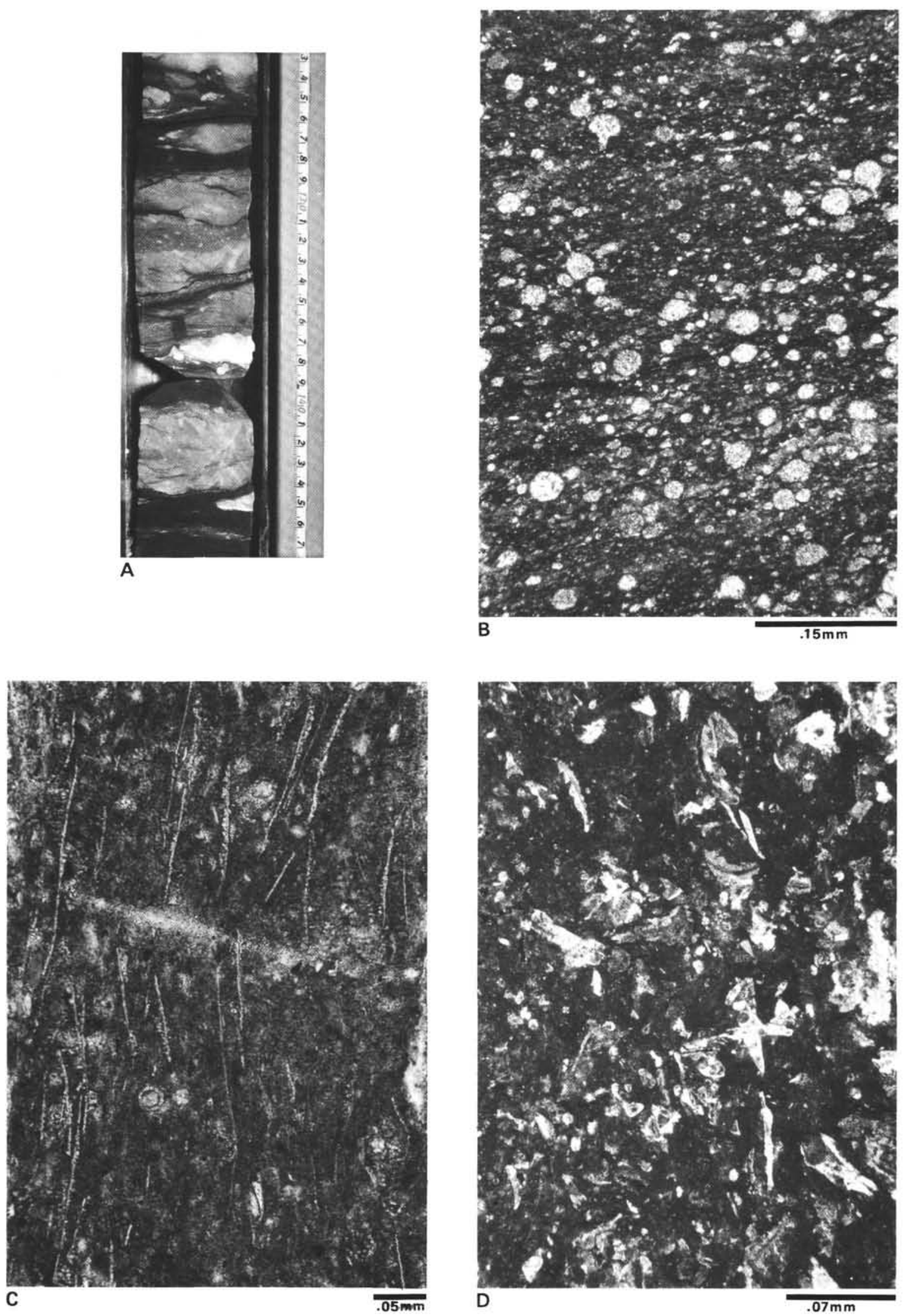

Figure 27. A. Late Jurassic, reddish brown, slightly nodular limestone from Cape Verde Basin, Site 367. B. Radiolarian microfacies, Site 236. C. "Filaments" microfacies, Site 105. D. Saccocoma microfacies, Site 105. 
overlying basalt), a "filament" microfacies (13.5 m thick), and a Saccocoma microfacies ( $35 \mathrm{~m}$ thick). Other biogenic components include foraminifers, sponge spicules, calcispheres, aptychi, and echinoderm debris. The microfacies are much better developed than those in the North American Basin, perhaps reflecting relatively higher fertility off the African margin during the late Jurassic. The contact between the radiolarian and "filament" microfacies is gradational; the boundary with the overlying Saccocoma microfacies is sharp, though there is no visible macroscopic difference between these two subunits. The upper contact of the reddish brown marly limestone lithofacies to the overlying light gray limestone lithofacies is sharp, perhaps representing a Tithonian hiatus (the apparent thickness of the Tithonian is less than $4 \mathrm{~m}$ ).

The age span of the recovered reddish brown marly limestone unit is Oxfordian to Kimmeridgian (Site 367 was drilled slightly east of M-25, suggesting a basement age of late Oxfordian).

\section{Contribution of Site 534 to the Extension of the Jurassic Stratigraphic Framework of the Central North Atlantic}

Site 534 contributes to our understanding of the Jurassic stratigraphy of the central North American Basin by extending our knowledge of the evolution of the lower part of the Cat Gap Formation and revealing the character of older lithologic units deposited in the Ba$\sin$. The sediment stratigraphy of the western central North Atlantic is summarized in Figure 28.

\section{Basal Unnamed Unit}

The greenish black silty claystone-brown silty marl unit (Site 534, Core 120 through Sample 127,CC [10 $\mathrm{cm}]$ ) is the oldest Jurassic unit yet recovered in the North Atlantic. Its lithological composition and color are quite different from those of the Cap Gap Formation as defined in the North American Basin by Jansa et al. (1979).

The lithologic change that was observed near the base of this unit may be of greater regional significance than can be realized from a single site. In Core 126 the basal reddish brown marl subunit grades upward into the greenish black claystone. The carbonate content drops from 20 to less than $5 \%$. The microfacies of the reddish brown marl is characterized by local concentrations of pelagic bivalves ("filament"), whereas the overlying greenish black claystone has concentrations of radiolarians.

The shipboard scientific party suggested that this lithological difference is possibly caused by a lower influx of organic material or more oxidizing bottom waters, and higher carbonate productivity, greater nannofossil preservation, or a lower CCD relative to the overlying claystones. Later we discuss the possibility that these changes correlate to an active phase of the Callovian transgression.

\section{Cat Gap Formation Redefinition}

Previous to drilling at Site 534, the Cat Gap Formation was subdivided into two main lithofacies: the Kim- meridgian-early Tithonian reddish brown marls and limestones, and ?Oxfordian-Kimmeridgian greenish gray marl. The latter lithofacies was penetrated only at Site 100 and thus it was not certain if this lithofacies was of regional or only of local significance. Its presence at Site 534 indicates that this greenish gray marl subunit is regional in extent, covering at least the Blake-Bahama Basin.

Between the greenish gray marl unit and the greenish black silty claystone-brown marl basal unit of Site 534 are over $75 \mathrm{~m}$ of variegated claystone with intercalated lime-rich turbidites. This unit resembles the underlying greenish black silty claystone in having organic-rich horizons, but the virtual absence of any microfossils, especially radiolarians, and the insignificant content of terrestrial silt imply a very different depositional environment. A major hiatus is suspected to be the cause of the sharp lower contact. The upper portion displays a gradual increase in carbonate content, which suggests that a transition to the overlying greenish gray marl may exist but was not recovered.

At previous DSDP sites, drilling had terminated with the Cat Gap Formation (without reaching older strata indicated by seismic data) or penetrated the Formation where it was underlain by oceanic volcanic basement. Therefore, in proposing a formal stratigraphic framework for the Mesozoic-Cenozoic of the North American Basin, the lower part and lower contact of the Cat Gap Formation remained undefined (Jansa et al., 1979). The Site 534 results show that the previously unknown sedimentary sequence is lithologically variable, but some of the Cat Gap Formation criteria, such as dominance of the reddish brown color, are found to extend into stratigraphically older strata. A distinct lithologic unit of greenish black silty claystones is found at the basal part of the section. Poor recovery and abundance of calcareous turbidite horizons make placement of boundaries difficult and arbitrary. After lengthy discussions, the top of the greenish black silty claystone unit was selected as the best lower boundary of a new stratigraphically extended Cat Gap Formation. This decision places the variegated claystone unit within the Cap Gap Formation. The boundary, as now established, is approximately correlatable $( \pm 20 \mathrm{~m})$ to seismic Horizon D, which is widely distributed with recognizable character in the Blake-Bahama Basin; however, this seismic horizon is considered to correlate with the top of the calcareous turbidite influx, not to the top of the greenish black silty claystone (Sheridan et al., this volume). Until a second hole penetrates a stratigraphic sequence similar to that at Site 534, the revision of the Cat Gap Formation presented here is to be considered as very probable, but not final.

\section{Atlantic Margins}

\section{Eastern North American Margin}

Information about development of the eastern North American margin during the Jurassic is provided by over 100 oil exploratory wells drilled during the past 15 yr. on the margin and by extensive multichannel seismic reflection surveys of the margin (McIvor, 1972; Jansa 


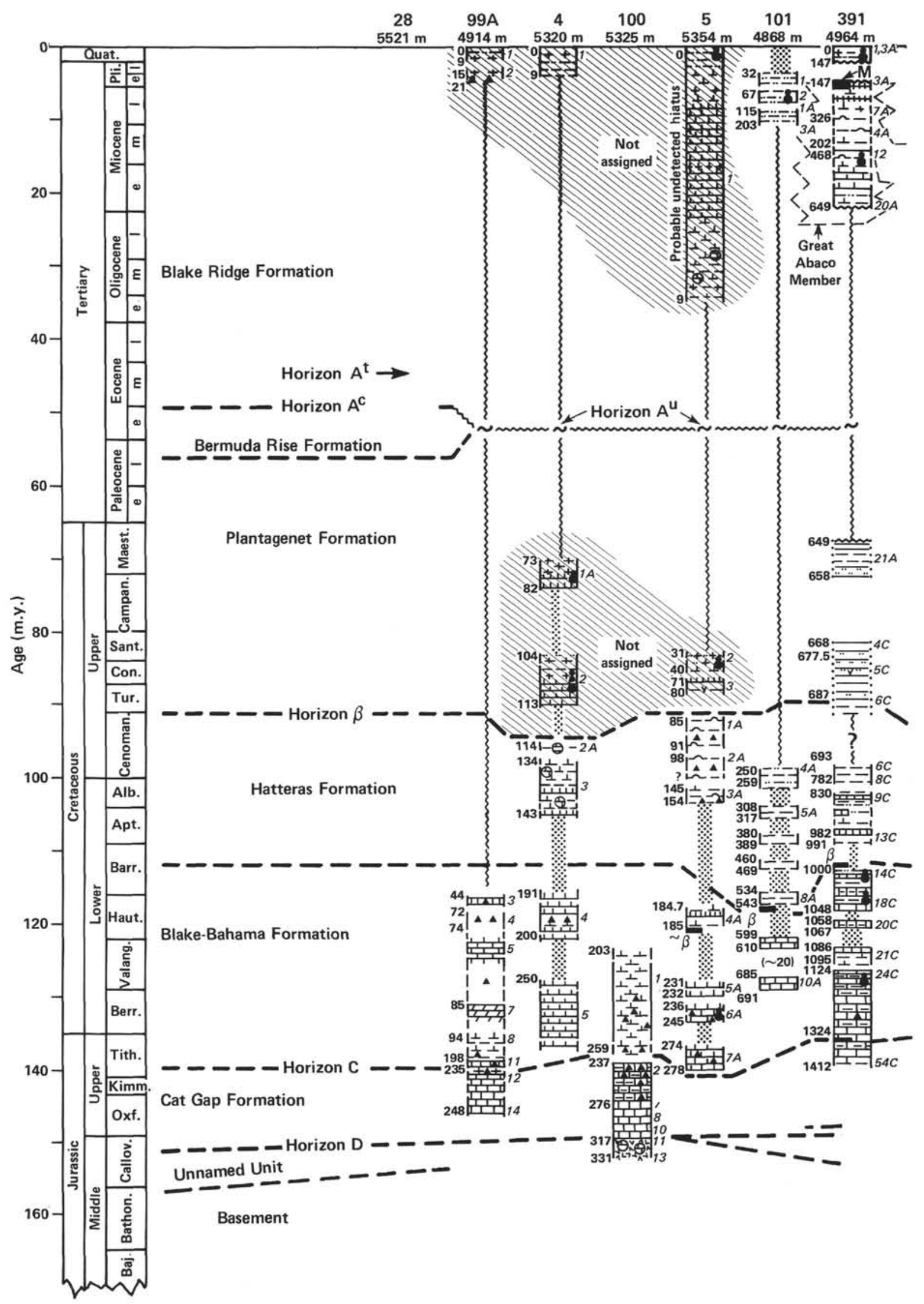

Figure 28. Correlation chart of the DSDP sites that penetrated Jurassic strata in the North American Basin. 


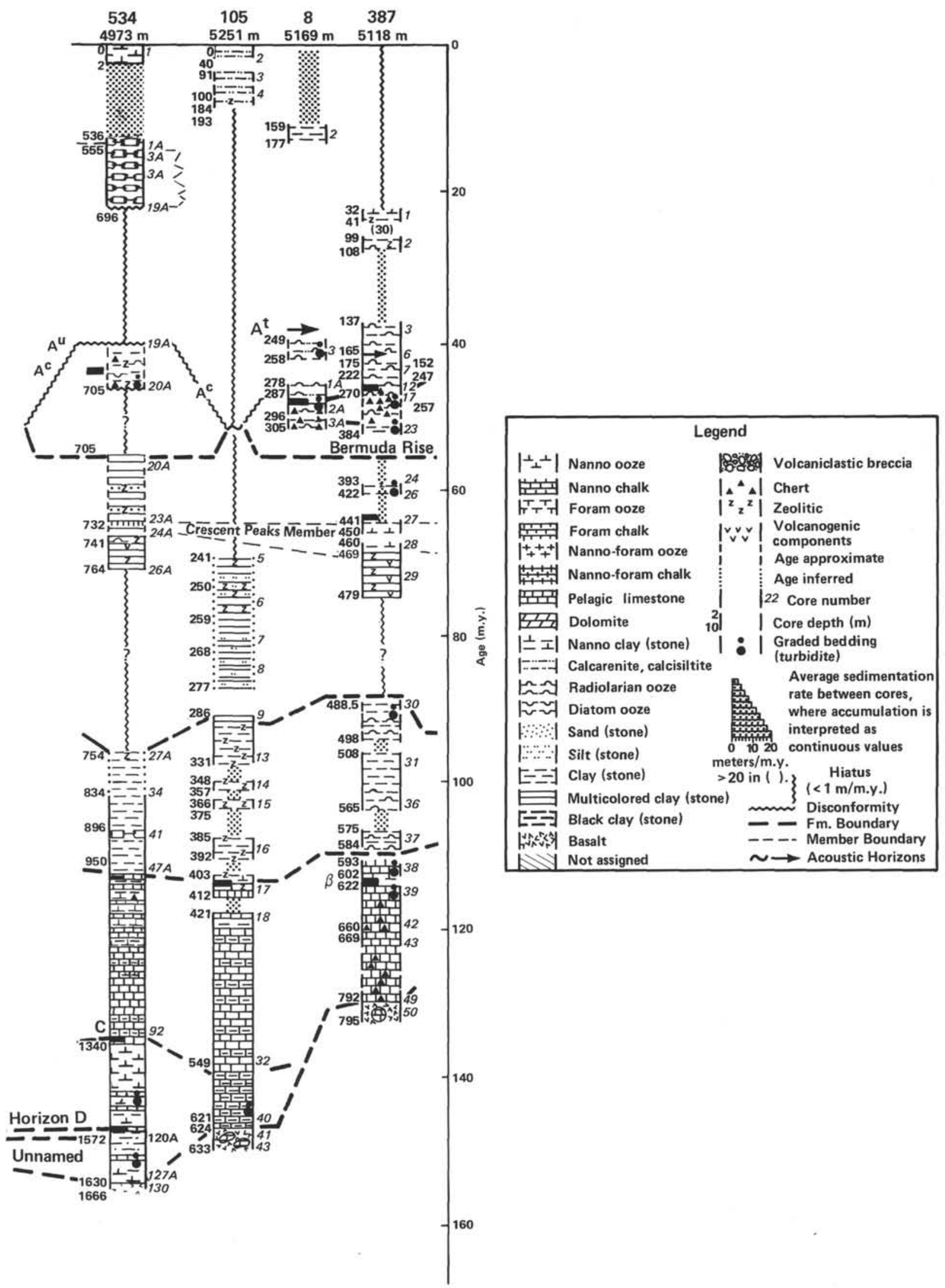

Figure 28. (Continued). 


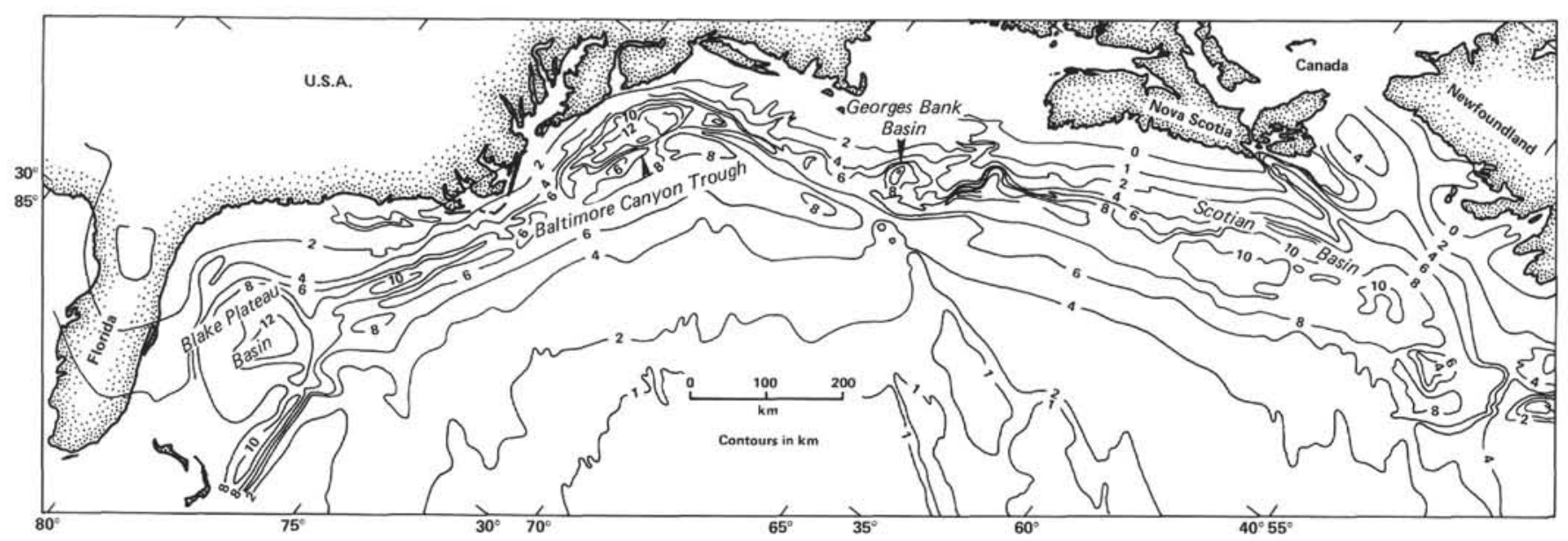

Figure 29. Isopach map of the Mesozoic-Cenozoic sediments of the eastern North American margin with location of the sedimentary basins.

and Wade, 1975; Schlee et al., 1976; Klitgord and Behrendt, 1979; Amato and Simonis, 1980; Amato and Simonis, 1979; Scholle, 1977, 1979). Such studies documented the existence of sedimentary basins filled by more than $14 \mathrm{~km}$ of Mesozoic-Cenozoic sediments extending along the margin (Fig. 29). Extensive Jurassic strata have been penetrated only in the two northern basins-the Scotian (Fig. 30) and Georges Bank basins-and are summarized in McIvor (1972), Jansa and Wade (1975), Given (1977), and Amato and Simonis (1980). In the Baltimore Canyon Trough only the Kimmeridgian-Tithonian strata are known, and in the Blake Plateau Basin only the Lower Cretaceous strata were penetrated by the drill. Sedimentary formations can be intercorrelated through several basins (Judkins et al., 1980; Schlee and Jansa, 1981; Jansa and Wiedmann, 1982). Thus depositional conditions can be inferred for the older parts of the older Mesozoic sedimentary sequences that have not yet been drilled in the southern basins.

\section{Scotian and Georges Bank Basins}

The oldest Jurassic sediments are evaporites intercalated with reddish-colored silty claystone (the Argo Formation), which overlie several hundred to several thousand meters of thick Triassic red beds (Figs. 30 and 34). The evaporites have been dated as Rhaetian to Hettangian-Sinemurian (Barss et al., 1979) and are overlain by ?Sinemurian to Bajocian shallow-water carbonates (the Iroquis Formation). The carbonates reflect a deepening of the depositional environment from a semirestricted tidal flat (dolomites and stromatolites) to an open marine subtidal environment (oolites and bioclastic limestones). Carbonate deposition was gradually replaced during the late Bajocian by a clastic wedge of alternating fine- to coarse-grained sandstones and variegated shale (the Mohican Formation). This clastic influx resulted from tectonic uplifting on the northwestern flank of the Basin, perhaps related to the initial stages of continental rifting in the Central Atlantic (Jansa and Wade, 1975).

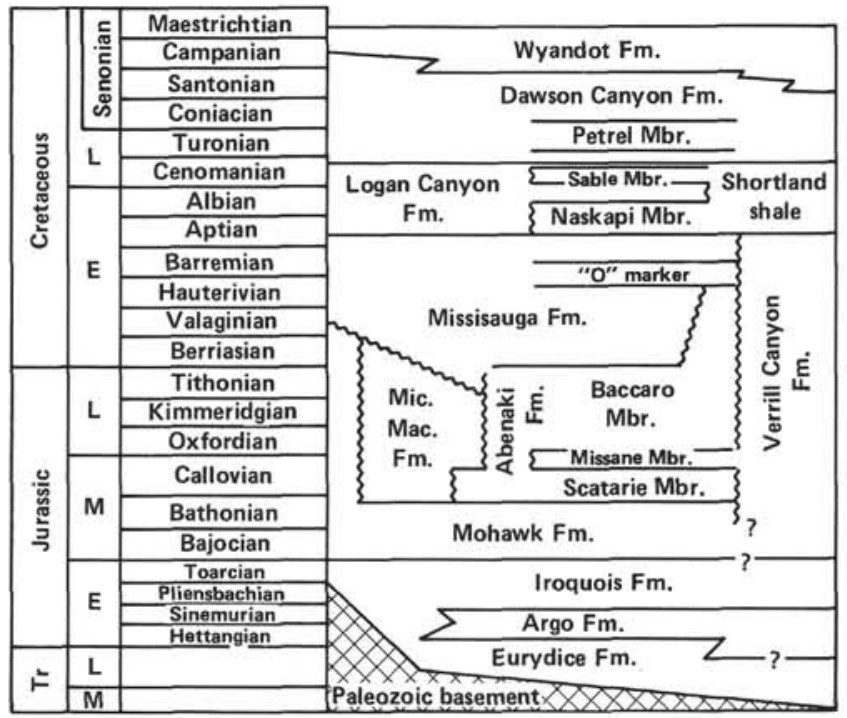

Figure 30. Stratigraphy of the Mesozoic-Cenozoic in the Scotian Basin. (Jagged line represents time-transgressive facies.)

Carbonate sedimentation resumed during the late $\mathrm{Ba}-$ thonian when a transgressive blanket of high-energy carbonates (the Scatarie Member of the Abenaki Formation) was deposited along the outer part of the margin. Carbonate deposition was briefly interrupted by an ingression during the Callovian, when neritic conditions led to sedimentation of more than $100 \mathrm{~m}$ of dark olive gray shale (the Misaine Member), then resumed in the Oxfordian (the Baccaro Member). Carbonate deposition became increasingly restricted to the outer shelf during the Late Jurassic, with offshore banks developing near the paleoshelf edge at the end of the Jurassic (Eliuk, 1978; Jansa, 1981), and was terminated by a continuing regression and local tectonic uplift during the Tithonian-Berriasian-Valanginian, as the carbonate banks were covered by prograding clastics (Missisauga Formation and Logan Canyon Formation). Deposits coeval to the Late Jurassic carbonates near the basin 
margin were continental clastics (the Mohawk Formation) as well as the marginal marine clastics (the Mic Mac Formation).

\section{Southern Basins}

The development of the Jurassic in the southern margin basins (Baltimore Canyon Trough and Blake Plateau) is incompletely known. Two wells in the Baltimore Canyon Trough, COST B-2 and B-3 (Smith et al., 1976; Scholle, 1977; Amato and Simonis, 1979), bottomed in Kimmeridgian clastic sequences composed of interbedded sandstones, siltstones, shale, and coal. The facies development suggests there was an alluvial plain more than $120 \mathrm{~km}$ wide and extending almost up to the present shelf edge.

A 500-m-thick zone of Tithonian shallow-water carbonates is intercalated with clastics in the COST B-3 well. This carbonate wedge and seismic profiles suggest a major offshore carbonate bank located seaward of COST B-3 (Fig. 31) (Grow et al., 1979) that lasted into the Early Cretaceous, with a "reef"' during the terminal stage. The Lower Cretaceous of both Baltimore Canyon Trough COST wells is characterized by deposition of deltaic clastics.

There is no direct evidence regarding the nature of the Jurassic rocks in the Blake Plateau Basin. From seis- mic evidence (Shipley et al., 1978), it is very probable that most of the Blake Plateau is underlain by a Jurassic-Cretaceous carbonate platform similar to the $\mathrm{Ba}$ hama Banks (Dillon et al., 1979) (Fig. 32). The presence of Lower Cretaceous clastics in the landward portion of the Basin (Amato and Bebout, 1980) suggests a development of sediment facies similar to the northern basins. However, the carbonate platform at the Blake Plateau Basin was broader and continued further into the Cretaceous (Jansa, 1981), with the clastics restricted to the nearshore part of the Basin. In all of these basins the carbonate platforms acted as effective barriers for trapping the clastics on the shelf, which contributed to the upward building of the margin.

\section{Northeast African Margin}

A pattern of alternating basins and basement highs typified the passive continental margin of northeast Africa during the Jurassic. From north to south, the basins are the Essaouira-Agadir (Atlas) Basin, TarfayaAaiun Basin, and Senegal Basin (Fig. 33). The JurassicEarly Cretaceous sedimentation history of the margin is known from surface exposures in the western High Atlas ranges, a few deep exploration wells, uplifted offshore blocks composing the Cape Verde and Canary Island groups, Legs 41, 47, 50, and 79 DSDP sites, and

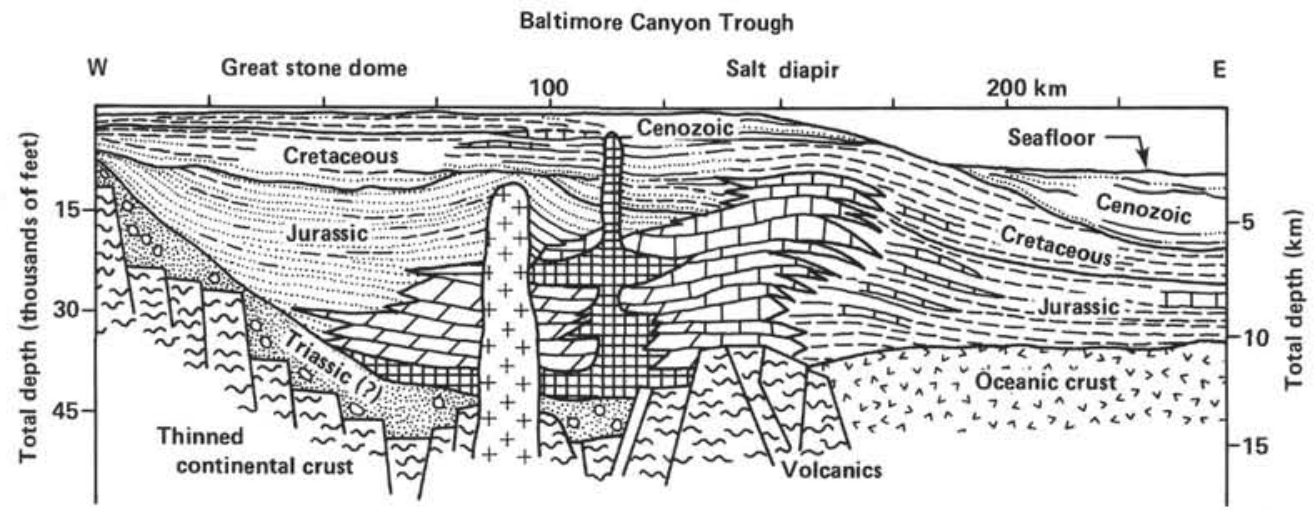

Figure 31. Schematic section through the Baltimore Canyon Trough, interpreted from the multichannel seismic reflection profiles. (Vertical exaggeration is $\times 5$.)

Florida

Platform
Blake Plateau Basin
Blake Basin

Sites 390/392 (projected)
Site 534

(projected)

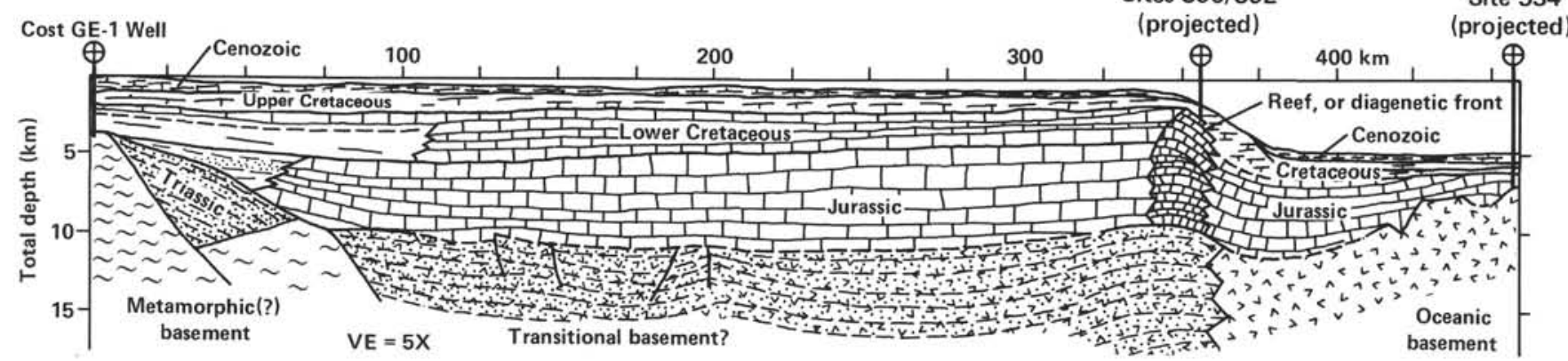

Figure 32. Schematic cross-section of the Blake Plateau Basin. 


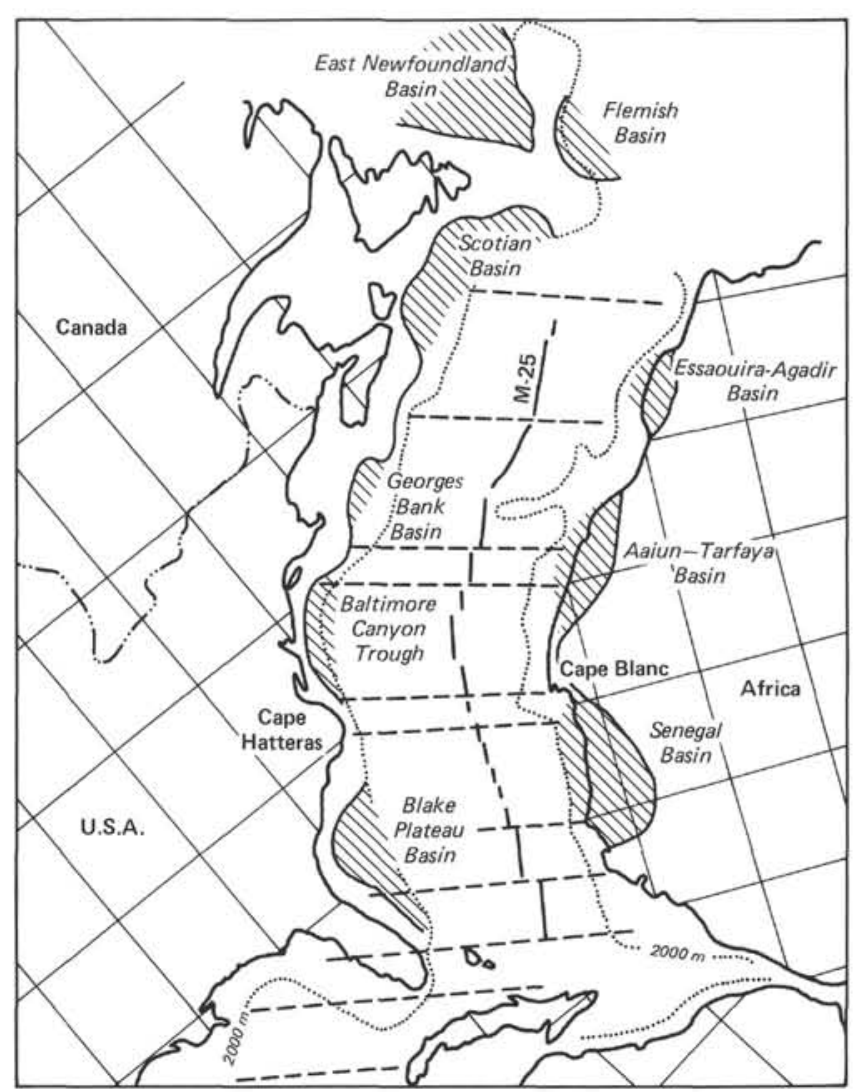

Figure 33. Sedimentary basins of the African and North American margins in their reconstructed relations at the time of Marine Magnetic Anomaly M-25 (uppermost Oxfordian).

seismic profile interpretations. Dating is generally poor; for instance, no Bajocian-Bathonian fossils have been reported in any sediments presumed to span this interval (see Lancelot and Winterer, 1980).

The brief summary of the Mesozoic history of the African margin (Fig. 34) is compiled from reviews by Jansa and Wiedmann (1982) and Lancelot and Winterer (1980). Additional data on the Cape Verde Islands and Basin is from Lancelot and Seibold (1978), Robertson and Stillman (1979a, b), and Robertson (unpublished data); on the Canary Islands and adjacent DSDP Site 397 from Arthur et al., (1979); and on the Mazagan Plateau and Escarpment from Renz et al. (1975) and E. L. Winterer (personal communication, 1982).

The late Triassic and earliest Jurassic sediments of the basins are thick sequences of red terrigeneous clastic deposits and evaporites. (The pre-Late Jurassic sediments of the Senegal Basin are not exposed and have not yet been drilled.) Volcanics occur near the top of the unit in the Atlas region.

A middle Early Jurassic (late Sinemurian-Pliensbachian?) marine transgression allowed deposition of shallow-water limestones interfingering with evaporites, terrigenous clastics, and dolomites. The faunal associations and regional correlation of these limestone units suggest that this transgression came from the north (Subboreal source) rather than being an extension of the
Tethys (Lancelot and Winterer, 1980). ${ }^{7}$ There is some mixing of Tethyan and Subboreal fauna in the late Pliensbachian.

The Toarcian through Bathonian sediments are generally poorly dated red clastic beds. In the Atlas exposures, the middle of this interval has some limestone and marl, which may reflect a brief local marine incursion within this regressive interval.

During the Middle Jurassic, a tectonic episode resulted in the uplift and gentle folding of parts of the Western High Atlas and Meseta. This episode coincided with similar regional uplifts on the opposing Scotia margin and accentuated the influx of clastics.

At the end of the Middle Jurassic, a great transgression swept into all the basins, producing the thick carbonate platforms that characterize the Late Jurassic. The transgression began in the Callovian, peaked in the Oxfordian and early Kimmeridgian, and ended in the Tithonian.

Minor regressive phases in the Essaouira-Agadir Basin are indicated by calcarenite, red clay, or evaporite beds within the early Oxfordian, early Kimmeridgian, and Tithonian. The Mazagan Plateau was a stable carbonate platform during the Oxfordian and early Kimmeridgian. The Leg 79 sites demonstrated that the relief of the margin was very irregular, with both shallow-water limestones and breccias of redeposited pelagic carbonates during the Oxfordian, followed by pelagic carbonate sedimentation during the Kimmeridgian and Tithonian. The Tarfaya-Aaiun and Senegal basins were stable shelf platforms with perhaps outer reefs during the Late Jurassic.

The uplift of the Cape Verde Islands has exposed oceanic volcanoes overlain by 180 to $350 \mathrm{~m}$ of Late Jurassic to Early Cretaceous, pelagic, homogeneous, gray laminated marly limestones with chert nodules and basal metalliferous red sediment. A similar radiolarianrich, pelagic chalk facies was recovered at nearby DSDP Site 367 , but the Late Jurassic facies is more reddish.

A late Tithonian regression terminated carbonate platform activity in all basins, and the Lower Cretaceous sediments are composed of terrigenous clastics. This emergence occurred near the Cretaceous/Jurassic boundary and is recorded by hardground and erosion surface in the Essaouira-Agadir Basin, an unconformity in the Tarfaya-Aaiun Basin, and a rapid increase in terrigenous influx in the Senegal Basin. In addition, local and regional uplifts occurred, such as the rising of salt diapirs in the Essaouira Basin and the initiation of uplift of the Atlas chain in the latest Jurassic.

The outer margin off the Mazagan Plateau appears to have a regional hiatus because the three DSDP Leg 79 sites revealed the absence of Lower Cretaceous sediments above the Jurassic. Site 416 on the oceanic crust to the southwest recovered a latest Jurassic and Early Cretaceous turbidite sequence; the ratio of carbonate to terrigenous material declines in the earliest Cretaceous

\footnotetext{
${ }^{7}$ This theory is perhaps distorted by lithologic correlations to the Rif area (L.J.).
} 


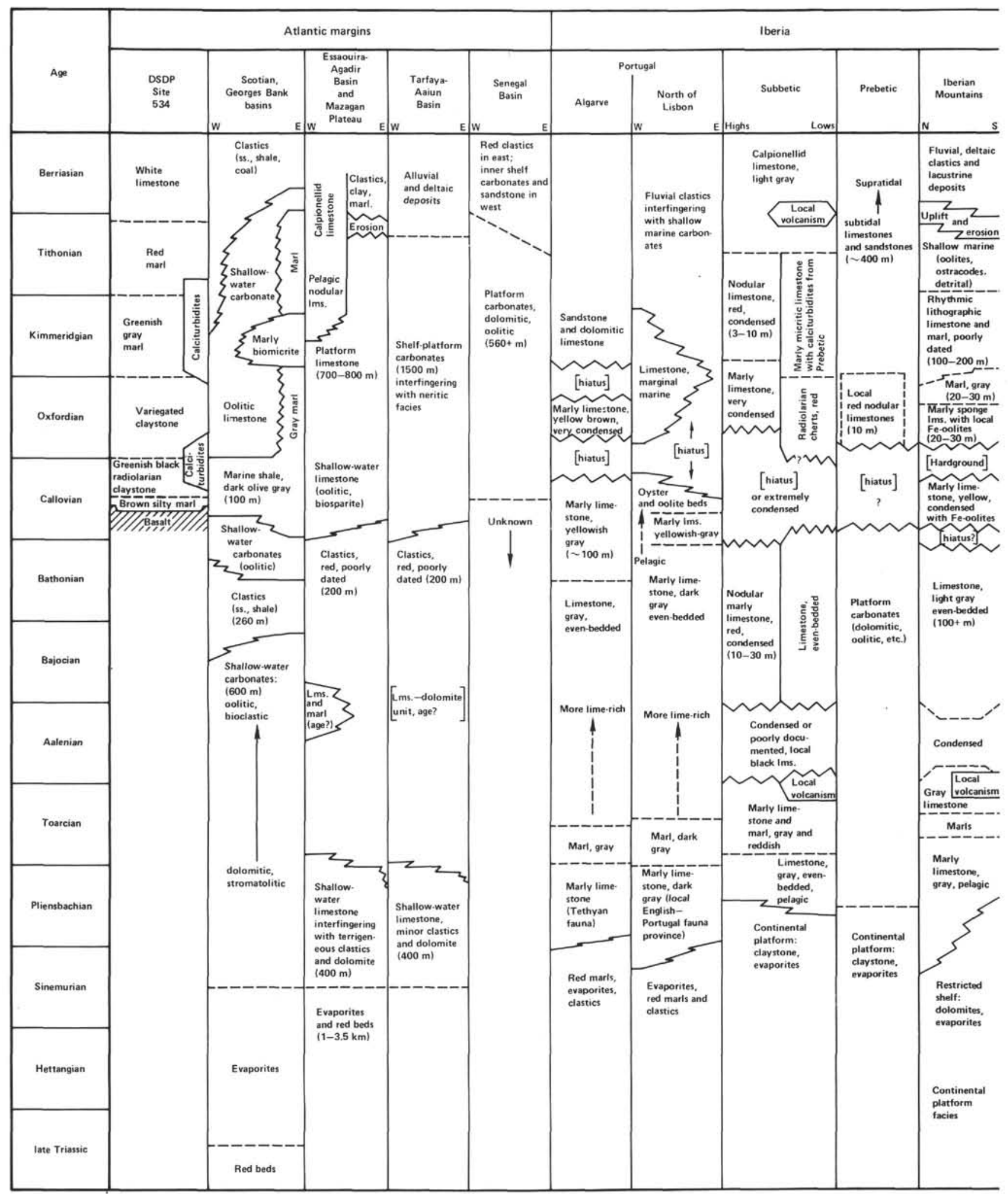

Figure 34. Generalized Jurassic stratigraphy of the Atlantic-Tethys seaway. (Data are compiled from references in the text. Most ages, especially for the boundaries of the units, are approximate; thicknesses, where given, are of a typical section; ss. = sandstone, Ims. = limestone; jagged line represents time transgressive facies; dashed line indicates an uncertain age boundary between facies.) 


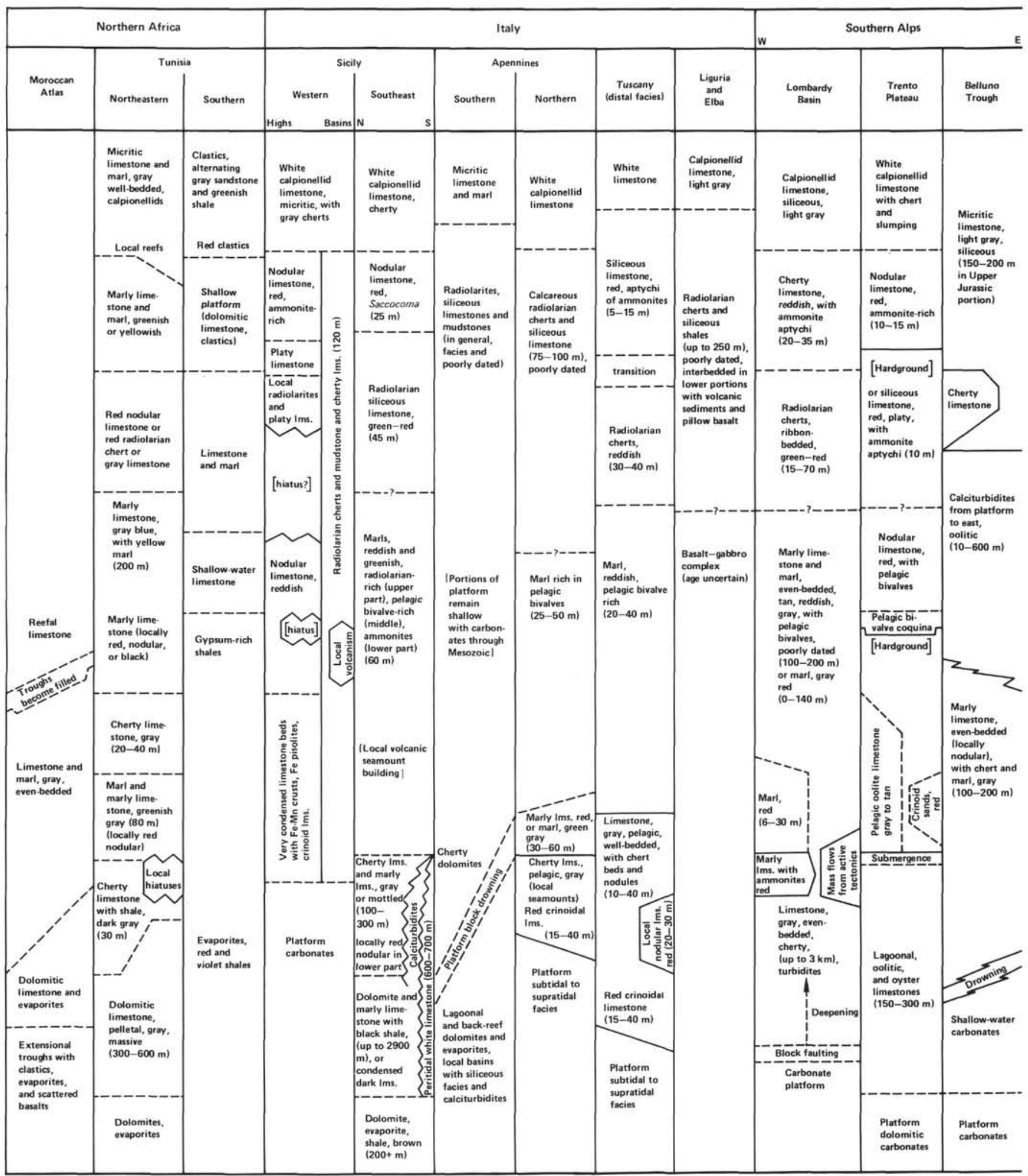

Figure 34. (Continued).

part of this sequence. A similar turbidite sequence, $1500 \mathrm{~m}$ thick, is uplifted on the nearby Canary Islands. This region has been interpreted as being a deep-sea-fan environment during the Early Cretaceous, with detrital input from the African crystalline massifs and carbonate inpuc from collapsed platforms.

\section{Summary of Jurassic Atlantic Margins}

On both sides of the Atlantic, the Jurassic sediment history of the margins is fully known only in the northern basins; the southern basins in the vicinity of Site 534 have had only the uppermost Jurassic sediments drilled. 


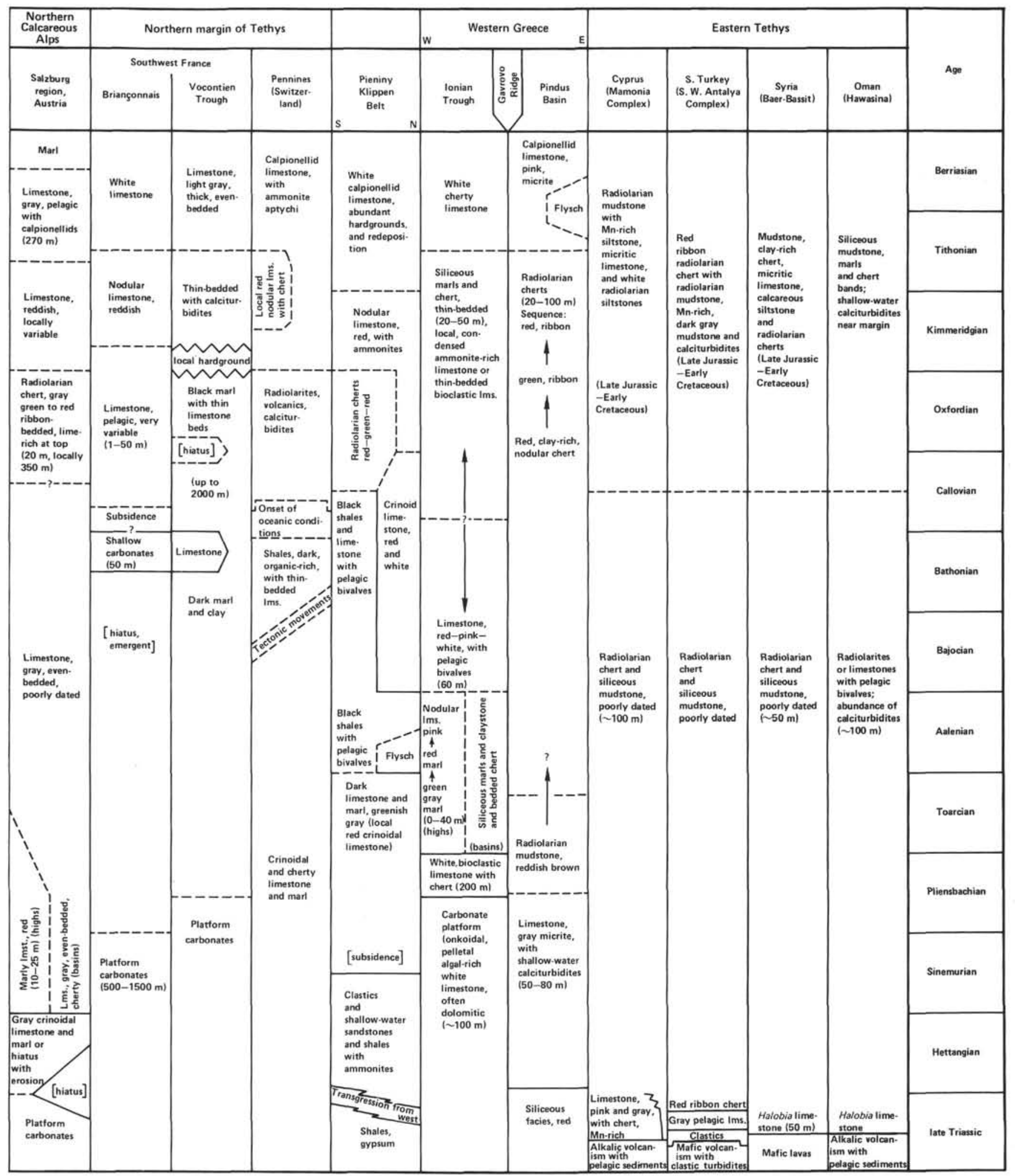

Figure 34. (Continued).

In all the basins, changes in sedimentation and relative sea level appear to be synchronous; thus we may compile a generalized history.

The late Triassic-earliest Jurassic was dominated by an arid continental environment with red-bed and evaporite deposition. Marine conditions developed in the late Sinemurian and continued through the Pliensbachian, allowing deposition of shallow-water carbonates and growth of bioherms. This marine transgression could have been caused by eustatic sea-level rise, an early phase of rifting and subsidence, or both. The sea withdrew from the margins in the early Middle Jurassic. 
Regional uplifting occurred inland of the margins, and clastic deposition dominated the Bajocian and Bathonian. A second marine transgression commenced in the Callovian, and massive carbonate platforms developed as the continental margins experienced rapid subsidence through the Oxfordian and early Kimmeridgian. Pelagic conditions developed at the outer portions of the margins. This sudden change from continental conditions to rapid subsidence and active carbonate buildups on the margins is coincident with the beginning of active seafloor spreading between the Blake Spur Ridge Anomaly and Africa. A major regression began in the late Kimmeridgian, intensified in the late Tithonian, and continued into the Early Cretaceous. Many of the carbonate platforms were exposed and/or buried under the increased influx of terrigenous detritus from the uplifting hinterlands (Avalon Uplift, Atlas region, etc.).

\section{PART THREE-JURASSIC SEDIMENTS OF THE TETHYS OCEAN}

Belts of marine and pelagic sediments and ophiolites through southern Europe, northernmost Africa, and southern Asia record the former existence of a complex system of Mesozoic ocean basins and seaways, known collectively as the Tethys. The history of the concept is reviewed by Hsü (1977) and Jenkyns (1980b). Compressional movements between Africa and Europe and between India and Asia through the Cretaceous and Tertiary resulted in the closure of Tethys and the exposure of pelagic sediments through uplift and overthrust emplacement. Generations of geologists have studied these oceanic sediments, making the sedimentation history of the Tethys the best known of any Mesozoic ocean; however, the tectonic evolution of the Tethys remains a topic for creative puzzle fitting. Part Three of this chapter presents a general summary of the Jurassic pelagic facies of the Tethys in three regions: (1) the Iberian plate and opposing North African margin; (2) the continuous southern continental margin of the Western Tethys running from northern Tunisia through Sicily, the Apennines, the Southern Alps, Austria, and into western Greece, and (3) the western portion of the Eastern Tethys preserved in Greece, Cyprus, Anatolia, and into Oman and Iran. The amazing variety of reconstructions are also briefly mentioned.

\section{Iberia and Atlas Mountains}

The Jurassic ocean basins of the Central Atlantic and Western Tethys display similar patterns of pelagic sedimentation (Bernoulli, 1972; Bernoulli and Jenkyns, 1974; Bourbon, 1978), and it is assumed that the two basins were interconnected and exchanged both surface and deep waters. This connecting seaway must have been within the North African (Atlas) and Iberian peninsula region.

Jurassic pelagic sediments occur in several areas: a series of elongate troughs in the Atlas region, the Subbetic belt across southern Spain, the Iberian Cordillera basin in central eastern Spain, small basins north of Lisbon, and the Algarve basin of southern Portugal.

\section{Sedimentation History ${ }^{8}$}

During the Triassic the margins of the Iberian meseta were broad shallow platforms that received a typical succession of red fluvial clastics ("Buntersandstein" facies), restricted carbonate banks ("Muschelkalk" facies), then lacustrine and brackish-water marls and evaporites ("Keuper" facies) with local volcanics. The extensive evaporite deposits later became shear zones for tectonic thrusts. Dolomitic limestones and associated saline facies were widespread during a gradual transgression in the earliest Jurassic.

The collapse of these carbonate platforms and onset of pelagic sedimentation of even-bedded gray limestones and marls began during the late Sinemurian on the margins and progressed inward through the Pliensbachian (Fig. 34). This facies continues through the Middle Jurassic in most of the Iberian basins and within the extensional troughs of the central High Atlas, with only minor changes in the proportions of limestone and marl (e.g., marl-rich units are characteristic of the middle Toarcian). The southern Subbetic basin became separated from the carbonate platform in the north (Prebetic) by a narrow submerged plateau and trough - a topography common to many of the Tethyan margins. Condensed reddish nodular limestones are a common facies on the relative highs within the Subbetic basin during the Middle Jurassic.

On the present northern limit of the Iberian peninsula, the basinal sediments now exposed in the Cantabria Cordillera and Bilboa synclinorium consist mainly of monotonous sequences of black shales and dark gray limestones that began in the late Triassic, continued through the Jurassic, and extended into the Cretaceous (Vandenberg, 1980).

In North Africa, many of the Liassic troughs in the Atlas had filled with sediment by the Bajocian and were capped by reefs.

Sedimentation changed dramatically in all basins in the late Bathonian. In the Subbetic, Iberian Cordillera, and central and south Portugal basins, the uppermost Bathonian is either absent, very condensed, or poorly documented.

The Callovian of Iberia is extremely condensed, except in the Portuguese basins. The southern Algarve basin has a nearly complete Callovian in a facies of yellowish gray limestone and marl, truncated by an erosional surface and a thin deposit of yellowish brown middle Oxfordian marly limestone, overlain by thick deposits of Kimmeridgian sandstones and dolomitic limestones. The central "Lusitanian" basin displays a gradual regression in the middle and upper Callovian as pelagic limestones and marls gave way to oolite marine facies during

\footnotetext{
${ }^{8}$ In order to avoid a monotonous recital of references after each statement, the main consulted publications and personal comunications for this section are: Subbetic-Prebetic: Garcia-Hernandez et al. (1980); Iberian Cordillera: G. Melendez (personal communication, 1981, 1982), A. Goy (personal communication, 1982), Ríos (1978); Portugal: R. B. da Rocha (personal communication, 1981), da Rocha (1976), da Rocha and Marques (1979), RugetPerrot (1961); and North Africa: Van Houten (1977), Van Houten and Brown (1977), Evans and Kendall (1977), Durand Delga (1967).
} 
the late Oxfordian and early Kimmeridgian, before succumbing to a continental and shallow-shelf environment.

In the Iberian Cordillera, a gradual regression is apparent as Kimmeridgian rhythmic limestones pass into shallow-shelf facies prior to a late Tithonian erosion event and deposition of fluvial and fan deposits. The underlying pelagic marly limestones of the CallovianOxfordian are commonly condensed, and an upper $\mathrm{Cal}-$ lovian-lower Oxfordian hiatus and hardground is ubiquitous.

The relative highs of the Subbetic also had a late Callovian-early Oxfordian hiatus, then condensed nodular pelagic limestone deposition continued through the rest of the Late Jurassic. The relative lows had deposition of radiolarian cherts during the Callovian-Oxfordian (poor biostratigraphic control, however), followed by marly and micritic limestones with intercalations of calciturbidites from the Prebetic platform. Marly limestones with calpionellids are the predominant facies in the Early Cretaceous. The facies in the Subbetic of the Upper Jurassic through Lower Cretaceous mirror those of the Western Tethys and North Atlantic, and this region was probably the connecting seaway.

\section{Aspects of the Tectonic History}

The Iberian peninsula was a semi-independent microplate through most of the Jurassic and Cretaceous, as evidenced by subsidence and pelagic sedimentation on all margins of the central craton. In recent years many of the anomalous aspects of its geological history have been solved, but several puzzles remain.

\section{Northern Iberian Margin}

The Iberian Cordillera basin was an extensive region of subsidence during the late Early and Middle Jurassic, then ceased to be a pelagic realm in the Late Jurassic. It may have connected to the basin or trough in the northwest, evidenced by Jurassic basin deposits in the Cantabrian chain, but this possibility cannot be documented. The Iberian Cordillera deposits represent the southern margin of a basin, which may have formed as a "failed arm" during the early rifting stage of the Western Tethys, but the northern margin counterpart has not been documented. The Pyrénées contain exposures of Lower Jurassic carbonates, but the rest of the Jurassic is apparently absent. The next active phase of rifting between Iberia and Europe was during the Barremian and Aptian (de Graciansky, Poag, et al., in press), preceding the Late Cretaceous seafloor spreading that opened the Bay of Biscay (Williams, 1975; Ries, 1978; Montadert et al., 1979). This episode was probably a direct result of the separation of Europe and North America in the Late Cretaceous.

\section{Southern Iberian Margin}

In the Jurassic phase of opening of the Atlantic Ocean, as Africa drifted eastward relative to North America, most of the relative movement between Africa and Europe was left-lateral shear (Sclater et al., 1977; LePichon et al, 1977; etc.). Because there are no apparent marine magnetic anomalies of the Early Cretace Jus-
Late Jurassic M-sequence older than M-O identified off the western coast of Portugal, Iberia must have remained attached to North America until the end of the Early Cretaceous (Sibuet and Ryan, 1979). Therefore, the dominant motion between African and Iberia during the Late Jurassic may have been along a left-lateral transform fault. However, the Early Jurassic development of the passive margin of the Subbetic-Prebetic suggests an earlier tensional phase between Africa and Iberia. Presumably, a similar passive margin developed on the opposing African continent (northern Algeria-Tunisia?).

The Betic region of southernmost Spain and the PreRif and Kabyle regions of northernmost Morocco and Algeria are allochthonous exotic terranes, which were probably emplaced sometime during the Late Cretaceous-early Tertiary interval of right-lateral movement between Iberia and Africa, prior to or contemporaneous with the late Oligocene-early Miocene compression tectonics in the Subbetics (Bourrouilh and Gorsline, 1979; Garcia-Hernandez et al., 1980). The eastern Atlas had a coeval compressive stage (Cairé, 1974; Durand Delga, 1967). The original location of the Betic block is unknown.

The Jurassic eastern margin of Iberia was disrupted by the middle Tertiary rifting of Corsica, Sardinia, the Balearic Islands, and possibly other blocks from it (Hsü, 1977).

\section{Western Tethys}

\section{The Tethyan Belt}

A fairly continuous belt of Jurassic-Early Cretaceous pelagic sediments stretches from Tunisia to the Italian Southern Alps (Fig. 35). This Mesozoic continental margin complex is interrupted by the allochthonous Calabria massif of southern Italy (Channell et al., 1979; Catalano et al., 1976), and by the Ligurian nappes and Po basin fault (Bosellini, 1973); Vandenberg and Wonders, 1976). Nappes in Liguria and Piemont contain ophiolite suites, recording Jurassic oceanic crust. Pelagic sediments of the Briançonnais region of southeastern France are on the opposite side of the ophiolite belt and therefore must have been deposited on the northern continental margin of the Tethys.

Austroalpine nappes are believed to be a continuation of the southern margin, based on the similarity of their Mesozoic facies and tectonic history (arguments also used to infer a continuation of the Austroalpine belt into the Carpathians). The situation is distorted by the apparent $90^{\circ}$-clockwise rotation of the Austroalpines with respect to the Southern Alps (Mauritsch and Frisch, 1978; Ogg and Steiner, unpublished data) and the lack of a definite northern continental margin of the Tethys in this region. Only in the southeastern corner of France and the adjacent Swiss Alps has the history of the northern margin been partially deciphered.

Jurassic pelagic sediments occur in the Carpathian and Tatra mountain regions of eastern Europe, and this belt is considered to be either a continuation of the Tethys southern margin before its bend southward through the Balkan peninsula or a northward embay- 


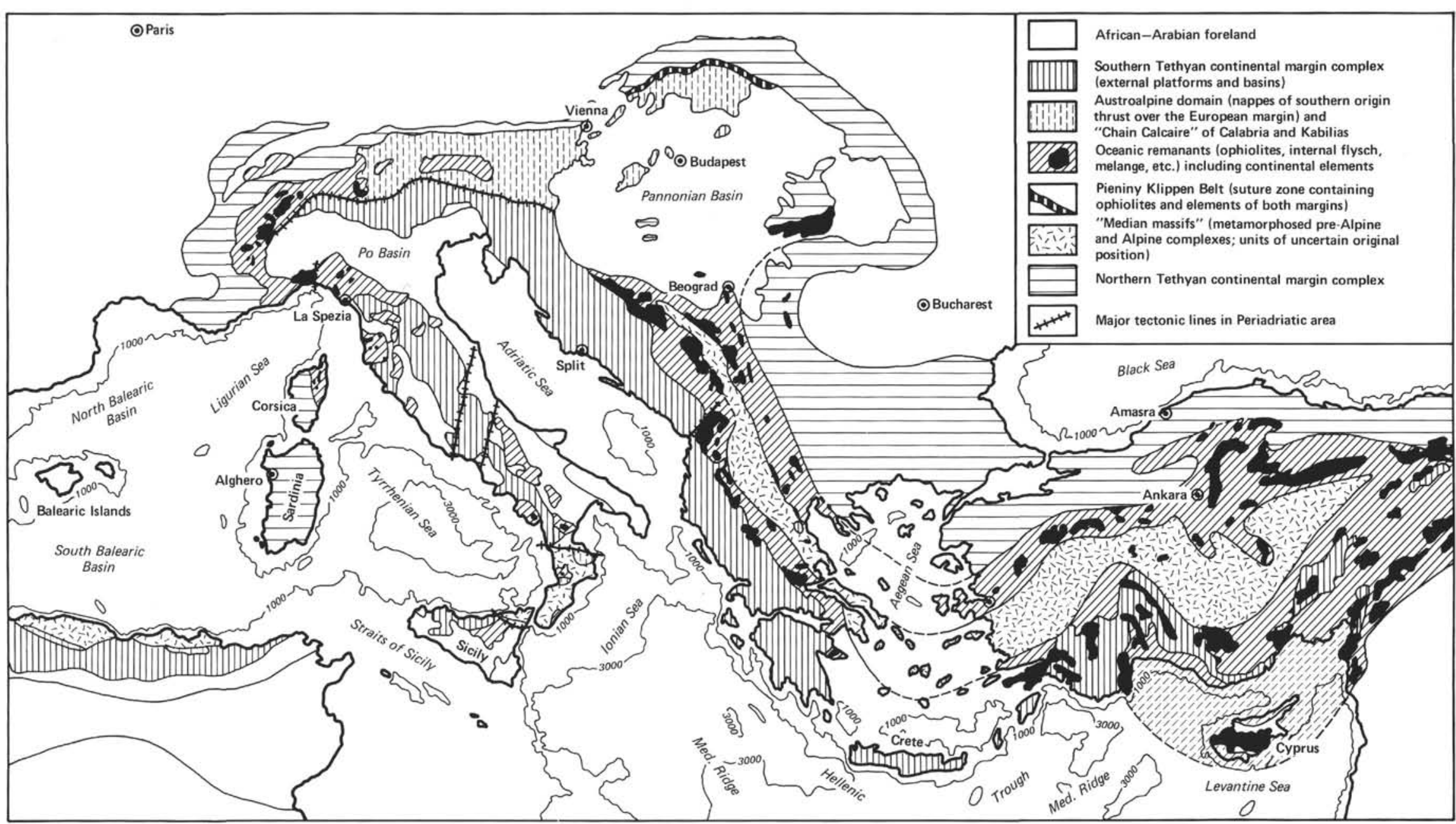

Figure 35. Main structural features of the northern Mediterranean region. Southern and northern Tethyan margins are partially interpretive. (After Channell et al., 1979). 
ment. The southern continental margin resumes its identity in the pelagic sediment-ophiolite belt running down the Yugoslavian Diranides and western Greek Hellenides mountain chains. The situation in the AegeanAnatolia region is not fully understood.

\section{Sedimentation History ${ }^{9}$}

An extensive carbonate platform was the main feature of the western Tethys from the middle Triassic until the middle of the Liassic. Reefal, oolitic, and lagoonal carbonates with local evaporite, clastic, and coal deposits are ubiquitous (Fig. 34). Only a few local basins or troughs accumulated deep-water sediments during this interval (e.g., Lagonegro basin in southern Italy, Hallstatt facies in Austria, Pindos trough in Greece, and others). A middle Triassic rifting episode was followed by subsidence and a generally quiet tectonic environment. The main phase of rifting during the Early Jurassic resulted in widespread drowning of the carbonate platforms and initiation of pelagic sedimentation on the block-faulted passive margin. It appears that another interval of tectonic quiescence followed before the initiation of active seafloor spreading in the Middle Jurassic.

There seems to be a general age progression of the Early Jurassic collapse of the carbonate platform from early Hettangian in Austria and the Southern Alps, late Hettangian in Tuscany, Sinemurian in the northern Apennines, to late Pliensbachian in Sicily and Tunisia. Other subsidence pulses followed this initial collapse. Further block-fault activity widened the margin, and the formation of an inner trough (Ionian Zone, Belluno Trough, Umbria basin, etc.) occurred at a slightly later stage than the formation of the main outer basin of the margin. The block faulting created a very irregular topography; local ridges, broad plateaus, and "seamounts" remained emergent or as active carbonate banks for long periods after the initial episodes of rifting. There is no sign of Early Jurassic rifting activity affecting the future northern margin of the Tethys (Trumpy, 1975), indeed the Briançonnais region was uplifted and remained emergent until the late Bathonian.

On the submerged topographic highs of the southern margin, the earliest sediments are commonly red, crinoidal, bioclastic limestones or $\mathrm{Fe}-\mathrm{Mn}$ crusts overlain by condensed red marly limestone. The basin or trough deposits are typically thick deposits of even-bedded gray biomicrite limestone, with nodules and bands of replacement chert and interbedded marls and calcareous turbi-

\footnotetext{
${ }^{9}$ Our summary of the sedimentation history of this southern continental margin and fragments of the northern margin is compiled from the following selection of regional reviews - general: Sander (1970), Arkell (1956), Bernoulli and Jenkyns (1974), Hsui (1976); Tunisia: Bismuth et al. (1967), Busson (1967), Bonnefous (1967), Burollet (1967), Burollet et al. (1978), Salaj (1978); Sicily: Jenkyns (1970, 1971, personal communication, 1979), Patacca et al. (1979); Apennines and Tuscany: Bernoulli et al. (1979), Kälin et al. (1979), Channell et al. (1979); Briançonnais, Piemont, Vocontien Basin, and Liguria: Trumpy (1975), M. Moullade (personal communication, 1982), Cotillon (1971; personal communication, 1980). Bourbon $(1978,1980)$, Bourbon et al (1975), Bourbon et al (1976); Southern Alps: G980), (1975), Ogg (1981a), Winterer and Bosellini (1981), Kallin and Troestani (1967), Gas lam (1967), Garrison and Fischer (1969), Garrison (1967), Diersche (1980). Carpathians: Birkenmajer $(1960,1973)$, Wieczorek (personal communication, 1979); Yugoslavia and western Greece: Bernoulli and Renz (1970), Bernoulli and Laubscher (1972), Baltuck (1981, 1982), Cairé (1975).
}

dites. Synsedimentary slumping, debris flows, and redeposited pelagic sediments occur frequently in the basin and slope deposits, and these probably reflect the continuing rifting and block faulting (Bernoulli, 1971).

As the continental margins continued subsiding through the Middle Jurassic, many regions became deeper than the aragonite compensation depth; hence there are no preserved ammonites in these regions. This factor, plus the lack of diagnostic microfossils and nannofossils, prevents the assignment of precise ages to most of the pelagic sediments, especially in the late Bathonian-Callovian-Oxfordian, which is unfortunately the interval of particular interest at Site 534. Where ammonites are present, hiatuses in the middle-late Bajocian and late Callovian-early Oxfordian are very widespread, and the commonly assumed continuity of undated basin or plateau sediments through the Middle Jurassic is therefore suspect.

The Middle Jurassic calcareous sediments are generally characterized by the presence of small pelagic bivalves called Posidonia or Bositra, and upper Kimmeridgian-Tithonian sediments commonly have fine, sandsized fragments of Saccocoma, a pelagic crinoid. The concentration of these bioclasts in solution zones during later diagenesis can lead to a texture of carbonate-rich nodules surrounded by bioclast- and clay-rich coarse marl; this is one of many mechanisms of nodular limestone formation $(\mathrm{Ogg}, 1979,1981 \mathrm{~b})$. The Callovian and Oxfordian sediments are characterized by the abundance of radiolarians, and the late Tithonian and Berriasian limestones are rich in calpionellids.

Radiolarian cherts are the main sediment throughout the Tethys during the ?Callovian-Oxfordian. The lack of ammonites in the underlying and overlying sediments prevents accurate determination of the age span of this episode of radiolarite formation, and probably the bedded cherts extend through the Callovian in many localities (P. Baumgartner, personal communication, 1981). The progressive disappearance of aragonite ammonite shells during the Middle Jurassic, then the disappearance of calcareous material, followed by the reappearance of siliceous limestones with calcite aptychi of ammonites during the Kimmeridgian has been explained by Winterer and Bosellini (1981) as having been caused by the steady subsidence of margin blocks through aragonite and carbonate dissolution levels during the Middle Jurassic and Oxfordian, then a sharp drop of the ACD and CCD during the Kimmeridgian. They also suggest that a rise in the ACD and CCD caused by the Callovian-Oxfordian eustatic rise in sea level may be involved. There are several instances of ammonite-rich late Kimmeridgian-early Tithonian limestones overlain by ammonite-poor limestones, which suggests that the aragonite dissolution level rose in the middle Tithonian; however, there is no evidence of an accompanying CCD rise.

The abundance of cherts and siliceous limestones during the ?Callovian-Oxfordian indicates a much higher deposition rate of silica. Probably this was caused by increased radiolarian productivity of the surface waters (Hsü, 1976; Jenkyns and Winterer, 1982). Hsü (1976) suggested that silica removal by radiolarians eventual- 
ly depleted the silica "nutrient" of the semirestricted Western Tethys, allowing calcareous nannoplankton to become competitive; Diersche (1980) proposed that the silica input to the Western Tethys was enhanced in the Oxfordian by increased river influx and submarine volcanism. Another possibility is that high radiolarian productivity is a common oceanographic condition in deep, semirestricted, embryonic oceans or basins (Jenkyns and Winterer, 1982), and the end of chert deposition in the Kimmeridgian is due mainly to dilution of the radiolarians by carbonate. The abundance of replaced radiolarians in the Tithonian-Berriasian cherty biomicrite limestones, which had a higher net sedimentation rate, supports this interpretation.

The virtual absence of any middle and late Callovian and early Oxfordian pelagic sediments is puzzling. In nearly every pelagic sedimentary section for which precise ammonite-dating is available, this interval is an hiatus, and in sections with poorer biostratigraphy, the presence of this interval can rarely be proven. The absence or condensed character of upper Callovian-lower Oxfordian sediments is also extensive beyond the Tethys realm, for example, Swabia (A. Hallam, personal communication, 1982). Only in the rapidly accumulating marls of the relatively shallow basins in France has a complete Callovian sequence been identified. A middle to late Bajocian hiatus is less common (or else less documented). Vail and Todd (1980) correlate the middle Oxfordian hiatuses in the North Sea to two episodes of rapid coastal onlap. Perhaps the effects of Callovian and early Oxfordian global eustatic sea level rises overlapped in the Western Tethys. Where middle Callovian to early Oxfordian sediments are present (black or brownish gray marls in southeastern France dated by ammonites, green cherts in Lombardy dated by radiolarians), they generally indicate reducing conditions. Hallam and Bradshaw (1979) show that organic-rich deep-water Jurassic deposits correlate with major transgressions; they cite the middle Callovian "Lower Oxfordian Clay" as an example. Hallam (1978) infers a late Callovian regression event, which may have led to the partial absence of marginal sediments of that age. Hence it appears that pelagic sediments of the Western Tethys (and Atlantic) in the middle Callovian through early Oxfordian are either absent or reflect reducing conditions.

The upper Oxfordian-Kimmeridgian-lower Tithonian sediments are generally red and show a progressive increase in carbonate content. In the Late Tithonian, both basins and submerged plateaus received white or light gray calpionellid-rich limestones. Despite the proliferation of regional formation names (Maiolica, Biancone, Lattimosa, Calcari a Calpionelle, Oberalm Beds, Vigla, etc.), this limestone is essentially a single, widespread formation. In most areas, the sedimentation rate of the white calpionellid limestone is much greater than the underlying red sediment facies, therefore an increased influx and/or preservation of carbonate in the pelagic sediments is indicated. Possible contributing factors will be discussed later. The initiation of deposition of the white calpionellid limestone is also the apparent time of closure of the Vardar seaway (connecting the Western and the Eastern Tethys), and there is no corresponding episode of limestone deposition recorded in the Eastern Tethys.

\section{Aspects of the Tectonic History}

There are only a few constraints on the plate motions involved in the Jurassic opening of the Western Tethys, though validity of these is disputed. Reconstruction of the Jurassic seaway is difficult due to the extensive postJurassic deformation and displacement of microplates and the rotation of the major plates.

Paleomagnetic research in Italy has demonstrated that the African and Italian Mesozoic polar wander curves are very similar and that Italy has had about $50^{\circ}$-counterclockwise rotation with respect to Europe since the Triassic (Lowrie and Alvarez, 1975). Whether any relative rotation of Italy and Africa during the Tertiary has occurred or not is disputed (Vandenberg [1979a, b] and Channell et al. [1979], respectively). The Austrian margin has had a $90^{\circ}$-clockwise rotation relative to northern Italy since the Middle Jurassic (Mauritsch and Frisch, 1978, 1980), and the Sicilian nappes have undergone a similar degree of relative clockwise rotation (Channell et al., 1980). The reconstruction of the Tunisia-Sicily-Italy margin of the Tethys is further complicated by postJurassic major transverse faults, nappe foreshortening, and microplate collisions.

The relative motion of Africa and Europe is constrained by the spreading history of the Atlantic as interpreted from magnetic anomalies and transform faults (Pitman and Talwani, 1972; Biju-Duval et al., 1977; Le Pichon et al., 1977; Sclater et al., 1977). However, the timing of events, initial fit, and direction of spreading during the Jurassic Magnetic Quiet Zone is not yet entirely known. The initiation of active seafloor spreading in the Atlantic (=Bathonian?) should be equivalent in age to the initiation of opening of the Western Tethys off the Italian margin, if the Italy-Greece plate was attached to Africa through the Mesozoic. If the Italy-Greece region is considered to be an independent plate from Africa during the Jurassic, then very different spreading histories can be proposed (e.g., Dewey et al., 1973; Laubscher and Bernoulli, 1977; Biju-Duval et al., 1977). Most of these reconstructions incorporate a seaway between Sicily and Italy during part of the Mesozoic, which has not yet been documented by geological evidence.

The lack of a definite northern Tethys margin opposite the Austria-Yugoslavia-Greece margin is usually ignored; indeed in most reconstructions an open ocean off this margin is indicated from the Triassic onward, which makes it very difficult to explain the Early Jurassic rifting-subsiding episode of this portion of the southern margin. The present fit of the Yugoslavia-Greece margin against the eastern Balkan-Turkey block has been explained variously by a late-stage movement of that block to the west (Vandenberg, 1979a), by assuming that Turkey-Anatolia is a continuation of the ItalyGreece plate (Sengör and Yilmaz, 1981), by a geometrically fortunate collision (Biju-Duval et al., 1977), or by combinations of these possibilities. 
From this inadequate review, it is apparent that the puzzle of the Jurassic and post-Jurassic tectonic history of the Western Tethys is far from solved.

\section{Eastern Tethys}

Between the Western Tethys seaway and the Mesozoic Pacific Ocean was a poorly understood series of rifts and small ocean basins. This connecting seaway (or multiple seaways) is evidenced by scattered exposures of Mesozoic pelagic sediments and ophiolite assemblages in eastern Greece, Turkey, Cyprus, northern Syria, Oman, and western Iran. Post-Jurassic subduction, collision, shear, and other tectonic activity on local, regional and continental scales have severely distorted the original relationships of different nappes within each exposure and the original location of each exposure relative to the others. As a consequence, the evolution and the sedimentation history of the Eastern Tethys (or "NeoTethys") are poorly known and are the subjects of considerable controversy. In this section, we attempt to summarize the geological history of the Eastern Tethys and some of the models of tectonic evolution. ${ }^{10}$ Generalized stratigraphic sections are shown in Figure 34.

During the middle Triassic through Early Jurassic, the "Paleo-Tethys," a large wedge-shaped embayment of the "Pacific" shown on reconstructions of the Pangea supercontinent (e.g., Smith et al., 1973) was apparently being closed with a subduction zone dipping beneath present-day northern Turkey (see Sengör and Yilmaz, 1981). A series of deformation and tectonic episodes during the Early and Middle Jurassic in the circum-Black Sea region (these are collectively labelled as the Cimmerian orogeny in the older literature) indicate the final closure and associated continent and island-arc collisions. To the south of the subduction zone, crustal extension with associated alkalic volcanism, block faulting, transgression, and construction of carbonate buildups occurred in one or more rift zones, and marginal seas and possibly microplates were created. Rifting activity was most pronounced during the middle and late Triassic, but in Oman there is evidence of Permian rifting. The first definite record of oceanic crust in the preserved record is not until Late Jurassic or Early Cretaceous, when true ophiolites appeared, but there may have been some transitional oceanic crust similar to the Red Sea situation today.

The upper Triassic (especially Carnian) mafic lavas are overlain by gray to pink Halobia, and/or ammonitebearing micritic limestone, red-ribbon radiolarian cherts, ferruginous and manganiferous sediments, redeposited carbonates, and minor quartzose clastics. The eastern

\footnotetext{
${ }^{10}$ This account is compiled from the following selected sources and review articlesgeneral: Brunn (1976), Laubscher and Bernoulli (1977), Robertson and Woodcock (1980), Rocci et al. (1980), Sengör and Yilmaz (1981), Jenkyns (1980b); Cyprus: Ealey and Knox (1975), Lapierre (1975), Lapierre and Rocci (1976), Robertson and Woodcock (1979), Swarbrick (1980), Swarbrick and Robertson (1980); Turkey: Dumont et al. (1972), Juteau (1975), Marcoux (1970, 1974, 1976), Poisson (1978), Ricou et al. (1974), Robertson and Woodcock (1981a, b, c), Waldron (1981); Syria: Delaune-Mayer (1978), Delaune-Mayer and Parrot (1976), Delaune-Mayer et al., 1977), Delaune-Mayer and Saint-Marc (in press), Parrot (1974), A. H. F, Robertson and N. H. Woodcock (personal communication, 1982); Oman, Zagros Mountains: Colsman (1981). Glennie et (1973, 1974), Oman, Zagros (1981), (1981), Scarle et al. (1980), Woodcock and Robetson (1982); Creece (esp. Othris: Aubouin et al. (1970), Barton (1976), Baumgartner and Bernoulli (1976), Hynes et al. (1972), Price (1977), Smith et al. (1975).
}

Mediterranean and Oman exposures indicate that intensive tectonic and volcanic activity had ceased by latest Triassic. The Early and Middle Jurassic is characterized by subsidence and the accumulation of poorly dated siliceous facies.

The absence of any preserved Jurassic oceanic crust or ophiolites or of any profound subsidence of the adjacent carbonate margins (in contrast to the Atlantic or Western Tethys margins) suggests that there was no major seafloor spreading throughout much or all of the Jurassic (Robertson and Woodcock, 1980). Sengör and Yilmaz (1981), faced with the geometric dilemma of closing the wide Paleo-Tethys to the north of Anatolia in their reconstructions, have postulated that there was major seafloor spreading in the newly created Eastern Tethys (which did not leave a recognizable record) and that two wide seaways were created-a northern branch that connected with the "Vardar Ocean" of Greece (and presumably with the Western Tethys seaway of ItalyAustria) and a southern branch associated with the southern Turkey and Cyprus exposures and of which the eastern Mediterranean is a remnant. Robertson and Woodcock (1980) proposed that this southern portion of the Eastern Tethys did not undergo active seafloor spreading until the mid-Cretaceous; they did not examine a possible northern branch.

In contrast to the Western Tethys, radiolarian cherts and siliceous mudstones dominate the Eastern Tethys Lower and Middle Jurassic basinal sequences that have been investigated. In Oman, in the Mamonia Complex (Cyprus), and in the Antalya Complex (southern Turkey), the poorly dated siliceous facies overlie mafic lavas of the late Triassic rift phase. During this time, substantial carbonate platforms were constructed along the rifted margins (e.g., Sahtan Group, Oman) with formations of adjacent submarine fans (e.g., in the Guwayza Formation and Wahrah Formation, Oman, and the Yenicebogazi Dere Formation, Antalya Complex). The lack of preserved pelagic carbonate facies between the carbonate platforms and the basins with siliceous sediments suggests that a very shallow CCD existed within this narrow-restricted southern part of the Eastern Tethys.

Upper Jurassic to Lower Cretaceous basinal facies are more diverse and better dated than older pelagic sequences. In the autochthonous Sumeini Group and the allochthonous Hawasina, the basin edge and basinal facies of this age are similar, but more siliceous, and contain intercalations of shallow-water-derived calcareous turbidites. The poorly dated Jurassic sediments of BaërBassit (Syria) are chiefly mudstones, argillaceous cherts, micritic limestones with radiolarians, and calcareous silts. In the Antalya Complex (southern Turkey), basinal facies comprise red-ribbon radiolarian cherts intercalated with radiolarian mudstones and local lenses of black or dark gray manganiferous mudstone and pyrolusite ore. Proximal sequences include thin silicified calcareous turbidites and quartzose siltstones. In the Mamonia Complex (Cyprus), the more distal basinal sequence (Mavrokolymbos Formation of the Dhiarizos Group) consists of thin-bedded radiolarian mudstones, manga- 
niferous siltstones, calcilutites, and white radiolarian siltstones. Similar facies in the more proximal sequence (Episkopi Formation of the Ayios Photios Group) include intercalations of orange orthoquartzites, locally with black shale horizons containing Early Cretaceous plant spores. In Greece, the basinal facies are mainly poorly dated radiolarian mudstones and cherts and occurrences of ophiolotic detritus and redeposited limestones. The Othris ophiolite is considered to have been formed by seafloor spreading during the early Middle Jurassic.

In the Upper Jurassic-Lower Cretaceous basinal sequences of the southern and eastern portions of the Eastern Tethys, tholeiitic lavas occur within the Antalya Complex (Waldron, 1981), and manganiferous sediments signifying active adjacent volcanism (Robertson, 1981) are found within the southwest Antalya Complex area and in Oman and Cyprus. The formation of the ophiolite complexes of the Semail Nappe (Oman), Hatay (Turkey), Tekirova (Antalya Complex, Turkey), and Troodos (Cyprus) occurred during a middle to Late Cretaceous pulse of ocean floor spreading. Unlike other regions, a major phase of ophiolite emplacement occurred in Greece at the end of the Jurassic, indicating closure of this end of the northern branch of the Eastern Tethys.

The ubiquitous upper Tithonian-Lower Cretaceous white pelagic limestones of the Atlantic Western Tethys seaway is a feature totally absent in the Eastern Tethys; likewise a drop in the CCD during the KimmeridgianTithonian is not observed in the Eastern Tethys. Pelagic chalks overlie the radiolarian cherts locally in the Mamonia Complex (Cyprus), in the Antalya Complex (southern Turkey) and in the northern Oman Mountains, but this transition appears to be middle to Late Cretaceous.

In summary, the pelagic sedimentation history of the Eastern Tethys, as preserved in the few exposures, indicates that sedimentation was predominantly siliceous in all basins throughout the Jurassic and Early Cretaceous. The CCD must have remained at fairly shallow depths, and the available record does not allow identification of any significant regional changes in pelagic sedimentation. The Eastern and Western Tethys were effectively two distinct, uncoupled oceanographic regions (except perhaps in the Callovian-Oxfordian episode of siliceous sedimentation in the Western Tethys). This relationship is in sharp contrast to the coupled Atlantic-Western Tethys seaway.

\section{PART FOUR-SYNTHESIS: SITE 534 IN THE CONTEXT OF THE JURASSIC ATLANTIC-TETHYS OCEAN}

The sedimentation history of any DSDP site is a complex integration and interaction of a variety of global, basin, and local factors. The effects of global eustatic changes in sea level on continental margins partially govern the input of terrestrial clastics and/or debris from carbonate platforms and change the carbonate dissolution levels. Climatic conditions are reflected in the amount and composition of terrestrial detritus and or- ganic material. The configuration of the basin affects patterns of circulation, fertility, and interchange with other basins. Local influences include subsidence of the basement, the distance to the active spreading ridge and continental margins, and seafloor topography. In this final section we try to show how Site 534 fits into the larger picture of the Jurassic oceans and the AtlanticTethys basins and to describe what the Site tells us about the early sedimentation history of the Atlantic.

\section{Global Influences}

\section{Middle and Late Jurassic Eustatic Sea Level}

\section{Eustatic Sea Level Compilations}

Two independent methods of estimating the relative changes of sea level with time are: (1) determining the areal extent of marine facies on the continents and (2) identifying regressive or transgressive features on seismic reflection profiles of continental margins. Each requires compilation of vast amounts of worldwide data and must solve the problems of age control and of filtering out local anomalies. Hallam $(1975,1978)$ has summarized the current knowledge of Jurassic transgressions and regressions on the continents; however, his tentative eustatic curve is weighted heavily by the detailed research in northwest Europe and may have more brief excursions than can be supported by reliable intercontinental correlations. The more important events can be correlated beyond Europe. The seismic profile method is summarized by Vail et al. (1977), and a recent Jurassic global eustatic sea-level curve estimated from relative changes of coastal onlap is presented by Vail and Todd (1980). Unfortunately, the source data and age control have not been revealed. The two curves agree in the large-scale trends, but often do not match in the short-term fluctuations.

The early and middle Callovian (plus late Bathonian, according to Hallam) was dominated by a major rise in eustatic sea level. After a late Callovian plateau or short regression, another smaller rise occurred during the early and middle Oxfordian. Vail indicates an early Kimmeridgian transgression, followed by a rapidly oscillating sea level during the Tithonian, then a gradual regression in the Berriasian. Hallam suggests that the importance of the Kimmeridgian is overestimated and that the late Kimmeridgian-Tithonian was an interval of a long regression.

\section{Effects of Relative Sea Level}

On continental margins dominated by deposition of clastics, a relative change in sea level causes a shift in the axis of deposition and in patterns of onlap, sediment bypass (hiatus), or downlap deposition (Vail et al., 1977; Pitman, 1978). Major global unconformities on margins are correlated to rapid falls of eustatic sea level and have no direct relation to orogenic events (Vail and Todd, 1980). However, trapping of clastic input on the margins due to rapid rises of sea level can be a cause of marine hiatuses (Vail et al., 1980), though many other 
oceanographic factors, especially changes in bottomwater flow, can also cause marine hiatuses independent of sea level changes.

The response of carbonate shelves is different (reviewed by Kendall and Schlager, 1981). Relative rises in sea level spark the growth of carbonate platforms, especially the rims. When the sea level rise is slow and productivity of the carbonate platforms is high, unconsolidated aragonite mud and coarse carbonate sand are rapidly deposited and form calcareous turbidites in the adjacent basins (Schlager and Ginsburg, 1981). Other turbidites are generated off the steepened outer slope. However, rapid rises of sea level can momentarily overwhelm the growth of the platform, resulting in an hiatus or a horizon of pelagic sediment before the carbonate platform can "start-up" after a time delay. (Calcareous turbidites can also be generated during a stable sea level, if the platform builds outward from overproduction.) Relative drops in sea level expose the carbonate banks; fresh-water diagenesis rapidly cements the carbonates; and clastic sediments can be deposited across the shelf to form terrigenous turbidites in the basin. Thus for a basin near a carbonate-platform-rimmed continental margin, as is Site 534, influx of terrigenous clastics will be greatest during relative falls or low stands of sea level, whereas calcareous turbidites will be important only during high or stable stands or relative rises of sea level.

Organic-rich shale deposits on shelves appear to correlate with the initial phases of marine transgressions during the Jurassic (Hallam and Bradshaw, 1979). Jenkyns (1980a) proposed that the widespread flooding of the shelves stimulated production of nearshore marine plankton, and bacterial decomposition of this organic material produced oxygen-depleted waters at depth. A secondary effect would be the transport of large amounts of plant debris seaward, both from the swamping of vast areas of land and the increased organic productivity under the more temperature climate associated with high stands of sea level. Conversely, one might expect oxygenated waters to be more common during relative falls of sea level.

As simple mass distribution relations imply, when carbonate platforms become active centers for carbonate deposition during relative sea level rises and high stands, the compensation depth for carbonate in the oceans must rise (all other factors being equal) (Berger and Winterer, 1974; Sclater et al., 1979). The CCD and ACD should descend to greater depths during regressions and low stands of sea level.

\section{Jurassic Sea Level Influence on Site 534 and the Atlantic-Tethys Seaway}

We believe that changes in relative sea level on the margins of the early Atlantic-Tethys ocean were the dominant causes in determining the sequences of facies observed at Site 534 .

The basal unit of Site 534 is reddish brown marl overlain by organic-rich silty clay. This relative rise in the $\mathrm{CCD}$ and introduction of abundant organic matter were probably by-products of the great Callovian transgression (middle or early Callovian initiation). As sea level rose, the carbonate platform of the Blake Plateau became an active source of calcareous turbidites, which in the late Callovian had filled the trough behind the Blake Spur Ridge. The first carbonate turbidite episode of bioclastic pelmicrites at Site 534 appears to be the distal and last phase of this input from the active platform, although shallow-water debris was not recognized. The foraminifer assemblage is indicative of an outer shelf source. Deposition of organic-rich clay and influx of turbidites continued into the early Oxfordian. The termination of the calcareous turbidites was perhaps caused by a regressive excursion in the latest Callovian-early Oxfordian, which cemented the platform carbonates. Hallam (1978) shows two brief episodes of this type; Vail and Todd (1980) postulate a brief basal Oxfordian regression.

As discussed in Part Three of this paper, the elevated CCD during the middle Callovian through Oxfordian allowed the formation of the extensive radiolarian chert beds of the Western Tethys. Evidence of poorly oxygenated bottom waters or influx of large amounts of organic matter is less widespread, but is indicated by green radiolarian cherts in Lombardy (dated as early to middle Callovian, P. Baumgartner, personal communication, 1981), the Oxford clay of southern England, and the "Terres Noires" formation of south-eastern France. The marine hiatus associated with this major transgression is probably the widespread middle Callovian-early Oxfordian hiatus of the pelagic sequences of the Western Tethys. A possible hiatus at Site 534 near the Callovian/Oxfordian boundary is suggested by the sudden change in facies between the greenish black silty claystone and the variegated claystone.

On the more northern margins of the Atlantic, the Callovian transgression caused temporary drowning of portions of the carbonate platform, for example, the Callovian shaly pelagic Misaine Member of the Scotia Shelf. A minor regression in the early Oxfordian allowed the carbonate platform to recover.

The early Kimmeridgian transgression probably restimulated activity on the carbonate platforms, leading to the second episode of carbonate turbidites at Site 534 . These coarse bioclastic pelletal turbidites are from a shallow-water source environment. The Kimmeridgian transgression was probably only of regional significance, such as on the subsiding margins of the Atlantic, and Hallam's (1978) conclusion that the maximum eustatic sea level of the Jurassic was in the Oxfordian is probably correct. This interpretation is supported by the gradual dropping of the CCD during the late Oxfordian and Kimmeridgian at Site 534, suggesting a relative global reduction of carbonate sedimentation on the shelves, and by the abundance of red sediments throughout the Atlantic and Tethys, implying an end to the oxygendepleted conditions associated with transgression. The long-lived episode of bioclast-poor micrite pelagic turbidites from the late Oxfordian to earliest Tithonian perhaps reflects the increased pelagic carbonate deposition on the deeper slopes.

The drop in the ACD and CCD through the late Oxfordian and Kimmeridgian is evidenced in the Western 
Tethys by the widespread transitions from radiolarian cherts, to siliceous limestones, to limestones with chert nodules. On topographic highs (Sicily, Southern Alps), deposition of ammonite-rich sediments became possible in the Kimmeridgian. At Site 534, aragonite was identified in scattered beds between Cores 104 and 95 of the late Kimmeridgian to the early Tithonian.

The pace of the Late Jurassic general regression quickened in the Tithonian. Carbonate platforms were exposed on several parts of the Atlantic margins and covered by deltaic or alluvial deposits. The carbonate platforms of the Bahamas and Blake Plateau appear to have continued through this Tithonian-Berriasian regression, perhaps owing to a faster rate of subsidence; however, a Tithonian hiatus cannot be ruled out. In the Western Tethys, terrestrial clastic deposition replaced carbonate sedimentation in Iberia (except the Subbetic) and southern Tunisia. The bulk of carbonate deposition during the late Tithonian-Early Cretaceous low stand of sea level was in the deep sea, as evidenced by the ubiquitous white micritic limestone (Blake-Bahama Formation, Maiolica, etc).

\section{Climate}

It is beyond the scope of this paper to attempt a compilation of data on Jurassic climates. The assemblage of clay minerals and other clastics in the Jurassic sediments of Site 534 has been interpreted by Chamley et al. (this volume). They conclude that the exposed land masses of the region had a predominantly warm climate, with fairly dry or seasonally humid conditions throughout the Late Jurassic and Early Cretaceous. The relative abundance of kaolinite in the basal unit reflects more humid conditions, which correspond to the interval of the influx of abundant terrestrial organic matter. However, interpretation of climate from clay mineralogy is very model-dependent and controversial.

\section{Basin Influences}

\section{Configuration of Atlantic-Tethys Seaway}

Paleomagnetic and geologic evidence indicate a complex multistage rifting and spreading history of the Atlantic-Tethys seaway during the Triassic-Jurassic.

Possibly one of the most important recent developments relating to the early history of the Atlantic and Tethys is the identification of extensive right-lateral shear between Africa and North America-Europe in the middle Mesozoic. This conclusion is based mainly on compilations of the paleomagnetic poles of the various plates. Morel and Irving (1981) propose that about 3500 $\mathrm{km}$ of movement occurred along a megashear zone between the early Permian and Early Jurassic (these are boundary ages; no compilation was made for Triassic positions), and that the Pangea super continent of the Permian had the northwest coast of South America next to the east coast of North America. Peinado et al. (1982) review the data base and conclude that either this fit or an alternate fit proposed by Van der Voo et al. (1976), in which the northwest coast of South America is against the Gulf coast of North America, is plausible. The tim- ing of the large movements between North America and Africa is constrained by recent Triassic and Jurassic paleomagnetic poles (Steiner, in press). An early phase of right-lateral movement occurred during the middle Triassic. Whether North America and Europe were coupled at this time is uncertain (Morel and Irvine, 1981).

Smith and Noltimier (1979) found that $9^{\circ}$ of apparent polar wander occurred relative to North America between 195 m.y. and 179 m.y. (radiometric ages on basalt flows and intrusives). Steiner (in press) obtained the same result by comparing pre-late Pliensbachian pole positions with those of early late Callovian. These two studies place limits on the timing of plate movement relative to stable Africa, if one uses the Jurassic absolute time scale of Armstrong (1978, in press). A plausible interpretation is that during the Pliensbachian and perhaps Toarcian-Aalenian, the North America-Europe block had considerable right-lateral (or counterclockwise) movement relative to Africa. This movement followed the Sinemurian-Pliensbachian initiation of rifting and subsidence observed on the margins of the Western Tethys, and coincided with the early phase of marine sedimentation on the Atlantic margins. The pole or rotation of this movement is constrained by the Callovian basement age at Site 534 and the observed tensional rifting of the Western Tethys, implying that the early "opening" phase of the Atlantic was dominated by a major right-lateral fault system, with hundreds of kilometers of movement during this interval. Perhaps this movement formed the Inner Magnetic Quiet Zone west of the Blake Spur Magnetic Anomaly.

There was no apparent polar wander of North America between the late Toarcian (179 Ma) and the Callovian (Steiner, in press), and probably North America-Africa were in the reconstructed Pangea fit positions of Le Pichon et al. (1977) or Sclater et al. (1977). Rapid polar wander occurred from the Oxfordian through the Late Jurassic (Steiner, in press). The results of Site 534 and recent dating of the early M-sequence of marine magnetic anomalies (Ogg, 1981b; Ogg and Steiner, unpublished data) indicate a Callovian-Oxfordian-Kimmeridgian spreading half rate of about $3.4 \mathrm{~cm} / \mathrm{yr}$. The projected age of the Blake Spur Ridge is latest Bathonian or early Callovian, which is probably the effective age of active seafloor spreading of the Atlantic. This projection agrees with the biogeographic constraints (Hallam, $1980)$ and with the circum-North Atlantic geological data (Jansa and Wade, 1975).

The relative motion of Africa and Europe was mainly left-lateral, with some compression toward the east. If the Italy-Greece block was a peninsula of Africa during the Jurassic, this movement would have created a wide oceanic seaway between Italy and Spain-southeastern France and closed the "Vardar" ocean between Greece and the present-day eastern Balkan. This closure was completed near the end of the Tithonian, as indicated by ophiolite debris; then the Western Tethys no longer had a deep-water connection to the Eastern Tethys.

As explained in the opening sections of this chapter, the reconstructed paleogeography of the Atlantic shows no significant deep-water connections to the Caribbean- 
Pacific existed prior to the latest Jurassic. Indeed, with the constriction of the "Vardar" connection, it is possible that there was no significant deep-water exchange with the Pacific "World Ocean" at either end of the Atlantic-Western Tethys seaway during most of the Late Jurassic.

\section{Fertility and Biogeneous Pelagic Sediments}

Radiolarian cherts were the main pelagic sediment of the Western Tethys during the Oxfordian and probably during the poorly dated Callovian as well. At Site 534, radiolarian-rich mudstone occurs in the Callovian above basal ?middle Callovian calcareous marls; the Oxfordian clays are barren of all bioclasts, perhaps because of silica dissolution during slow sedimentation or a reduced radiolarian influx.

Hsü (1976) proposed that the radiolarian chert episode in the Western Tethys was produced by high fertility of equatorial waters. However, the paleolatitude of the Western Tethys belt during the Late Jurassic is about 12 to $20^{\circ} \mathrm{N}$ and only the more southern location of Site 534 would be near the equatorial high-productivity zone, if the zonal wind and current system of the Jurassic resembled the present. Jenkyns and Winterer (1982) compare the Tethyan conditions to present semirestricted basins, such as the Gulf of California, where siliceous sediments are common. This model implies relatively high fertility.

Near the end of the Jurassic, there is a widespread transition from red marls to white limestone throughout the North Atlantic and Western Tethys. Speculative causes range from changes in spreading ridge activity or regional volcanic exhalations, reduced input of red tropical clays, reduction in bottom-water circulation, dilution by carbonate as the CCD dropped or coccolith productivity exploded, and a change in the oceanic iron cycle or chemistry (Ogg, 1981a).

At Site 534, the critical factor determining color is the ratio of Fe to organic matter of the sediment, in turn dependent on the clay to carbonate ratio. The increased input of carbonate, beginning in the Tithonian, is responsible for the change of color. There is no evidence for a change in bottom-water circulation or dissolved-oxygen level, nor a need to invoke such changes. Bioturbation actually increases as the sediments become more limerich and change color.

The red to white color transition is the main criteria for separating the Cat Gap and Blake-Bahama formations (Jansa et al., 1979). Because this change in the oxidation state of the iron will depend locally on the increasing ratio of carbonate deposition to clay deposition rate, the exact age will be variable. However, the increase in carbonate deposition rate appears to be a general phenomenon through the Atlantic-Western Tethys during the late Tithonian, so the age variation will be small. Magnetostratigraphic correlation of Site 534 places the red to white transition exactly midway between M-19 and M-18 (or at the base of Calpionellid Zone B), whereas the gradual transition in northern Italy (Trento Plateau) is placed between M-19 and M-20 (or the middle of Calpionellid Zone A) - a difference of about $1 \mathrm{~m}$.y. (Ogg, this volume).
Uppermost Tithonian-Lower Cretaceous, white, radiolarian-rich, pelagic limestones are a general feature of the Atlantic and Western Tethys. What caused the change from reddish "condensed" facies to white limestones? One theory is that there was a drop in the CCD that permitted an increase in carbonate deposition-preservation on the seafloor (Garrison and Fischer, 1969; Winterer and Bosellini, 1981). We have already noted the evidence for the sharp drop in the CCD-ACD levels during the Kimmeridgian at Site 534 and in the Western Tethys. However, in the upper Tithonian, there is evidence for a rise in the ACD. This is suggested by the disappearance of aragonite above Core 95 at Site 534 and the equivalent level at Site 391, the lack or sharply reduced abundance of ammonites in the white limestone overlying lower Tithonian "Ammonitico Rosso" red limestone of the Trento Plateau of the Southern Alps, and some sections in Sicily. Continued CCD deepening in the Tithonian is not consistent with an apparent rise in the ACD unless the ACD and CCD are uncoupled and move independently or in opposition, but this does not happen in the present ocean; the CCD-ACD rose in some places and fell in others, but this does not explain the coeval initiation of white limestones; or the ACD and CCD both rose slightly near the end of the Tithonian, and the CCD rise is not as well documented.

A second theory is that a rapid evolution of calcareous nannoplankton occurred, bringing about a dramatic increase in abundance; hence nannoplankton delivered more carbonate to the seafloor (Garrison and Fischer, 1969; Bosellini and Winterer, 1975). The "evolution", portion of this theory is inconsistent with the dearth of nannofossil events to subdivide the Tithonian; the "dramatic increase in abundance" appears to be valid and would imply an increase in productivity of nannoplankton.

The evidence points toward a net long-term increase in carbonate deposition on the ocean floor and submerged continental margins as carbonate deposition on the shelves declined during a relative fall in sea level. To support the high carbon productivity, fertility must have been maintained by active upwelling. High fertility is also indicated by the continued (though diluted) abundance of radiolarians in the white limestone.

\section{ACKNOWLEDGMENTS}

We would like to recognize the other sedimentologists and scientists of Legs 76 and the Leg 76 Extension who made all the basic observations and many of the interpretations incorporated in this chapter. A. Hallam and E. L. Winterer reviewed an early manuscript and made innumerable helpful comments. S. Orlofsky was instrumental in converting the manuscript with its extensive revisions into final form.

\section{REFERENCES}

Alvarez, W., 1976. A former continuation of the Alps. Geol. Soc. Am. Bull., 87:891-896.

Amato, R. V., and Bebout, J. W. (Eds.), 1980. Geologic and Operational Summary, COST No. G-1 Well, Georges Bank area, North Atlantic OCS. U.S. Geol. Surv. Open-File Rep. 80-268.

Amato, R. V., and Simonis, E. K. (Eds.), 1979. Geological and Operational Summary, COST No. B-3 Well, Baltimore Canyon Trough area, Mid-Atlantic OCS. U.S. Geol. Surv. Open-File Rep. 79-1159. (Eds.), 1980. Geologic and Operational Summary, COST NO. G-2 Well, Georges Bank Area, North Atlantic OCS. U.S. Geol. Surv. Open-File Rep. 80-289. 
Arkell, W. J., 1956. Jurassic Geology of the World: Edinburgh (Oliver and Boyd).

Armstrong, R. L., 1978. Pre-Cenozoic Phanerozoic time scale-computer file of critical dates and consequences of new and in-progress decay-constant revisions. Am. Assoc. Petrol. Geol., 6:73-91.

, in press. Late Triassic-Early Jurassic time scale calibration in British Columbia, Canada. In Odin, G. (Ed.), Numerical Dating in Stratigraphy: Chichester (John Wiley \& Sons).

Arthur, M. A., and Natland, J. H., 1979. Carbonaceous sediments in the North and South Atlantic: the role of salinity in stable stratification of Early Cretaceous basins. In Talwani, M., Hay, W., and Ryan, W. B. F. (Eds.), Deep Drilling Results in the Atlantic Ocean: Continental Margins and Paleoenvironment: Washington (Am. Geophys. Union), Maurice Ewing Series, 3:354-401.

Arthur, M. A., von Rad, U., Cornford, C., McCoy, F. W., and Sarnthein, M., 1979. Evolution and sedimentary history of the Cape Bojador continental margin, Northwestern Africa. In von Rad, U., Ryan, W. B. F., et al., Init. Repts. DSDP, 47, Pt. 1: Washington (U.S. Govt. Printing Office), 773-816.

Aubouin, J., Bonneau, M., Celet, P., Charvet, J., Clement, B., Degardin, J. M., Dercourt, J., Ferriere, J., Fleury, J. J., Guernet, C., Maillot, H., Mania, J. H., Mansy, J. L., Terry, J., Thiebault, P., Tsoflias, P., and Verriex, J. J., 1970. Contribution a la géologie des Hellénides: le Gavrova, le Pinde et la zone ophiolitique subpélagonienne. Ann. Soc. Geol. Nord, 90:277-306.

Azéma, J., Bourrouilh, R., Champetier, Y., Fourcade, E., and Rangheard, Y., 1974. Rapports stratigraphiques, paléogéographiques et structuraux entre la chaine Iberique. Bull. Soc. Geol. Fr., 16: $140-160$.

Baltuck, M., 1981. Mesozoic pelagic sedimentation in a Tethyan basin, Pindos Mountains, Greece [Ph.D. dissert.]. Scripps Institution of Oceanography, University of California at San Diego.

1982. Provenance and distribution of Tethyan pelagic and hemipelagic siliceous sediments, Pindos Mountains, Greece. Sediment. Geol., 31:63-88.

Barrett, T. J., 1979. Origin of bedded cherts overlying ophiolitic rocks in the Italian North Apennines, and implications of the ophiolite pelagic sediment sequences for seafloor processes [Ph.D. dissert.]. Oxford University, Oxford, England.

Barss, M. S., Bujak, J. P., and Williams, G. L., 1979. Palynological zonation and correlation of sixty-seven wells, Eastern Canada. Geol. Surv. Can. Pap. 78-24.

Barton, C. M., 1976. Mount Olympus, Greece: new light on an old window. J. Geol. Soc. London, 131:389-396.

Bathurst, R. G. C., 1975. Carbonate Sediments and Their Diagenesis. Developments in Sedimentology (Vol. 12, 2nd ed.): New York (Elsevier).

Baumgartner, P., and Bernoulli, D., 1976. Stratigraphy and radiolarian fauna in a Late Jurassic-Early Cretaceous section near Achladi (Evvois, Eastern Greece). Eclogae Geol. Helv., 69:601-626.

Benson, W. E., Sheridan, R. E., Enos, P., Freeman, T., Gradstein, F., Murdmaa, I. O., Pastouret, L., Schmidt, R. R., Stuermer, D. H., Weaver, F. M., and Worstell, P., 1978. Site 391. In Benson, W. E., Sheridan, R. E., et al., Init. Repts. DSDP, 44: Washington (U.S. Govt. Printing Office), 153-336.

Berger, W. H., and Winterer, E. L., 1974. Plate stratigraphy and the fluctuating carbonate line. In Hsü, K. J., and Jenkyns, H. C. (Eds.), Pelagic Sediments: On Land and Under the Sea. Spec. Publ. Int. Assoc. Sedimentol., 1:11-48.

Berner, R. A., 1969. Goethite stability and the origin of red beds. Geochim. Cosmochim. Acta, 33:267-273.

Bernoulli, D., 1971. Redeposited pelagic sediments in the Jurassic of the Central Mediterranean area. In Vegh-Neubrant, E. (Ed.), Colloque du Jurassique Mediterraneen, Ann. Inst. Geol. Publici. Hung., 54, Pt. 2:71-90.

1972. North Atlantic and Mediterranean Mesozoic facies: a comparison. In Hollister, C. D., Ewing, J. I., et al., Init. Repts. DSDP, 11: Washington (U.S. Govt. Printing Office), 801-871.

Bernoulli, D., Caron, C., Homewood, P., Kälin, O., and Van Stuijvenberg, J., 1979. Evolution of continental margins in the Alps. Schweiz. Mineral. Petrogr. Mitt., 59:165-170.

Bernoulli, D., and Jenkyns, H. C., 1974. Alpine, Mediterranean, and Central Atlantic Mesozoic facies in relation to the early evolution of the Tethys. In Dott, R. H., Jr., and Shaver, R. H. (Eds.), Modern and Ancient Geosynclinal Sedimentation. Soc. Econ. Paleontol. Mineral. Spec. Publ., 19:129-160.
Bernoulli, D., and Laubscher, H., 1972. The palinspastic problem of the Hellinides. Eclogae Geol. Helv., 65:107-118.

Bernoulli, D., and Renz, O., 1970. Jurassic carbonate facies and new ammonite faunas from Western Greece. Eclogae Geol. Helv., 63: 573-607.

Biju-Duval, B., Dercourt, J., and Le Pichon, X., 1977. From the Tethys Ocean to the Mediterranean Seas: a plate tectonic model of the evolution of the Western Alpine system. In Biju-Duval, B., and Montadert, L., (Eds.), Internat. Symp. on the Structural History of the Mediterranean Basins, Split (Yugoslavia), Oct. 25-29, 1976: Paris (Editions Technip), 143-164.

Birkenmajer, K., 1960. Geology of the Pieniny Klippen Belt of Poland. Jahrb. Geol. Bundesanst. Austria, 103:1-36.

1973. Tectonic control of sedimentation at the JurassicCretaceous boundary in the Pieniny Klippen Belt, Carpatheans. Colloque sur la Limité Jurassique-Crétace, Lyon, 1973, Mem. BRGM, 86:294-299.

Bismuth, H., Bonnefous, J., and Dufaure, P., 1967. Mesozoic microfacies of Tunesia. In Martin, L. (Ed.), Guidebook to the Geology and History of Tunisia. Petrol. Expl. Soc. Libya (9th Ann. Field Conf.), pp. 159-214.

Bonnefous, J., 1967. Jurassic stratigraphy of Tunesia: a tentative synthesis (Northern and Central Tunesia, Sahel, and Chotts areas). In Martin, L. (Ed.), Guidebook to the Geology and History of Tunisia. Petrol. Expl. Soc. Libya (9th Ann. Field Conf.), pp. 109-130.

Bosellini, A., 1973. Modello geodinamico e paleotettonico delle Alpi Meridionali durante il Giurassico-Cretacico: sue possibili applicazioni agli Appennini. In Accordi, B. (Ed.), Moderne Vedute sullo Geologia dell'Appennino, Feb. 16-18, 1973. (Accademia Nazionale dei Lincei), Estratto del Quaderno N., 183:163-207.

Bosellini, A., and Winterer, E. L., 1975. Pelagic limestones and radiolarites of the Tethyan Mesozoic: a genetic model. Geology, 3: 279-282.

Bostrom, K., 1973. The origin and fate of ferromagnanoans at active ridge sediments. Stockholm Contrib. Geol., 27:149-243. 1977. The origin and quantitative significance of submarine volcanic exhalations as a source of deep sea sediments. Geol. Soc. Am., Abstracts with Programs, 6:906.

Boström, K., Peterson, M. N. A., Joensuu, O., and Fisher, D. E., 1969. Aluminum-poor ferromanganoan sediments of active oceanic ridges. J. Geophys. Res., 74:3261-3270.

Bourbon, M., 1978. Mesozoic evolution of Western North Atlantic and North Tethyan margins: a comparison. In Benson, W. E., Sheridan, R. E., et al., Init. Repts. DSDP, 44: Washington (U.S. Govt. Printing Office), 949-969.

1980. Evolution d'un secteur de la marge nord-tethysienne en milieu pelagique: la zone briançonnais pres de Briançon entre le debut du Malm et l'Eocene inferieur [these de docteur de sciences naturelles]. Université Louis Pasteur, Paris, France.

Bourbon, M., Caron, J.-M., de Graciansky, P.-C., Lemoine, M., Megard-Galli, J., and Mercier, D., 1976. The Mesozoic evolution of the Western Alps: birth and development of a part of the spreading oceanic Tethys and of its European continental margin. In BijuDuval, B., Montadert, L. (Eds.), Int. Symp. on the Structural History of the Mediterranean Basins, Split (Yugoslavia), October 25-29, 1976: Paris (Editions Technip).

Bourbon, M., de Graciansky, P. C., Lemoine, M., Megard-Gelli, J., and Mercier, D., 1975. Platform carbonates and pelagic condensed sequences, Mesozoic of the Briançonnais Zone (French Alps). 9th Cong. Int. Sedimentol. Nice 1975, Excursion 5.

Bourrouilh, R., and Gorsline, D. S., 1979. Pre-Triassic fit and alpine tectonics of continental blocks in the Western Mediterranean. Geol. Soc. Am. Bull., Pt. 1, 90:1074-1083.

Brunn, J. H., 1976. L'arc concave Zabro-Taurique et les arcs convexes Taurique et Egéen: collision des arcs induits. Bull. Soc. Geol. Fr., 18:553-367.

Bryan, G. M., Markl, R. G., and Sheridan, R. E., 1980. IPOD site surveys in the Blake-Bahama Basin. Mar. Geol., 35:43-63.

Burollet, P. F., 1967. General geology of Tunisia. In Martin, L. (Ed.), Guidebook to the Geology and History of Tunisia. Petrol. Expl. Soc. Libya (9th Ann. Field Conf.), pp. 51-58.

Burollet, P. F., Mugniot, J. M., and Sweeney, P., 1978. The geology of the Pelagian block: the margins and basins off southern Tunisia and Tripolitania. In Nairn, A. E. M., Kanes, W. H., and Stehl, F. G. (Eds.), The Ocean Basins and Margins, The Western Mediterranean (Vol. 4B): New York (Plenum Press), 331-359. 
Busson, G., 1967. Mesozoic of southern Tunisia. In Martin, L. (Ed.), Guidebook to the Geology and History of Tunisia. Petrol. Expl. Soc. Libya (9th Ann. Field Conf.), pp. 131-152.

Cairé, A., 1974. Eastern Atlas. In Spencer, A. M. (Ed.), MesozoicCenozoic Belts, Data for Orogenic Studies. Geol. Soc. London Spec. Publ., 4:46-59.

1975. Italy in its Mediterranean setting. In Squyres, C. (Ed.), Geology of Italy: Tripoli (Earth Sci. Soc. of the Libyan Arab Republic), pp. 11-74.

Catalano, R., Channell, J. E. T., D'Argenio, B., and Napoleone, G., 1976. Mesozoic paleogeography of the Southern Apennines and Sicily. Mem. Soc. Geol. Ital., 15:95-118.

Channell, J. E. T., D'Argenio, B., and Horvath, F., 1979. Adria, the African promontory. Earth Sci. Rev., 15:213-292.

Channell, J. E. T., Catalano, R., and D'Argenio, 1980. Paleomagnetism and deformation of the Mesozoic continental margin in Sicily. Tectonophysics, 61:391-407.

Coleman, R. G., 1981. Tectonic setting for ophiolite obduction in Oman. J. Geophys. Res., 86:2497-2508.

Cotillon, P., 1971. Le Crétace inferieur de l'arc subalpin de Castellane entre l'Asse et le Var: stratigraphie et sédimentologie. Mem. $B R G M, 68: 1-313$.

da Rocha, R. B., 1976. Estudo Estratigráfico e Paleontológic do Jurássico do Algarve Ocidental: Lisbon (Univ. Nova do Lisbon).

da Rocha, R. B., and Marqués, B., 1979. Le Jurassique de l'Argarve (Portugal): Esquisse stratigraphique et évolution paléogéographique. Cuad. Geol. Univ. Granada, 10:35-43.

de Graciansky, P. C., Poag, C. W., et al., in press. Init. Repts. DSDP, 80: Washington (U.S. Govt. Printing Office).

Delaune-Mayer, M., 1978. Cherts Mésozoïque du bassin Téthysien oriental: minéralogie et géochemie des sédiments siliceau du secteur de Taminah (NW Syrien). Cah. ORSTOM Ser. Geol., 10: 191-202.

Delaune-Mayer, M., Marcoux, J., Parrot, J.-F., and Poisson, A., 1977. Modele d'évolution Mésozoique de la paleomarge Téthysienne au niveau des nappes radiolaritiques et ophiolitiques du Taurus Lycian., d'Antalya et du Baer-Bassit. In Biju-Duval, B., and Montadert, L. (Eds.), Internat. Symp. on the Structural History of the Mediterranean Basins, Split (Yugoslavia), Oct. 25-29, 1976: Paris (Editions Technip), 79-94.

Delaune-Mayer, M., and Parrot, J.-F., 1976. Evolution du Mésozoĩque de la marge continentale méridionale du bassin Téthysian oriental d'après l'étude des séries sédimentaires do la region ophiolitique du NW Syrien. Cah. ORSTOM Ser. Geol., 8:173-183.

Delaune-Mayer, M., and Saint-Marc, P., in press. Données stratigraphiques nouvelles sur les sédiments oceaniques Mésozoïques associés aux nappes ophiolitique du Baer-Bassit (N.W. Syrien). Cah. ORSTOM Ser. Geol., 11.

Dewey, J. F., Pitman, W. C., III, Ryan, W. B. F., and Bonnin, J., 1973. Plate tectonics and the evolution of the Alpine system. Geol. Soc. Am. Bull., 84:3137-3180.

Diersche, V., 1980. Die Radiolarite des Oberjura im Mittabschnitt er Nördlichen Kalkalpen. Geotekt. Forsch., 58:1-217.

Dillon, W. P., Paull, C. K., Buffler, R. T., and Fail, J.-P., 1979. Structure and development of the Southeast Georgia Embayment and northern Blake Plateau: preliminary analysis. In Watkins, J. S., Montadert, L., and Dickerson, P. W. (Eds.), Geological and Geophysical Investigation of Continental Margins. Am. Assoc. Pet. Geol. Mem., 29:27-41.

Donnelly, T. W., and Wallace, J. L., 1976a. Major element chemistry of the Tertiary rocks at Site 317 and the problem of the origin of the nonbiogenic fraction of pelagic sediments. In Schlanger, S. O., Jackson, F. D., et al., Init. Repts. DSDP, 33: Washington (U.S. Govt. Printing Office), 557-562.

,1976b. Major and minor element chemistry of Antarctic clay-rich sediments: Sites 322, 323, and 325, DSDP Leg 35. In Hollister, C. D., Craddock, C., et al., Init. Repts. DSDP, 35: Washington (U.S. Govt. Printing Office), 427-446.

Dumont, J. F., Gutnic, M., Marcoux, J., Monod, O., and Poisson, A., 1972. Les Trias des Taurides occidentales (Turquie). Définition du basin pamphylien: un nouveau domain à ophiolithes à la marge externe de la chaine taurique. Z. Dtsch. Geol. Ges., 123:385-409.
Durand Delga, M., 1967. Structure and geology of the northeast Atlas Mountains. In Martin, L. (Ed.), Guidebook to the Geology and History of Tunisia. Petrol. Expl. Soc. Libya (9th Ann. Field Conf.), pp. 59-83.

Ealey, P. J., and Knox, G. D., 1975. The Pre-Tertiary rocks of S.W. Cyprus. Geol. Mijnbouw, 54:85-100.

Eliuk, L. S., 1978. The Abenaki Formation, Nova Scotia Shelf, Canada - a depositional and diagenetic model for a Mesozoic carbonate platform. Bull. Can. Pet. Geol., 26:424-514.

Evans, I., and Kendall, C. G. St. C., 1977. An interpretation of the depositional setting of some deep-water Jurassic carbonates of the central High Atlas Mountains, Morocco. In Cook, H. E., and Enos, P. (Eds.), Deep-Water Carbonate Environments. Soc. Econ. Paleontol. Mineral. Spec. Publ., 25:249-261.

Flood, R. D., 1978. X-ray mineralogy of DSDP Legs 44 and 44A, western North Atlantic: lower continental rise hills, Blake Nose, and Blake-Bahama Basin. In Benson, W. E., Sheridan, R. E., et al., Init. Repts. DSDP, 44: Washington (U.S. Govt. Printing Office), 515-522.

Freeman, T., and Enos, P., 1978. Petrology of Upper Jurassic-Lower Cretaceous limestones, DSDP Site 391. In Benson, W. E., Sheridan, R. E., et al., Init. Repts. DSDP, 44: Washington (U.S. Govt. Printing Office), 463-475.

Freeman-Lynde, R. P., Cita, M. B., Jadoul, F., Miller, E. L., and Ryan, W. B. F., 1981. Marine geology of the Bahama Escarpment. Mar. Geol., 44:119-156.

Gaetani, M., 1975. Jurassic stratigraphy of the Southern Alps. In Squyres, C. (Ed.), Geology of Italy: Tripoli (Earth Sci. Soc. of the Libyan Arab Republic), pp. 377-402.

Garcia-Hernandez, M., Lopez-Garrido, A. C., Rivas, P., Sanz de Galdeano, C., and Vera, J. A., 1980. Mesozoic palaeogeographic evolution of the External Zones of the Betic Cordillera. Geol. Mijnbouw, 59:155-168.

Garrison, R. E., 1967. Pelagic limestones of the Oberalm Beds (Upper Jurassic-Lower Cretaceous), Austrian Alps. Bull. Can. Pet. Geol., 15:21-49.

Garrison, R. E., and Fischer, A. G., 1969. Deep-water limestones and radiolarites of the Alpine Jurassic. In Friedman, G. M. (Ed.), Depositional Environments in Carbonate Rocks, A Symposium. Soc. Econ. Paleontol. Mineral., Spec. Publ., 14:20-56.

Given, M. M., 1977. Mesozoic and early Cenozoic geology of offshore Nova Scotia. Bull. Can. Pet. Geol., 25:63-91.

Glennie, K. W., Boeuf, M. G. A., Hughes Clarke, M. W., MoodyStuart, M., Pilaar, W. F. H., and Reinhardt, B. M., 1973. Late Cretaceous nappes in the Oman Mountains and their geologic evolution. Am. Assoc. Pet. Geol. Bull., 57:5-27.

1974. Geology of Oman Mountains. K. N. G. Mijnbouwkd. Genoot. Verh., 31:1-423.

Graham, G., 1980a. Evolution of a passive margin and nappe emplacement in the Oman Mountains. In Panayiotou, E. A. (Ed.), Ophiolites. Proc. Int. Ophiolite Symposium, Cyprus, 1979, pp. 414-424. 1980b. Structure and sedimentology of the Hawasina window, Oman Mountains [Ph.D. dissert.]. The Open University, Bucks, England.

Grow, J. A., Mattick, R. E., and Schlee, J. S., 1979. Multichannel seismic depth sections and interval velocities over outer continental shelf and upper continental slope between Cape Hatteras and Cape Cod. In Watkins, J. S., Montadert, L., and Dickerson, P. W. (Eds.), Geological and Geophysical Investigation of Continental Margins. Am. Assoc. Pet. Geol. Mem., 29:65-83.

Habib, D., 1972. Dinoflagellate stratigraphy, Leg 11, Deep Sea Drilling Project. In Hollister, C. D., Ewing, J. I., et al., Init. Repts. DSDP, 11: Washington (U.S. Govt. Printing Office), 367-426.

Hallam, A., 1967. Sedimentology and paleogeographic significance of certain red limestones and associated beds in the Lias of the Alpine region. Scott. J. Geol., 3:195-220.

1975. Jurassic Environments: Cambridge (Cambridge University Press).

1978. Eustatic cycles in the Jurassic. Palaeogeogr. Palaeoclimatol. Palaeoecol., 23:1-32.

1980. A reassessment of the fit of Pangaea components and the time of their initial breakup. In Strangway, D. W. (Ed.), The 
Continental Crust and Its Mineral Deposits. Geol. Assoc. Can. Spec. Pap., 20:375-387.

Hallam, A., and Bradshaw, M. J., 1979. Bituminous shales and oolitic ironstones as indicators of transgressions and regressions. $J$. Geol. Soc. London, 136:157-164.

Heath, G. R., and Dymond, J., 1977. Genesis and transformation of metalliferous sediments from the East Pacific Rise, Bauer Deep, and Central Basin, northwest Nasca plate. Geol. Soc. Am. Bull., $88: 723-733$.

Hinkelbein, K., 1975. Beitrage zur Stratigraphie und Paläontologie des Juras von Ostspanien: VIII. Stratigraphie und Fazies im Mitteljura der zentralen Iberishchen Ketten (Contributions to the Stratigraphy and paleontology of the Jurassic in Eastern Spain: VIII. Stratigraphy and facies in the Middle Jurassic of the Central Iberian Range). Neues Jahrb. Geol. Palaeont. Abh., 148:139-184.

Hollister, C. D., Ewing. J. I., et al., 1972. Init. Repts. DSDP, 11: Washington (U.S. Govt. Printing Office).

Hsü, K. J., 1976. Paleoceanography of the Mesozoic Alpine Tethys. Geol. Soc. Am. Spec. Pap., 170.

1977. Tectonic evolution of the Mediterranean basins. In Nairn, A. E. M., Kanes, W. H., and Stehli, F. G. (Eds.), The Ocean Basins and Margins, The Eastern Mediterranean (Vol. 4A): New York (Plenum Press), 29-75.

Hynes, A J., Nisbet, E. G., Smith, A. G., Welland, M. J. P., and Rex, D. C., 1972. Spreading and emplacement ages of some ophiolites in the Othris region, Eastern Central Greece. Proc. 4th Aegaean Symp. Hanover, Z. Dtsch. Geol. Ges., 123:455-468.

Jansa, L. F., 1981. Mesozoic carbonate platforms and banks of the Eastern North American margin. Mar. Geol., 44:97-117.

Jansa, L. F., Enos, P., Tucholke, B. E., Gradstein, F. M., and Sheridan, R. E., 1979. Mesozoic-Cenozoic sedimentary formations of the North American Basin, western North Atlantic. In Talwani, M., Hay, W., and Ryan, W. B. F. (Eds.), Deep Drilling Results in the Atlantic Ocean: Continental Margins and Paleoenvironment: Washington (Am. Geophys. Union), Maurice Ewing Ser., 3:1-58.

Jansa, L. F., Gardner, J. V., and Dean, W. E., 1978. Mesozoic sequences of the Central North Atlantic. In Lancelot, Y., Seibold, E., et al., Init. Repts. DSDP, 41: Washington (U.S. Govt. Printing Office), 991-1031.

Jansa, L. F., and Wade, J. A., 1975. Geology of the continental margin off Nova Scotia and Newfoundland. In Van der Linden, W. J. M., and Wade, J. A. (Eds.), Offshore Geology of Eastern Canada Regional Geology (Pt. 2). Can. Geol. Surv. Pap., 74-30:51-106.

Jansa, L. F., and Wiedmann, J., 1982. Mesozoic-Cenozoic development of the Eastern North American and Northwest African continental margins: a comparison. In von Rad, U., Hinz, K., Sarnthein, M., and Seibold, E. (Eds.), Geology of the Northwest African Continental Margin: Berlin (Springer-Verlag), pp. 215-269.

Jefferies, R. P. S., and Minton, P., 1965. The mode of life of two Jurassic species of "Posidonia" (Bivalva). Paleontology, 8:156-185.

Jenkyns, H. C., 1970. The Jurassic of Western Sicily. In Alvarez, W., Gohrbandt, K. H. (Eds.), Geology and History of Sicily: Tripoli (Petroleum Exploration Society of Libya), pp. 245-254. 1971. The genesis of condensed sequences in the Tethyan Jurassic. Lethaia, 4:327-352.

1978. Pelagic environments. In Reading, H. G. (Ed.), Sedimentary Facies and Environments: New York (Elsevier), pp. 314-371.

1980a. Cretaceous anoxic events: from continents to oceans. J. Geol. Soc. London, 137:171-188. $107-118$

Jenkyns, H. C., and Winterer, E. L., 1982. Palaeo-oceanography of Mesozoic ribbon radiolarites. Earth Planet. Sci. Lett., 60:351-375.

Judkins, T. W., Simonis, E., and Heise, B. A., 1980. Correlation with other wells. In Amato, R. V., and Simonis, E. K. (Eds.), Geologic and Operational Summary COST NO. G-2 Well, Georges Bank Area, North Atlantic OCS. U.S. Geol. Surv. Open-File Rep. 80-289:33-36.

Juteau, T., 1975. Les ophiolites des nappes d'Antalya (Taurides occidentales, Turquie). Mem. Sciences Terre, 32.

Kälin, O., Patacca, E., and Renz, O., 1979. Jurassic pelagic deposits from southeastern Tuscany; aspects of sedimentation and new biostratigraphic data. Eclogae Geol. Helv., 72:715-762.
Kälin, O., and Trumpy, D. M., 1977. Sedimentation and Palaotektonik in den westlichen Sudalpen: Zur Triasisch-jurassischen Geschichte des Monte Nudo Beckens "Basin". Eclogae Geol. Helv., 70:295-350.

Kendall, C. G. St. C., and Schlager, W., 1981. Carbonates and relative changes in sea level. In Cita, M. B., and Ryan, W. B. F. (Eds.), Carbonate Platforms of the Passive-Type Continental Margins, Present and Past. Mar. Geol., 44:181-212.

Klitgord, K. D., and Behrendt, J. C., 1979. Basin structure of the U.S. Atlantic margin. In Watkins, J. S., Montadert, L., and Dickerson, P. W. (Eds.), Geological and Geophysical Investigation of Continental Margins. Am. Assoc. Pet. Geol. Mem., 29:85-112.

Krumbein, W. C., and Garrels, R. M., 1952. Origin and classification of chemical sediments in terms of $\mathrm{pH}$ and oxidation-reduction potentials. J. Geol., 60:1-33.

Kuhry, B., De Clercq, S. W. G., and Dekker, L., 1976. Indications of current action in Late Jurassic limestones, radiolarian limestone, Saccocoma limestones, and associated rocks from the Subbetic of SE Spain. Sediment. Geol., 15:235-258.

Kuznetsova, K. I., and Seibold, E., 1978. Foraminifers from the Upper Jurassic and Lower Cretaceous of the Eastern Atlantic (DSDP Leg 41, Sites 367 and 370). In Lancelot, Y., Seibold, E., et al., Init. Repts. DSDP, 41: Washington (U.S. Govt. Printing Office), 515-537.

Lancelot, Y., Hathaway, J. C., and Hollister, C. D., 1972. Lithology of sediments from the western North Atlantic. In Hollister, C. D., Ewing, J. I., et al., Init. Repts. DSDP, 11: Washington (U.S. Govt. Printing Office), 901-949.

Lancelot, Y., and Seibold, E., 1978. The evolution of the central Northeastern Atlantic-summary of results of DSDP Leg 41. In Lancelot, Y., Seibold, E., et al., Init. Repts. DSDP, 41: Washington (U.S. Govt. Printing Office), 1215-1245.

Lancelot, Y., Seibold, E., et al., 1978. Init. Repts. DSDP, 41: Washington (U.S. Govt. Printing Office).

Lancelot, Y. and Winterer, E. L., 1980. Evolution of the Moroccan oceanic basin and adjacent continental margin-a synthesis. In Lancelot, Y., Winterer, E. L., et al., Init. Repts. DSDP, 50: Washington (U.S. Govt. Printing Office), 801-821.

Lancelot, Y., Winterer, E. L., et al., 1980. Init. Repts. DSDP, 50: Washington (U.S. Govt. Printing Office).

Lapierre, H., 1975. Les formations sédimentaire et éruptives des nappes de Mamonia et leurs relations avec le Massif de Troodos (Chypre occidentale). Mem. Soc. Geol. Fr., 123:1-132.

Lapierre, H., and Rocci, G., 1976. Le volcanisme du sud-ouest de Chypre et le probleme de l'ouverture des region Tethysiennes au Trias. Tectonophysics, 30:299-313.

Larson, R. L., and Hilde, T. W. C., III, 1975. A revised time scale of magnetic reversals for the Early Cretaceous, Late Jurassic. J. Geophys. Res., 80:2586-2594.

Laubscher, H., and Bernoulli, D., 1977. Mediterranean and Tethys. In Nairn, A. E. M., Kanes, W. H., and Stehli, F. G. (Eds.), The Ocean Basins and Margins, The Eastern Mediterranean (Vol. 4A): New York (Plenum Press), 1-28.

Leinen, M., and Stakes, D., 1979. Metal accumulation rates in the central equatorial Pacific during Cenozoic time. Geol. Soc. Am. Bull., Pt. 1, 90:357-375.

Le Pichon, X., Sibuet, J.-C., and Francheteau, J., 1977. The fit of the continents around the North Atlantic Ocean. Tectonophysics, 38: 169-208.

Linares, A., and Vera, J. A. (Eds), 1979. El Jurasico de las Zonas Externas de las Cordilleras Beticas (II Coloquio de Estratigrafia y Paleogeografia del Jurasico de Espana, Granada, Oct. 1-6, 1979). Cuad. Geol. Univ. Granada, 10:353-651.

Lowrie, W., and Alvarez, W., 1975. Paleomagnetic evidence for the rotation of the Italian peninsula. J. Geophys. Res., 80:1579-1592.

Luterbacher, H., 1972. Foraminifers from the Lower Cretaceous and Upper Jurassic of the Northwestern Atlantic. In Hollister, C. D., Ewing, J. I., et al., Init. Repts. DSDP, 11: Washington (U.S. Govt. Printing Office), 561-594.

Marcoux, J., 1970. Age carnien des termes éffusives du cortège ophiolitique des Nappes d'Antalya (Taurus Lycien oriental, Turquie). $C$. R. Seances Acad. Sci. Paris, 271:285-287.

1974. Alpine type Triassic of the upper Antalya nappe (western Taurides, Turkey). In Zapfe, H. (Ed.), Die Stratigraphie 
der Alpin-Mediterranen Trias: Schriftenr. Erdwiss. Komm. Osterr. Akad. Wiss., 2:145-146.

1976. Les series triasiques des nappes a radiolarites et ophiolites d'Antalya (Turquie): homologies et signification probable. Bull. Soc. Geol. Fr., 18:511-512.

Mauritsch, H. J., and Frisch, W., 1978. Paleomagnetic data from the central part of the Northern Calcareous Alps, Austria. J. Geophys., 44:623-637.

1980. Paleomagnetic results from the Eastern Alps and their comparison with data from the Southern Alps and the Carpathians. Mitt. Osterr. Geol. Ges., 73:5-13.

McCave, I. N., 1979. Depositional features of organic-carbon-rich black and green mudstones at DSDP Sites 386 and 387, western North Atlantic. In Tucholke, B. E., Vogt, P. R., et al., Init. Repts. DSDP, 43: Washington (U.S. Govt. Printing Office), 411-416.

McIvor, N. L., 1972. Cenozoic and Mesozoic stratigraphy of the Nova Scotia shelf. Can. J. Earth Sci., 9:54-70.

McRae, S. G., 1972. Glauconite. Earth Sci. Rev., 8:397-440.

Mélières, F., 1978. X-ray mineralogy studies, Leg 41, Deep Sea Drilling Project, eastern North Atlantic Ocean. In Lancelot, Y., Seibold, E., et al, Init. Repts. DSDP, 41: Washington (U.S. Govt. Printing Office), 1065-1086.

Montadert, L., Roberts, D. G., DeCharpal, O., and Guennoc, P., 1979. Rifting and subsidence of the northern continental margin of the Bay of Biscay. In Montadert, L., Roberts, D. G., et al., Init. Repts. DSDP, 48: Washington (U.S. Govt. Printing Office), 1025-1060.

Morel, P., and Irving, E., 1981. Paleomagnetism and the evolution of Pangea. J. Geophys. Res., 86:1858-1872.

Murdmaa, I. O., 1978. Mesozoic variegated and red sediments of the Western North Atlantic, DSDP Legs 43 and 44. In Benson, W. E. Sheridan, R. E., et al., Init. Repts. DSDP, 44: Washington (U.S. Govt. Printing Office), 503-513.

Murdmaa, I. O., Gordeev, V. V., Bazilevskaya, E. S., and Emelyanov, E. M., 1978. Inorganic geochemistry of the Leg 44 sediments. In Benson, W. E., Sheridan, R. E., et al., Init. Repts. DSDP, 44: Washington (U.S. Govt. Printing Office), 575-582.

Norrish, K., and Hutton, J. T., 1969. An accurate X-ray spectographic method for the analysis of a wide range of geological samples. Geochim. Cosmochim. Acta, 33:431-454.

Odin, G. S., and Stephan, J. F., 1982. The occurrence of deep water glaucony from the Eastern Pacific: the result of in situ genesis or submergence?. In Watkins, J. S., Moore, J. C., et al., Init. Repts. $D S D P, 66$ : Washington (U.S. Govt. Printing Office), 419-428.

Oertli, H. J., 1972. Jurassic ostracods of DSDP Leg 11 (Sites 100 and 105)-preliminary account. In Hollister, C. D., Ewing, J. I., et al. Init. Repts. DSDP, 11: Washington (U.S. Govt. Printing Office), 645-668.

Ogg, J. G., 1979. Origins of pelagic nodular limestones. Geol. Soc. Am., Abstracts with Program, 11:489.

1981a. Middle and Upper Jurassic sedimentation history of the Trento Plateau (Northern Italy). In Farinacci, A., and Elmi, S. (Eds.), Rosso Ammonitico Symposium Proceedings: Rome (Edizioni Tecnoscienza), pp. 479-503.

1981b. Sedimentology and paleomagnetic studies of Jurassic pelagic limestones [Ph.D. dissert.]. Scripps Institution Oceanography, University of California, San Diego.

Parrot, J.-F., 1974. Le seceur de Tamimah (Tourkmannli): étude d'une séquence volcano-sédimentaire de la région ophiolitique du BaërBassit (Nord-ouest de la Syrie). Cah. ORSTOM Ser. Geol., 6: 127-146.

Patacca, I., Scandone, P., Giunta, G., and Liquori, V., 1979. Mesozoic paleotectonic evolution of the Ragusa Zone (Southeastern Sicily). Geol. Rom., 18:331-369.

Pearce, J. A., Alabaster, T., Shelton, A. W., and Searle, M. P., 1981. The Oman ophiolite as a Cretaceous arc-basin complex: evidence and implications. Philos. Trans. R. Soc. London Ser. A, 300: 299-317.

Peinado, J., Van der Voo, R., and Scotese, C., 1982. A reevaluation of Pangea reconstructions. EOS, 63:307.

Pitman, W. C., III, 1978. Relationship between sea-level change and stratigraphic sequences. Geol. Soc. Am. Bull., 89:1389-1403.

Pitman, W. C., III, and Talwani, M., 1972. Sea-floor spreading in the North Atlantic. Geol. Soc. Am. Bull., 83:619-649.
Poisson, A., 1978. Recherches géologiques dans las Taurides occidentales (Turquie) [these de docteur des sciences]. Université de ParisSud, Paris, France.

Price, I., 1977. Facies distinction and interpretation of primary cherts in a Mesozoic continental margin succession, Othris, Greece. Sediment. Geol., 18:321-335.

Purser, B. H. (Ed.), 1973. The Persian Gulf; Holocene Carbonate Sedimentation and Diagenesis in a Shallow Epicontinental Sea: Berlin-Heidelberg-New York (Springer).

Renz, O., Imlay, R., Lancelot, Y., and Ryan, W. B. F., 1975. Ammonite-rich Oxfordian limestones from the base of the continental slope off Northwest Africa. Eclogae Geol. Helv., 61:431-448.

Ricou, L. E., Argyriadis, I., and Lefevre, R., 1974. Proposition d'une origine interne pour les nappes d'Antalya et le massif d'Alanya (Taurides occidentales, Turquie). Bull. Soc. Geol. Fr., 18:107-111.

Ries, A., 1978. The opening of the Bay of Biscay-a review. Earth. Sci. Rev., 14:35-63.

Ríos, J. M., 1978. The Mediterranean coast of Spain and the Alboran Sea. In Nairn, A. E. M., Kanes, W. H., and Stehl, F. G. (Eds.), The Ocean Basins and Margins, The Western Mediterranean (Vol. 4B): New York (Plenum Press), 1-65.

Robertson, A. H. F., 1981. Metallogenesis on a Mesozoic passive continental margin, Antalya Complex, SW Turkey. Earth Planet. Sci. Lett., 54:323-345.

Robertson, A. H. F., and Stillman, C. J., 1979a. Late Mesozoic sedimentary rocks of Fuerteventura, Canary Islands. J. Geol. Soc. $136: 47-60$.

$1979 \mathrm{~b}$. Submarine volcanic and associated sedimentary rocks of the Fuerteventura Basal Complex, Canary Island. Geol. Mag., 116:203-314.

Robertson, A. H. F., and Woodcock, N. H., 1979. The Mamonia Complex, southwest Cyprus: the evolution and emplacement of a Mesozoic continental margin. Geol. Soc. Am. Bull., 90:651-665. 1980. Tectonic setting of the Troodos massif in the eas Mediterranean. In Paniotou, A. (Ed.), Ophiolites. Proc. Int. Ophiolite Symp., Cyprus, 1979, pp. 36-49.

1981a. Bilelyeri Group, Antalya Complex; deposition on a Mesozoic continental margin in SW Turkey. Sedimentology, 28: 381-401.

1981b. Alakir Cay Group, Antalya Complex, SW Turkey: a deformed Mesozoic carbonate margin. Sediment. Geol., 30: 95-131.

1981c. Gödene Zone, Antalya Complex. SW Turkey: volcanism and sedimentation on Mesozoic marginal ocean crust. Geol. Rundsch., 70:1177-1214.

Rocci, G., Baroz, F., Bebian, J., Desmet, A., Lapierre, H., Ohnenstetter, D., Ohnenstetter, M., and Parrot, J.-F., 1980. The Mediterranean ophiolites and their related Mesozoic volcano-sedimentary sequences. In Paniotou, A. (Ed.), Ophiolites. Proc. Int. Ophiolite Symp., Cyprus, 1979:273-287.

Ruget-Perrot, C., 1961. Etudes stratigraphiques sur le Dogger et le Malm inferieure du Portugal au Nord du Tage. Serviços Geológicos de Portugal Mem., 7 (nova série).

Salaj, J., 1978. The geology of the Pelagian block: the eastern Tunisian platform. In Nairn, A. E. M., Kanes, W. H., and Stehl, F. G. (Eds.), The Ocean Basins and Margins, The Western Mediterranean (Vol. 4B): New York (Plenum Press), 361-416.

Sander, N. J., 1970. Structural evolution of the Mediterranean region during the Mesozoic Era. In Alvarez, W. I., and Gohrbandt, K. H. A. (Eds.), Geology and History of Sicily: Tripoli (Petroleum Exploration Society of Libya), pp. 43-132.

Schlager, W., and Ginsburg, R. N., 1981. Bahama carbonate platforms-the deep and the past. In Cita, M. B., and Ryan, W. B. F. (Eds.), Carbonate Platforms of the Passive-Type Continental Margins, Present and Past. Mar. Geol., 44:1-24.

Schlanger, S. O., and Jenkyns, H. C. 1976. Cretaceous oceanic anoxic events: causes and consequences. Geol. Mijnbouw, 55:179-184.

Schlee, J. S., Behrend, J. C., Grow, J. A., Robb, J. M., Mattik, R. E., Taylor, P. T., and Lawson, B. J., 1976. Regional geologic framework off Northeastern United States. Am. Assoc. Pet. Geol. Bull., 60:926-951.

Schlee, J. S., and Jansa, L. F., 1981. The paleoenvironment and development of the eastern North American continental margin. Geology of Continental Margins Symposium (Proc. 26th Int. Geol. Cong., Paris, July 7-17, 1980). Oceanol. Acta, 1981:71-80. 
Scholle, P. A. (Ed.), 1977. Geological Studies on the COST No. B-2 Well, U.S. Mid-Atlantic Outer Continental Shelf Area. U.S. Geol. Surv. Circ. 750.

(Ed.), 1979. Geological Studies of the COST GE-1 Well, U.S. South Atlantic Continental Shelf Area. U.S. Geol. Surv. Circ. 800 .

Schott, J. J., Montigney, R., and Thuezat, R., 1981. Paleomagnetism and potassium-argon age of the Messejana Dike (Portugal and Spain): angular limitation to the rotation of the Iberian Peninsula Since the Middle Jurassic. Earth. Planet. Sci. Lett., 53:457-470.

Sclater, J., Anderson, R. N., and Bell, M. L., 1971. Elevation of ridges and evolution of the central Eastern Pacific. J. Geophys. Res., 76: 7888-7915.

Sclater, J., Boyle, E., and Edmond, J. M., 1979. A quantitative analysis of some factors affecting carbonate sedimentation in the oceans. In Talwani, M., Hay, W., and Ryan, W. B. F. (Eds.), Deep Drilling Results in the Atlantic Ocean: Continental Margins and Paleoenvironment: Washington (Am. Geophys. Union), Maurice Ewing Ser., 3:235-248.

Sclater, J. G., Hellinger, S., and Tapscott, C., 1977. The paleobathymetry of the Atlantic Ocean from the Jurassic to the present. $J$. Geol., 85:509-522.

Searle, M. P., Lippard, S. J., Smewing, F. D., and Rex, D. C., 1980. Volcanic rocks beneath the Semail Nappe in the northern Oman Mountains and their significance in the Mesozoic evolution of Tethys. J. Geol. Soc. London, 127:589-605.

Sengör, A. M. C., and Yilmaz, Y., 1981. Tethyan evolution of Turkey: a plate tectonic approach. Tectonophysics, 75:181-241.

Sheridan, R. E., Windisch, C. C., Ewing, J. I., and Stoffa, P. L., 1979. Stratigraphy and structure across the Blake Escarpment based on seismic reflection profiles. In Watkins, J. S., Montadert, L., and Dickerson, P. W. (Eds.), Geological and Geophysical Investigation of Continental Margins. Am. Assoc. Pet. Geol. Mem., 29:177-186.

Shipley, T. H., Buffler, R. T., and Watkins, J. S., 1978. Seismic stratigraphy and geologic history of the Blake Plateau and adjacent Western Atlantic continental margin. Am. Assoc. Pet. Geol. Bull., 62:792-812.

Sibuet, J.-C., and Ryan, W. B. F., 1979. Site 398: evolution of the West Iberian passive continental margin in the framework of the early evolution of the North Atlantic Ocean. In Ryan, W. B. F., Sibuet, J.-C., et al., Init. Repts. DSDP, 47, Pt. 2: Washington (U.S. Govt. Printing Office), 761-775.

Smith, A. G., Briden, J. C., and Drewery, G. E., 1973. Phanerozoic world maps. In Hughes, N. F. (Ed.), Organisms and Continents Through Time. Palaeontol. Spec. Pap., 12:1-42.

Smith, A. G., Hynes, A. J., Menzies, M. A., Nisbet, E. G., Price, L. Welland, M. J. P., and Ferriere, J., 1975. The stratigraphy of the Othris Mountains, eastern central Greece: a deformed Mesozoic continental margin sequence. Eclogae Geol. Helv., 68:463-481.

Smith, M. A., Amato, R. V. Furbush, M. A., Pert, D. M., Nelson, M. E., Hendrix, J. S., Tamm, L. C., Wood, G., Jr., and Shaw, D. R., 1976. Geological and Operational Summary, COST No. B-2 Well, Baltimore Canyon Trough Area, Mid-Atlantic OCS. U.S. Geol. Surv. Open-File Rep. 76-774.

Smith, T. E., and Noltimier, H. C., 1979. Paleomagnetism of the Newark trend igneous rocks of the North Central Appalachians and the opening of the Central Atlantic Ocean. Am. J. Sci., 279: 778-807.

Steiner, M. B., in press. Mesozoic plate motions of North America. In Mesozoic Paleogeography of the West-Central United States. Soc. Econ. Paleontol. Mineral. Spec. Publ.

Swarbrick, R. E., 1980. The Mamonia Complex of S.W. Cyprus: a Mesozoic continental margin and its relationship to the Troodos Massif. In Paniotou, A. (Ed.), Ophiolites. Proc. Int. Ophiolite Symp., Cyprus, 1979, pp. 86-93.

Swarbrick, R. E., and Robertson, A. H. F., 1980. Revised stratigraphy of Mesozoic rocks of southern Cyprus. Geol. Mag., 117: 547-563.
Trumpy, R., 1975. Penninic-Austroalpine boundary in the Swiss Alps: a presumed former continental margin and its problems. Am. J. Sci., 275-A:209-238.

Tucholke, B. E. and Vogt, P. R., 1979. Western North Atlantic: sediment evolution and aspects of tectonic history. In Tucholke, B. E., Vogt, P. R., et al., Init. Repts. DSDP, 43: Washington (U.S. Govt. Printing Office), 791-825.

Vail, P. R., Mitchum, R. M., Jr., Shipley, T. H., and Buffler, R., 1980. Unconformities of the North Atlantic. Phil. Trans. R. Soc. London Ser. A, 294:137-155.

Vail, P. R., Mitchum, R. M., Jr., and Thompson, S., III, 1977. Seismic stratigraphy and global changes of sea level, Part 4: Global cycles of relative changes of sea level. Am. Assoc. Petrol. Geol. Mem., 26:83-97.

Vail, P. R., and Todd, R. G., 1980. Northern North Sea Jurassic unconformities, chronostratigraphy and sea-level changes from seismic stratigraphy. Proc. Petroleum Geology of the Continental Shelf of Northwest Europe Conference, London, March 4-7, 1980.

Van de Fliert, J. R., Graven, H., Hermes, J. J., and De Smet, M. E. M., 1980. On stratigraphic anomalies associated with major transcurrent faulting. Eclogae Geol. Helv., 73:223-237.

Vandenberg, J., 1979a. Paleomagnetic data from the Western Mediterranean: a review. Geol. Mijnbouw, 58:161-174.

1979b. Reconstructions of the Western Mediterranean area for the Mesozoic and Tertiary timespan. Geol. Mijnbouw, 58: 153-160.

1980. New palaeomagnetic data from the Iberian Peninsula. Geol. Mijnbouw, 59:49-60.

Vandenberg, J., and Wonders, A. A. H., 1976. Paleomagnetic evidence of large fault displacement around the Po Basin. Tectonophysics, 33:301-320.

Van der Voo, R., Mauk, F. J., and French, R. B., 1976. Permian-Triassic continental configurations and the origin of the Gulf of Mexico. Geology, 4:177-180.

Van Hinte, J. E., 1976. A Jurassic time scale. Am. Assoc. Pet. Geol. Bull., 60:489-497.

Van Houten, F. B., 1977. Triassic-Liassic deposits of Morocco and eastern North America: comparison. Am. Assoc. Pet. Geol. Bull., 61:79-99.

Van Houten, F. B., and Brown, R. H., 1977. Latest Paleozoic-Early Mesozoic paleogeography, Northwestern Africa. J. Geol,, 85: 143-156.

Vera, J. A., Azéma, J., Foucault, A., Fourcade, E., Garcia-Hernandez, M., et al., 1979. Las Microfacies del Jurasico y Cretacio de las Zonas Externas de las Cordilleras Beticas Granade (Universidad de Granada).

Vogt, P. R., 1973. Early events in the opening of the North Atlantic. In Tarling, D. H., and Runcorn, S. K. (Eds.), Implications of Continental Drift to the Earth Sciences (Vol. 2): New York (Academic Press), 693-712.

Waldron, J. W. F., 1981. Mesozoic sedimentary and tectonic evolution of the northeast Antalya Complex, Egridir, S.W. Turkey [Ph.D. dissert.]. University of Edinburgh, Edinburgh, Scotland.

Williams, C., 1975. Seafloor spreading in the Bay of Biscay and its relationship to the North Atlantic. Earth Planet. Sci. Lett., 24: 440-456.

Wilson, J. L., 1975. Carbonate Facies in Geologic History: New York (Springer).

Winterer, E. L., and Bosellini, A., 1981. Subsidence and sedimentation on a Jurassic passive continental margin (Southern Alps, Italy). Am. Assoc. Pet. Geol. Bull., 65:394-421.

Woodcock, N. H., and Robertson, A. H. F., 1982. Geology of the Batinah Melange, Oman. Geol. Mag., 119:67-76.

Zemmels, I., Cook, H. E., and Hathaway, J. C., 1972. X-ray mineralogy studies. In Hollister, C. D., Ewing, J. I., et al., Init. Repts. $D S D P, 11$ : Washington (U.S. Govt. Printing Office), 729-790. 